\author{
UNIVERSIDADE DE SÃO PAULO \\ ESCOLA DE ENGENHARIA DE LORENA
}

WAGNER LUIZ DA COSTA FREITAS

ESTUDO DO EFEITO DE MICRORGANISMOS PROBIÓTICOS SOBRE

Eimeria acervulina (Tyzzer, 1929) EM FRANGOS DE CORTE.

$$
\text { Lorena - SP }
$$





\title{
ESTUDO DO EFEITO DE MICRORGANISMOS PROBIÓTICOS SOBRE Eimeria acervulina (Tyzzer, 1929) EM FRANGOS DE CORTE.
}

\begin{abstract}
Dissertação apresentada à Escola de Engenharia de Lorena da Universidade de São Paulo para a obtenção do título de Mestre em Ciências do programa de Pósgraduação em Biotecnologia Industrial, na área de Concentração: Microbiologia Aplicada.
\end{abstract}

Orientador: Dr. Ismael Maciel de Mancilha 
AUTORIZO A REPRODUÇÃO E DIVULGAÇÃO TOTAL OU PARCIAL DESTE TRABALHO, POR QUALQUER MEIO CONVENCIONAL OU ELETRÔNICO, PARA FINS DE ESTUDO E PESQUISA, DESDE QUE CITADA A FONTE.

\section{CATALOGAÇÃO NA PUBLICAÇÃO}

Biblioteca "Cel. Luiz Sylvio Teixeira Leite"

Escola de Engenharia de Lorena da Universidade de São Paulo

Freitas, Wagner Luiz da Costa

Estudo do efeito de microrganismos probióticos sobre Eimeria acervulina (Tyzzer, 1929) em frangos de corte. / Wagner Luiz da Costa Freitas. -ed. reimpr., corr.- 2011.

90 p. : il.

Dissertação (Mestre em Ciências - Programa de Pós-Graduação em Biotecnologia Industrial na Área de Microbiologia Aplicada) - Escola de Engenharia de Lorena da Universidade de São Paulo. 2011.

Orientador: Ismael Maciel de Mancilha

1. Probiótico 2. Lactobacillus 3. Eimeria acervulina. I. Título 
A minha família... pessoas que sempre vou amar... Mainha, Papai e Babinha (irmão), só tenho a agradecer pelo amor, carinho e educação que vocês sempre me deram. Este título eu dedico inteiramente a vocês. 



\section{AGRADECIMENTOS}

Primeiramente agradeço a Deus por esta conquista e por todas as oportunidades que tive durante minha vida, pela saúde, pela família que tanto tenho orgulho de ter e por sempre me dar forças para seguir em busca de novas conquistas.

A Nossa Senhora Desatadora dos Nós, a quem sou devoto, que sempre ouviu minhas preces e me ajudou a suportar as horas difíceis.

Em especial, agradeço ao meu pai, Wellington Luiz de Freitas, por ser um exemplo de homem e de pai, me oferecendo sempre educação, conselhos e meios de crescer sempre mais. A minha mãe, Maria de Fátima Costa Freitas, com seu amor incondicional por todos nós da família, fazendo até o impossível para nos manter felizes e de bem. Ao meu irmão, Fagner Luiz da Costa Freitas, meu melhor amigo e pessoa que respeito não só como um irmão mais velho, mas também como um pai. Muito obrigado por sempre estarem presentes e dispostos a ajudar, nunca medindo esforços para isso. Tenho orgulho de ter vocês como família e dedico esse trabalho a vocês.

À Katyane de Sousa Almeida, que sempre me deu conselhos e ajuda para conclusão desse trabalho.

Ao Professor Dr. Ismael Maciel de Mancilha a quem tenho um imenso sentimento de gratidão pela orientação oferecida, amizade e conselhos sugeridos. Sei que a vida é um aprendizado constante e esse período que estive sob sua orientação me fez crescer muito profissionalmente. Muito obrigado.

À professora Dra. Maria das Graças de Almeida Felipe, que me recebeu de braços abertos quando entrei no mestrado e que, mesmo estando bastante ocupada com os afazeres profissionais, sempre disponibilizava um momento para tirar dúvidas e aconselhar, fazendo isso sempre forma amigável e serena.

Ao professor Dr. Luiz Fernando Teixeira Albino, por toda ajuda e apoio oferecido durante a realização do meu experimento na UFV-MG.

Ao professor Dr. Carlos Alberto Sanches Pereira, pelos conselhos oferecidos em momentos de dúvidas durante o experimento.

À professora Urara Kawazoe, por ter cedido os parasitos para a realização do presente estudo e pela simpatia. 
Ao Bruno Carvalho, Dayse Yamagushi e Richard Costa pela grande ajuda oferecida para desenvolver o experimento e pela grande amizade criada. Muita saudade de todos vocês, muito obrigado por tudo que vocês fizeram por mim.

Ao meu amigo Valdeir Arantes, pela ajuda nos estudos durante a prova do mestrado.

Ao Guilherme Simões (o Tio), com quem dividi casa ao longo do mestrado, que sempre esteve como um grande amigo. Obrigado pelos conselhos e inúmeros momentos de felicidade. Tenho você como irmão.

À Karol e Deiler, amigos/irmãos que sempre vão estar em meu coração.

Ao Vinícius Fernandes, com quem também dividi casa durante boa parte do mestrado. Uma pessoa amiga com quem tive a honra de morar junto.

Ao meu amigo Flávio Ferraz, pela ajuda oferecida para contribuir com a qualidade do presente trabalho e pelos bons momentos cheios de risos e descontrações que pude ter com sua presença. Agradeço muito a você meu amigo.

À Stephanie Fraga, por toda ajuda, apoio e carinho durante o período de defesa e correção da dissertação. Muito obrigado pelos momentos felizes e especiais compartilhados.

À Marta Chagas (Martinha), por me ajudar a traduzir o resumo para o inglês, revisado minhas referências e por ter se tornado a grande amiga que sempre marca um momento com um sorriso no rosto e uma dose extra de simpatia.

À Júlia Fernandes (Jú), por ter se deslocado até a UNICAMP-SP para pegar meus parasitos e pela amizade, carinho e paciência por me aturar tanto tempo como vizinho.

À Lainy Garves, por ter se deslocado até Viçosa-MG para entregar a amostra dos parasitos em segurança.

À Regina Horta, por toda ajuda para finalização desse trabalho, sempre com um sorriso e muita simpatia.

À Sandra Cristina, Ana Beatriz e Maria Aparecida pela força, amizade, compreensão, puxões de orelha (rs) e por sempre me receberem com muita simpatia na CPG.

Aos meus amigos de laboratório e de departamento da EEL-USP e a todos os funcionários e amigos da UFV-MG que contribuíram com esse trabalho. 


\section{BIOGRAFIA}

Wagner Luiz da Costa Freitas, filho de Wellington Luiz de Freitas e Maria de Fátima Costa Freitas, nasceu em 13 de outubro de 1986, em Patos, Paraíba.

Em fevereiro de 2005, iniciou o curso de Ciências Biológicas na Faculdade São Luís em Jaboticabal-SP. Realizou estágio na Universidade Estadual Paulista - Campus Jaboticabal-SP, onde participou de trabalhos referentes à área de Parasitologia Animal. Em dezembro de 2007 graduou-se e recebeu o título de Licenciatura em Ciências Biológicas.

Em março de 2009, ingressou no programa de Pós-Graduação, em nível de mestrado, em Biotecnologia Industrial da Escola de Engenharia de Lorena - Universidade de São Paulo, com ênfase em Microbiologia Aplicada. Focou seus estudos na avaliação de uma preparação probiótica no combate a Eimeria acervulina, um parasito intestinal em frangos de corte. 



\section{RESUMO}

FREITAS, W. L. C. Estudo do efeito de microrganismos probióticos sobre Eimeria acervulina (Tyzzer, 1929) em frangos de corte. 2011. 90p. Dissertação (Mestrado em Ciências) - Escola de Engenharia de Lorena, Universidade de São Paulo, 2011.

No presente trabalho avaliou-se o efeito antiparasitário de uma preparação probiótica constituída por quatro espécies de lactobacilos, L. casei ATCC 7469, L. plantarum ATCC 8014, L. fermentum ATCC 9338 e L. acidophillus ATCC 4536, no tratamento da eimeriose aviária causada por Eimeria acervulina. Para tanto, foram utilizados 120 animais, da espécie Gallus gallus, machos, com 14 dias de idade, distribuídos em seis grupos, sendo o Grupo 1 constituído por animais tratados apenas com água e ração (controle negativo); Grupo 2 constituído por animais que receberam diariamente uma dose da preparação probiótica contendo $1 \times 10^{8} \mathrm{UFC} / \mathrm{mL}$; Grupo 3 constituído por animais infectados experimentalmente com $2 \times 10^{5}$ oocistos esporulados de Eimeria acervulina (controle positivo) e Grupo 4 onde os animais receberam diariamente uma dose da preparação probiótica contendo $1 \times 10^{8}$ UFC/mL durante o período do experimento e após 7 dias do início do tratamento, foram infectados com $2 \times 10^{5}$ oocistos esporulados de E. acervulina; no Grupo 5 os animais foram infectados com $2 \times 10^{5}$ oocistos esporulados de E. acervulina e paralelamente receberam uma dose diária da preparação probiótica em estudo contendo $1 \times 10^{8} \mathrm{UFC} / \mathrm{mL}$; no Grupo 6 os animais foram infectados com $2 \times 10^{5}$ oocistos esporulados de E. acervulina e após o surgimento dos sinais clínicos da infecção passaram a receber diariamente uma dose da preparação probiótica contendo $1 \times 10^{8} \mathrm{UFC} / \mathrm{mL}$, até o final do experimento. Durante 28 dias, semanalmente, amostras de sangue e fezes foram coletadas para determinação de OoPG, testes bioquímicos e parâmetros zootécnicos. Exames de fezes foram realizados diariamente para se determinar os períodos pré-patente e patente do parasita, bem como o efeito da preparação probiótica no combate a infecção. Os resultados demonstraram que a preparação probiótica em estudo reduziu a infecção intestinal causada por Eimeria acervulina, contribuindo para o bem estar animal. Referente aos parâmetros bioquímicos verificou-se efeito significativo sobre o perfil lipídico no $4^{\circ}$ dia pós infecção, não sendo observado diferenças significativas para os demais parâmetros. No tocante ao desempenho zootécnico, verificou-se que a preparação probiótica não resultou em diferenças significativas em relação ao ganho de peso, eficiência e conversão alimentar dos animais avaliados.

Palavras-chave: Probiótico; Lactobacillus spp; Eimeria acervulina; Frangos de corte. 


\begin{abstract}
FREITAS, W. L. C. Study of the effect of probiotic microorganisms on Eimeria acervulina (Tyzzer, 1929) in broilers. 2011. 90p. Dissertation (Master of Science) - Escola de Engenharia de Lorena, Universidade de São Paulo, 2011.

This study evaluated the antiparasitic effect of a probiotic preparation which consisted of four species of lactobacilli (Lactobacillus casei ATCC 7469, L. plantarum ATCC 8014, L. fermentum ATCC 9338 and L. acidophilus ATCC 4536) in the treatment of eimeriosis in broilers caused by Eimeria acervulina. Therefore, during 28 days, 120 animals of Gallus gallus species, males, 14 days old, were distributed in six groups, as follow: Group 1 the animals received only feed and water "ad libidum” (negative control); Group 2 consisted of animals that received a daily dose of probiotic preparation which contained $1 \times 10^{8} \mathrm{CFU} / \mathrm{mL}$; Group 3 the animals were experimentally infected with $2 \times 10^{5}$ oocysts of Eimeria acervulina (positive control); Group 4 the birds received a daily dose of probiotic preparation containing $1 \times 10^{8} \mathrm{CFU} / \mathrm{mL}$ during the experiment and after 7 days of the treatment beginning, these animals were infected with $2 \times 10^{5}$ oocysts of E. acervulina; Group 5 was composed by animals that were infected with $2 \times 10^{5}$ oocysts of the parasite and simultaneously received a daily dose of probiotic preparation containing $1 \times 10^{8} \mathrm{CFU} / \mathrm{ml}$, Group 6 the animals were infected with $2 \times 10^{5}$ oocysts of E. acervulina and after clinical signs of infection were noticed, the birds were treated daily with a dose of the probiotic preparation containing $1 \times 10^{8} \mathrm{CFU} / \mathrm{mL}$ until the end of the experiment. During 28 days six blood and feces samples were collected and parameters such as oocyst elimination, histopathological, and biochemical were evaluated. Stool examinations were performed daily to determine the parasite prepatent and patent periods, and the probiotic effect on the infection. The results showed that the probiotic preparation under study reduced the intestinal infection caused by Eimeria acervulina, contributing to animal welfare. Regarding the biochemical parameters there was a significant effect on the lipid profile on the $4^{\text {th }}$ day after infection, and no significant differences were observed for the other parameters. With regard to zootechnical performance, it was found that the probiotic preparation resulted in no significant differences in weight gain, and in feed conversion efficiency.
\end{abstract}

Keywords: Probiotic; Lactobacillus spp.; Eimeria acervulina; Broilers. 


\section{LISTA DE ILUSTRAÇÕES}

Figura 1: Morfologia das espécies de Eimeria causadoras de coccidiose em aves.

Figura 2 - Ciclo de vida da Eimeria spp.

Figura 3 - Mecanismo de infecção pelo trofozoíto e formação do vacúolo parasitóforo. 25

Figura 4 - Desenvolvimento dos merozoítos no Esquizonte. .26

Figura 5 - Presença de microgametócito e macrogametócito no tecido. .26

Figura 6 - Trato gastrointestinal de uma ave infectada com Eimeria acervulina. .28

Figuras 7 - Gaiolas contendo os diferentes grupos de aves...... .43

Figura 8 - Coleta de sangue, via intra-cardiaca.

Figura 9 - Pesagem das aves para avaliação do desempenho zootécnico. .46

Figura 10 - Contagem de oocistos por grama de fezes em frangos de corte, linhagem Cobb, infectados experimentalmente com oocistos esporulados de Eimeria acervulina e submetidos ao tratamento com preparação probiótica composta por 4 cepas de Lactobacillus spp....... . .48

Figura 11 - Microscopia do epitélio intestinal em frangos de corte, linhagem Cobb, infectados experimentalmente com oocistos esporulados de Eimeria acervulina e submetidos ao tratamento com preparação probiótica composta por 4 cepas de Lactobacillus spp. .52

Figura 12 - Média do peso vivo em frangos de corte, linhagem Cobb, infectados experimentalmente com oocistos esporulados de Eimeria acervulina e submetidos a diferentes tratamentos com preparação probiótica de Lactobacillus spp.

Figura 13 - Média do peso morto em frangos de corte, linhagem Cobb, infectados experimentalmente com oocistos esporulados de Eimeria acervulina e submetidos a diferentes tratamentos com preparação probiótica de Lactobacillus spp. .60 


\section{LISTA DE TABELAS}

Tabela 1- Parâmetros bioquímicos em frangos de corte, linhagem Cobb, infectados experimentalmente com oocistos esporulados de Eimeria acervulina e submetidos ao tratamento com preparação probiótica composta por 4 cepas de Lactobacillus

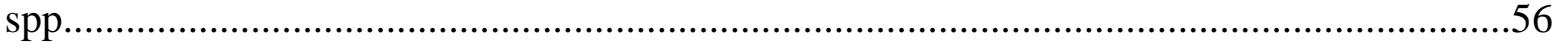

Tabela 2 - Rendimento de carcaça de frangos de corte, linhagem Cobb, aos 21 e 42 dias de vida, infectados experimentalmente com oocistos esporulados de Eimeria acervulina e submetidos ao tratamento com preparação probiótica de Lactobacillus spp. 61

Tabela 3 - Desempenho zootécnico de frangos de corte, linhagem Cobb, com 42 dias de vida, infectados experimentalmente com oocistos esporulados de Eimeria acervulina e submetidos a diferentes tratamentos com preparação probiótica de Lactobacillus

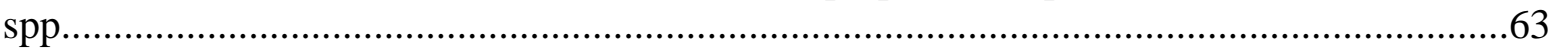




\section{SUMÁRIO}

1 INTRODUÇÃ O

2 REVISÃO DE LITERATURA ….......................................................................17

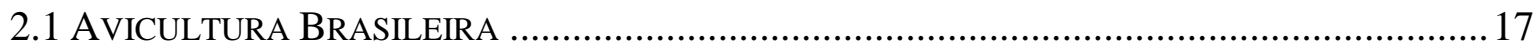

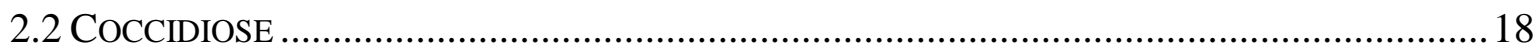

2.2.1 Coccidiose e a absorção de nutrientes .................................................................... 19

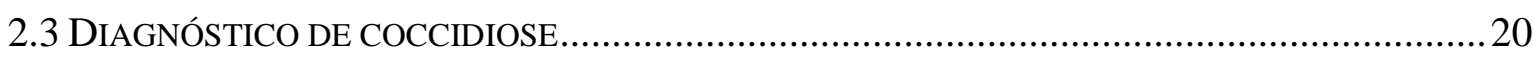

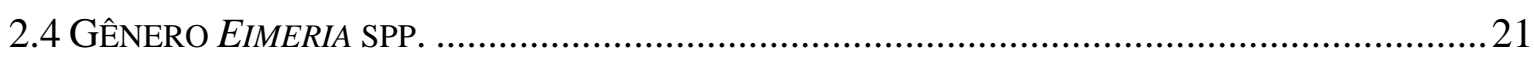

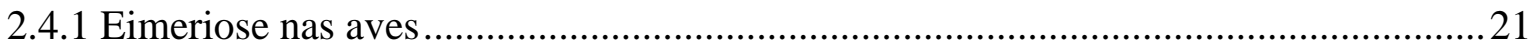

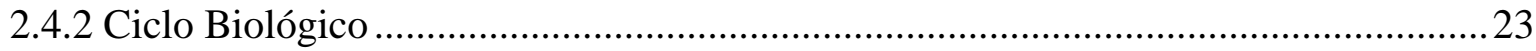

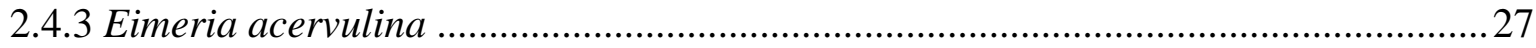

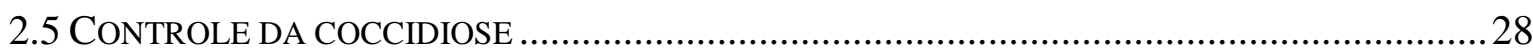

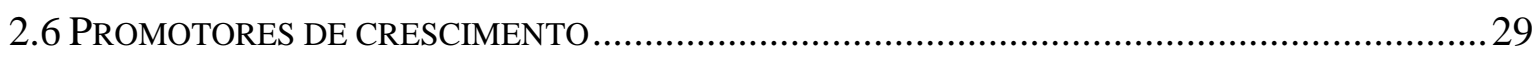

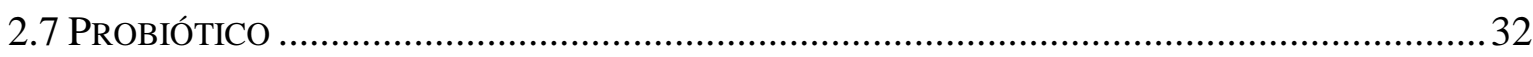

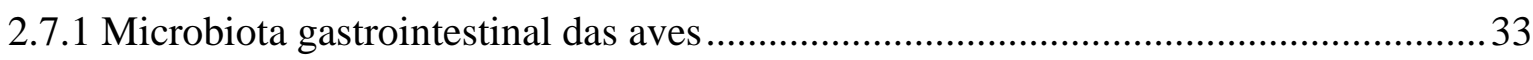

2.7.2 Mecanismo de ação dos probióticos ..........................................................................34

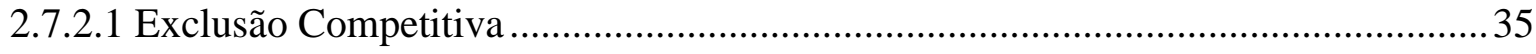

2.7.2.2 Produção de substâncias antibacterianas ...................................................................36

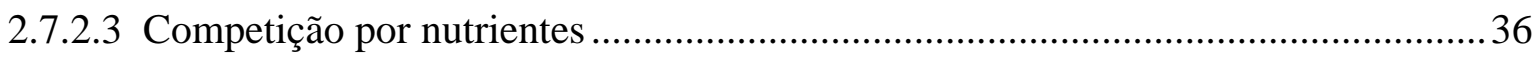

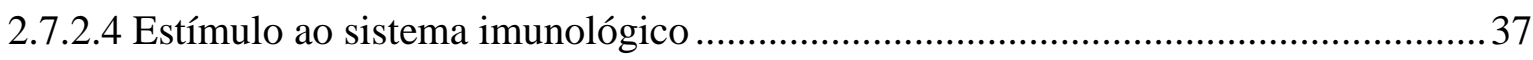

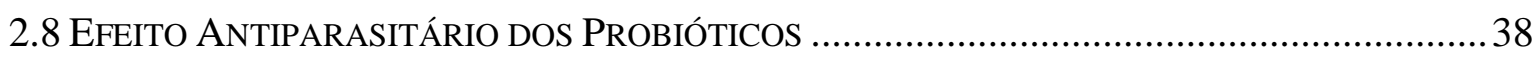

3 MATERIAL E MÉTODOS. ................................................................................41

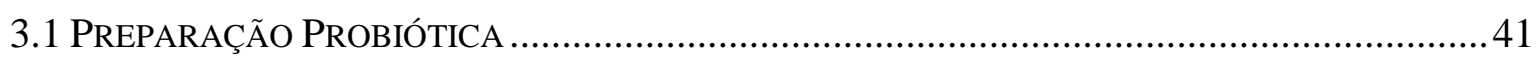

3.2 CEPAS DE EIMERIA ACERVULINA............................................................................ 42

3.3 DELINEAMENTO EXPERIMENTAL ........................................................................... 42

3.4 COLETA DE MATERIAL PARA ANÁLISE. ...................................................................... 43

3.4.1 Contagem de oocistos de Eimeria acervulina nas fezes ............................................... 43

3.4.2 Exames Histopatológicos................................................................................... 44

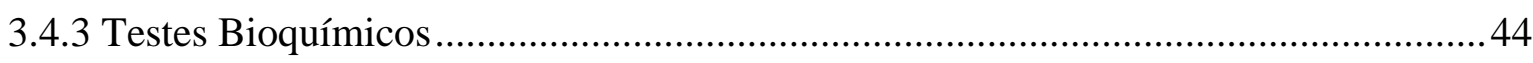

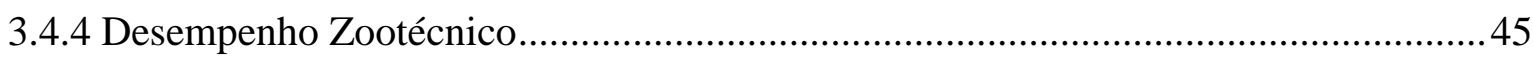

3.4.5 Análise estatística ……………………………………………………………..... 46 
4 RESULTADOS E DISCUSSÃO

.47

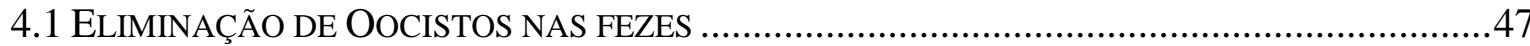

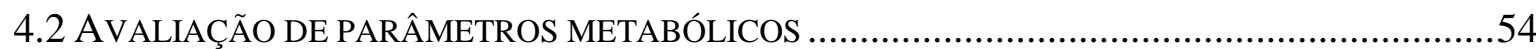

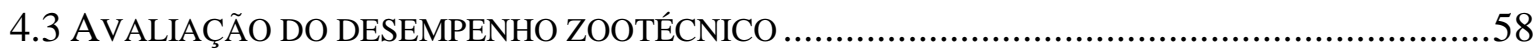

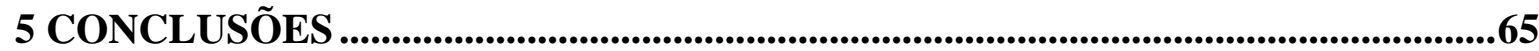

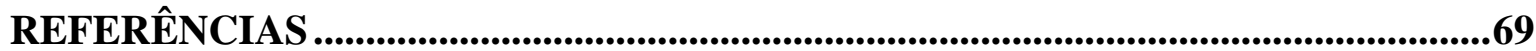

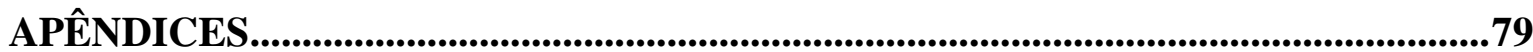




\section{INTRODUÇÃO}

A avicultura industrial brasileira apresentou um crescimento contínuo ao longo dos anos, constituindo-se de uma atividade de suma importância para a economia do país. Em 2001, a produção brasileira de frangos de corte foi de 6,736 milhões de toneladas e elevouse para 7,517 milhões de tonelada em 2002. Em 2006, segundo a Associação Brasileira dos Produtores e Exportadores de Frango - ABEF, a produção brasileira de carne de frango conquistou a marca dos 9,33 milhões de toneladas, sendo destas, 2,71 milhões de toneladas exportadas. No ano de 2007 a produção brasileira de carne de frango chegou a 9,7 milhões de toneladas. Em 2010 produção de frango somou 12,230 milhões de toneladas (ABEF, 2011; BRAZILIANCHICKEN, 2011).

No setor de exportações, em 2004 o Brasil conquistou a liderança mundial no ramo de exportação de carne de frango, ultrapassando os Estados Unidos, país que atualmente ocupa a liderança mundial na produção de frangos de corte. Em 2009, o Brasil exportou 3,6 milhões de toneladas, havendo um aumento de 5\% no ano de 2010, totalizando 3,810 milhões de toneladas embarcadas para mais de 150 países (ABEF, 2011; UBABEF, 2011; ABEF, 2009). Essa produtividade se deve, principalmente, as grandes transformações ocorridas na avicultura nas últimas décadas, caracterizando-se por seu alto grau de competitividade e avançados padrões tecnológicos.

A tecnologia empregada no setor avícola tem procurado otimizar a produção para atingir melhores resultados econômicos e produzir alimentos mais seguros e saudáveis para o consumidor. Neste sentido, a avicultura apresenta um desenvolvimento considerável devido aos avanços em áreas como genética, nutrição, manejo e sanidade. Em contrapartida a intensificação da produção pode acarretar um aumento da incidência de carga microbiana patógena, debilitando as aves, infectando um grande número de animais e, desta forma, reduzindo o desempenho zootécnico dos frangos de corte.

Entre os fatores limitantes da produção de frangos, a coccidiose é um dos mais importantes, acarretando grandes prejuízos na produção de aves de corte, sendo causada por protozoários do gênero Eimeria spp., tendo sete espécies reconhecidas em frangos de corte. Dentre estas, 3 espécies apresentam importância econômica para a avicultura, causando prejuízos às aves ao se multiplicarem nas células intestinais, ocasionando má absorção de nutrientes, desidratação, perda de sangue e aumento da susceptibilidade para 
outros agentes. No Brasil, em 1994, a perda anual por coccidiose, na produção de frangos de corte, representou US\$ 19 milhões, e atingiu 65\% das empresas do setor, apesar da adição preventiva e contínua de medicamentos anticoccidianos na ração dos frangos do primeiro dia ate 5 a 7 dias antes do abate. Em 2003, essas perdas representaram US\$ 60 milhões, sendo que no ano de 2007 os prejuízos causados por infecções causadas pelo gênero Eimeria spp. acarretou prejuízos anuais da ordem de US\$1 bilhão para avicultura mundial (CASTRO, 1994; BRITO, 2003; BIOVET, 2011).

Visando conferir benefícios à saúde animal, produtos com propriedades probióticas estão cada vez mais presentes na dieta animal. O termo probiótico foi proposto pela primeira vez em 1965 e consiste de um "suplemento alimentar composto de cultura pura ou composta de microrganismos vivos com a capacidade de se instalar e proliferar no trato intestinal, com ação de promotores de crescimento, beneficiando a saúde do hospedeiro pelo estímulo às propriedades existentes na microbiota natural". Sendo assim, animais tratados com probióticos podem ser mais resistentes a infecções por endoparasitos sendo que a evolução para a cura pode ser mais rápida acarretando em redução nos custos e melhorias na qualidade de vida e desempenho zootécnico dos animais, gerando assim uma maior lucratividade para o setor avícola.

Visando estudar o efeito antiparasitário de cepas de microrganismos probióticos, o presente trabalho teve como objetivo avaliar a eficácia de uma preparação probiótica constituída de um pool de $1 \times 10^{8} \mathrm{UFC} / \mathrm{mL}$ formado por 4 cepas de Lactobacilos sobre o controle da eimeriose causada por Eimeria acervulina em frangos de corte. 


\section{REVISÃO DE LITERATURA}

\subsection{AVICULTURA BRASILEIRA}

A avicultura brasileira destaca-se como um dos setores industriais mais globalizados da economia, sendo considerado exemplo de atividade agrícola e de cadeia produtiva de sucesso (ALBINO, 2008). No Brasil a produção de carne de frango chegou a 12,230 milhões de toneladas em 2010, em um crescimento de $11,38 \%$ em relação a 2009 , quando foram produzidas 10,980 milhões de toneladas. Com este desempenho o Brasil, atualmente terceiro maior produtor mundial, se aproxima da China que hoje é o segundo maior produtor mundial, cuja produção de 2010 teria somado 12,550 milhões de toneladas, abaixo apenas dos Estados Unidos, com 16,648 milhões de toneladas, conforme projeções do Departamento de Agricultura dos EUA (UBABEF, 2011).

Do total de frangos produzido pelo país, 69\% tem sido destinado ao consumo interno, e 31\% para exportações. O crescimento em 2010 foi impulsionado principalmente pelo aumento de consumo de carne de frango e pela expansão nas exportações. Os embarques de 3,819 milhões de toneladas em 2010 representaram um aumento de 5,1\% em relação a 2009, em novo recorde histórico para a carne de frango, principal produto das exportações avícolas brasileiras. No tocante a receita cambial, de US\$ 6,808 milhões, observou-se um incremento de 17\% (UBABEF, 2011).

Segundo a UBABEF (2011), em 2010, entre os principais importadores, o Oriente Médio importou 1,365 milhão de tonelada, gerando uma receita cambial de US\$ 2,233 bilhões, sendo observado um crescimento de 13\%. Para a Ásia as exportações foram de 1,008 milhão de toneladas, gerando uma receita de US\$ 1,920 bilhão, tendo um crescimento de $26,4 \%$, apresentando $6,5 \%$ superior ao verificado no ano anterior, A África representa o terceiro maior mercado de destino correspondendo a 495,3 mil toneladas $(+17,4 \%)$ e uma receita cambial de US\$ 610,5 milhões, tendo sido observado um crescimento de 3,8\%. A União Europeia respondeu por importação de 471,3 mil toneladas, sendo 7,2\% menor que em 2009, correspondendo a uma receita cambial, de US\$1,2 bilhão, sendo 1,8\% inferior à do ano anterior. No que se refere aos países das Américas o Brasil exportou 283,1 mil toneladas de carne de frango, $8 \%$ a mais em relação ao ano anterior, obtendo uma receita de US\$ 476,8 milhões. 
Ordenados segundo o conceito da receita cambial, dos cinco maiores importadores de carne de frango, nos meses decorridos entre Janeiro a Julho de 2011, o Japão ocupa a primeira opção, assumindo a liderança e gerando US\$ 659 milhões, seguido pela Arábia Saudita com US\$ 583,7 milhões, mesmo a Arábia Saudita apresentando um volume importado superior, com 296,9 mil toneladas contra 224,6 mil toneladas do Japão. Ocupando a terceira posição encontra-se Holanda, gerando US\$ 397,9 milhões, com volume de 119,1 mil toneladas. Hong Kong gerou US\$ 256,8 milhões para a receita cambial brasileira, importando um volume de 159,9 mil toneladas. Em quinto, encontra-se os Emirados Árabes gerando uma receita de US\$221,6 milhões, importando um volume de 112,9 mil toneladas (AVISITE, 2011).

\subsection{COCCIDIOSE}

O desenvolvimento tecnológico empregado na avicultura industrial melhorou sobremaneira os índices de conversão alimentar e precocidade das aves ao abate (LUCHESE, 2007). Por outro lado, as doenças entéricas tornaram-se um dos maiores desafios para a avicultura industrial mundial nos últimos anos devido a perdas de produtividade e ao aumento de mortalidade (SANTOS, 2005).

As perdas econômicas envolvendo a coccidiose são decorrentes ou da mortalidade dos animais infectados com alta carga parasitária ou devido o desempenho insatisfatório dos animais, incluindo a coccidiose entre as doenças responsáveis pelos maiores prejuízos causados à criação de ruminantes (LIMA, 2004).

A coccidiose é causada por protozoários do gênero Eimeria, sendo considerada a doença mais importante na avicultura industrial. Os agentes causadores da coccidiose são parasitos intracelulares que multiplicam-se no intestino, causando destruição tecidual e prejudicando a digestão e a absorção dos alimentos, o que resulta em diarréia aquosa ou hemorrágica (KAWASOE, 2000). O agente causa enterite e diarreia, dessa forma prejudicando a ingestão de ração, sua digestão e absorção intestinal de nutrientes e o transporte destes na corrente sanguínea, fatos que prejudicam o ganho de peso do animal (ALLEN, 2002; Anuário da Avicultura Industrial, 2000).

Allem (2002) relata que os sinais clínicos da coccidiose variam conforme as espécies de coccídios envolvidos na infecção. Algumas espécies apresentam maior grau de patogenicidade, causando diarréia que varia de mucóide a sanguinolenta, desidratação, 
penas arrepiadas, anemia, despigmentação da pele e prostração, dentre outros sinais clínicos.

Segundo Kawazoe (2000), Infecções oriundas de agentes coccidianos causam uma modificação nas estruturas das vilosidades intestinais provocando o encurtamento na altura das mesmas, diminuindo a capacidade de absorção. Muitas vezes ocorre a destruição das células epiteliais do intestino, impedindo a renovação das vilosidades levando a perda de fluidos, hemorragia e susceptibilidade a outras doenças.

\subsubsection{Coccidiose e a absorção de nutrientes}

A absorção de nutrientes é realizada de acordo com a demanda exigida pelo organismo, porém na presença de distúrbios intestinais esses valores encontram-se com seus níveis alterados. De acordo com Freeman (1970), enfermidades provocadas por agentes como os da coccidiose, podem causar anorexia e inflamação do trato intestinal do animal, resultando em uma inibição na absorção de nutrientes.

Valores plasmáticos normais para glicose podem estar ligados a uma boa saúde intestinal ou à glicogenólise hepática realizada pelo organismo da ave, onde a glicose é mantida em seus níveis basais por meio da quebra do glicogênio hepático mediante a liberação de glucagon pelo pâncreas. A capacidade que a ave possui de manter a normoglicemia em situações onde as reservas de glicogênio hepático estão esgotadas, se deve a gliconeogênese. Porém os disturbios intestinais, que afetam os niveis de glicose no organismo, ocasionam as aves a entrarem em estado de hipoglicemia, induzindo o pâncreas a produzir glucagon e utilizam as reservas de glicogênio hepático, tendo hipoglicemia apenas em casos graves devido à inibição da glicogenólise hepática (RUFF et al,1980; CHAPMAN,1983; FREITAS, 2008)

Casos de hipoproteinemia podem ser observados em determinadas fases da coccidiose, provavelmente devido à perda de proteínas através da parede do intestino. Turk (1968) sugere que durante infecções coccidianas a perda de proteínas plasmáticas diminui os efeitos da absorção dos nutrientes pela ave. Resultados semelhantes foram obtidos por Chapman (1983) ao infectar aves com $10^{5}$ oocistos esporulados de E. maxima, observou que as aves apresentaram uma leve hipoproteinemia na fase aguda da doença, não retornando aos valores normais até o $10^{\circ}$ dia-pós-infecção (dpi). 
Freitas et al. (2008) ao pesquisarem as alterações no metabolismo em frangos de corte infectados experimentalmente com E. acervulina, um dos principais agentes causador da coccidiose aviária, observaram que todas as classes de lipídios no soro e as lipoproteínas apresentaram-se reduzidas nos animais infectados. Resultados semelhantes foram encontrados por Allen (2002), que observaram diminuição na absorção de lipídios em aves infectadas com E. maxima.

Segundo Turk, (1968); Ruff, (1980); e Allen, (2002), infecções por coccídios acarretam a diminuição do $\mathrm{pH}$ do lúmen intestinal e, portanto, podem retardar a ação de hidrolases na quebra das moléculas, além de afetar a mucosa intestinal do animal, interferindo na absorção. Mudanças qualitativas ocorrem na superfície de absorção que é diminuída devido à descamação e atrofia das vilosidades. Estes autores reportaram que em estudos realizados com diferentes espécies de coccídeos indicaram que os efeitos nutricionais resultantes do parasitismo dependem da região do trato gasto intestinal afetada pelo parasitismo, da severidade da infecção, da fase do ciclo e do nutriente a ser estudado. Desta forma, a redução da absorção na fase aguda da doença esta correlacionada não só ao tipo de espécie causadora da doença, mas também esta correlacionada à carga parasitária existente no animal.

\subsection{DIAGNÓSTICO DE COCCIDIOSE}

O diagnóstico da coccidiose requer a identificação das espécies envolvidas e a quantificação da intensidade da infecção. $O$ diagnóstico específico tem sido tradicionalmente feito pela: a) morfologia e contagem de oocistos nas fezes das aves; b) localização e morfologia dos parasitas no intestino das aves; c) presença, característica, localização e intensidade das lesões macroscópicas no intestino; d) período mínimo de prépatência; e e) pelo tempo de esporulação dos oocistos (LONG et al., 1976; LONG, 1984).

O diagnóstico da doença pode ser feito ao nível de campo e laboratorial sendo baseado nos achados macroscópicos e confirmado microscopicamente, para a sua realização, deve-se selecionar ao acaso um grupo de animais do galpão, os quais serão sacrificados e submetidos à necropsia (KAWAZOE, 2000). 


\subsection{GÊNERO Eimeria spp.}

Segundo Kawazoe (2000), as espécies do gênero Eimeria, pertencem ao filo Apicomplexa, classe Sporozoea, sub-classe Coccidia, ordem Eucoccidiorida, sub-ordem Eimeriorina, família Eimeriidae. O filo Apicomplexa apresenta um conjunto de organelas características denominadas de complexo apical e são constituídas por anéis polares, conóide (organela de penetração), microtúbulos subpeliculares, roptrias (formação do vacúolo parasitóforo), micronemas (responsável pela adesão e reconhecimento da célula hospedeira) e grânulos densos (remodelação metabólica para o desenvolvimento do parasita) que reconhecem e se ligam a membrana dos enterócitos (KAWAZOE, 2000).

O filo Apicomplexa compreende um grande número de protozoários, sendo a maioria intracelular obrigatório. Esses organismos são caracterizados por apresentar o complexo apical que consiste de um conjunto de organelas que está envolvido com a adesão e penetração na célula hospedeira (CURRENT, 1990).

Segundo Castañon (2006), fazem parte do filo Apicomplexa alguns dos mais conhecidos e amplamente difundidos patógenos humanos, como os organismos dos gêneros Plasmodium, agente causador da malária, Toxoplasma, responsável pela toxoplasmose, Cryptosporidium e Cyclospora, que causam enterites severas. Outros gêneros pertencentes a este filo são de extrema importância na medicina veterinária devido aos graves prejuízos causados na produção animal, como é o caso de Eimeria, Isospora, Theileria e Babesia.

Os parasitas do gênero Eimeria apresentam um ciclo de vida monoxênico, iniciado quando um hospedeiro não imune é infectado pela ingestão de um oocisto esporulado (CURRENT et al., 1990; KAWAZOE, 1993; MCDOUGALD e REID, 1997), sendo que o gênero Eimeria caracteriza-se por apresentar um oocisto contendo quatro esporocistos com dois esporozoítos cada, num total de 8 esporozoítos por oocisto (FORTES, 1997).

\subsubsection{Eimeriose nas aves}

Eimeriose apresenta caráter endêmico nas granjas. Os agentes causadores da doença podem ser encontrados de forma prevalente em explorações comerciais ou não, levando ao desenvolvimento de uma doença entérica que resulta em menor capacidade absortiva do intestino, menor ganho de peso e, em alguns casos, aumento da mortalidade 
dos plantéis. São reconhecidas sete espécies do gênero Eimeria spp. que parasitam aves doméstica (Figura 1): E. acervulina, E. brunetti, E. maxima, . mitis, E. necatrix, E. praecox e E. tenella (SCHNITZLER, 1999; CASTAÑóN, 2006; LUCHESE, 2007).
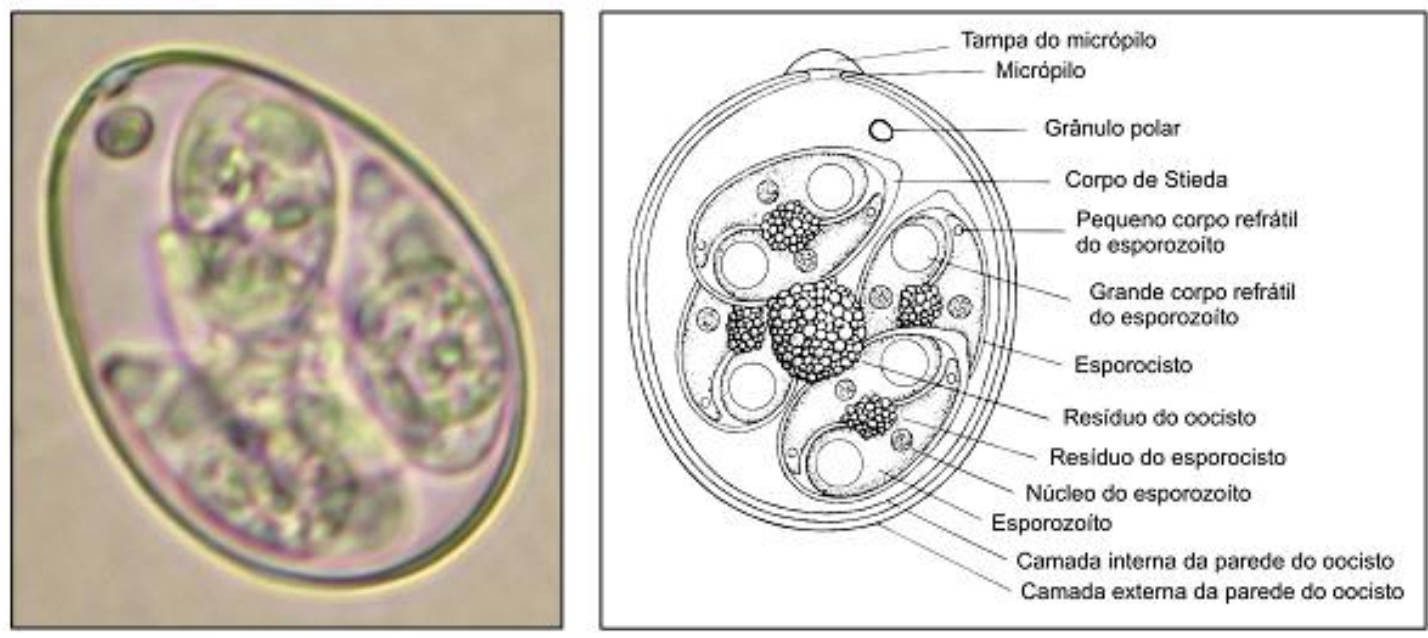

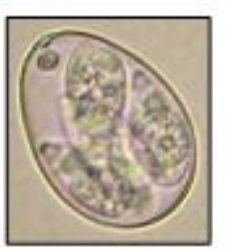

E. maxima

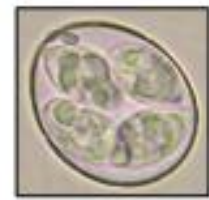

E. brunetti

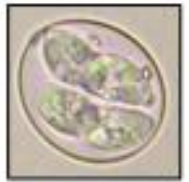

E. tenella

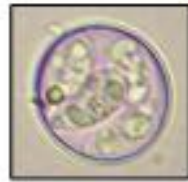

E praecox

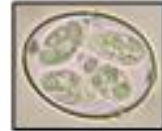

E. necatrix

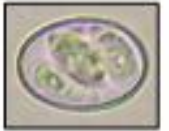

E. acervuina E. mitis

Figura 1: Morfologia das espécies de Eimeria causadoras de coccidiose em aves. (COCCIDIA, 2011).

Segundo Costa (2001), E. acervulina, E. maxima e E. tenella são comuns em frangos de corte e têm a sua ocorrência monitorada nessas criações por meio das lesões macroscópicas observados no intestino das aves. E. mitis e E. praecox também são comuns em frangos de corte mas não são monitoradas, em parte por não produzirem lesões macroscópicas que facilitem esse monitoramento e também por não serem consideradas importantes na cadeia produtiva. E. brunetti possivelmente não ocorra no Brasil e $E$. necatrix é o agente comum de coccidiose em matrizes.

Estudos realizados por Freitas et al. (2008), revelaram que nos animais infectados com E. acervulina apresentaram os sinais clínicos como: anorexia, diarréia e apatia. As alterações patológicas macroscópicas observadas constavam de: enterite, hiperemia seguido de congestão intestinal, excesso de exsudato mucoso no lúmen do intestino delgado, palidez e desidratação muscular, alto acúmulo de bile na vesícula biliar e deposição de gordura hepática. A atrofia de vilosidades e alta presença de células inflamatórias foram as alterações microscópicas observadas no epitélio intestinal. Desta 
forma, os resultados demonstraram que frangos de corte infectados experimentalmente com E. acervulina apresentam progressivas lesões intestinais de intensidade variável e que essas anormalidades são as principais causas de redução no desenvolvimento da ave.

\subsubsection{Ciclo Biológico}

As aves se infectam com espécies de Eimeria quando ingerem água ou ração contaminada com oocistos esporulados, contendo a forma infectante, o esporozoíto (KAWAZOE, 2000).

O ciclo parasitário inicia-se quando os oocistos esporulados são ingeridos e recebem uma série de estímulos, iniciando-se pela ação mecânica exercida pela moela das aves por trituração mecânica, liberando os esporocistos. Em seguida inicia-se uma fase altamente dependente de ativação enzimática, conhecida como excistação. No intestino do animal, devido à ação de sais biliares e enzimas proteolíticas como a tripsina, os esporozoítos são liberados ativamente do esporocisto. Os esporocistos contêm uma abertura denominada Corpo de Stieda. A tripsina-quinase auxilia na destruição dos corpos de Stieda dos esporocistos e liberação dos esporozoítos. A mobilidade do parasito é estimulada por sais biliares e pela temperatura interna do animal (CASTAÑón, 2006; ALLEN, 2002; DUBREMETZ, 1993; SOULSBY, 1987). Sob estes estímulos os esporozoítos completam a excistação e penetram ativamente nas células do epitélio intestinal (DUBREMETZ, 1993).

Seu ciclo de vida (Figura 2) desenvolve-se em um único hospedeiro (monoxeno), com multiplicação assexuada (merogonia ou esquizogonia) e sexuada (gametogonia) dentro das células do hospedeiro (estágios endógenos) e esporogonia no meio exterior (estágio exógeno) (KAWAZOE,1994). 


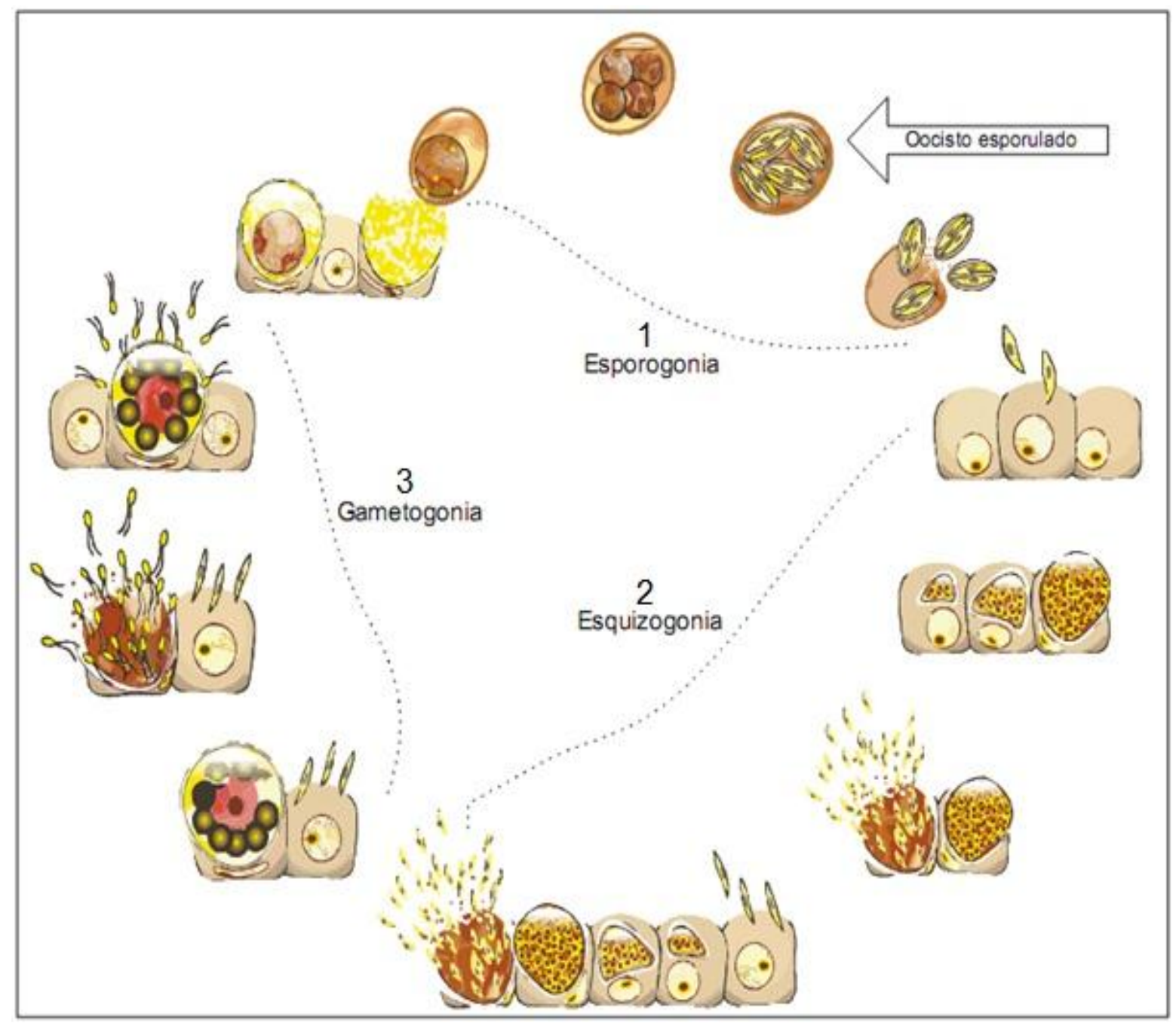

Figura 2 - Ciclo de vida da Eimeria spp. 1- Esporogonia: maturação do oocito, adquirindo caráter infectante via meiose; 2- Esquizogonia: Infecção e destruição das células intestinais do hospedeiro; 3 Gametogonia: processo de formação de gametas e formação um de um novo oocisto (BIOVET, 2005) 
Segundo Levine (1988), a esquizogonia inicia-se a partir de esporozoítos liberados de oocistos ingeridos, que penetram na parede intestinal e invadem células epiteliais, formando os merontes ou esquizontes. Durante a invasão da célula hospedeira antígenos representados por organelas do complexo apical (roptrias e micronema) executam um papel importante para o reconhecimento e penetração através da membrana da célula hospedeira e formam um vacúolo parasitóforo (Figura 3).
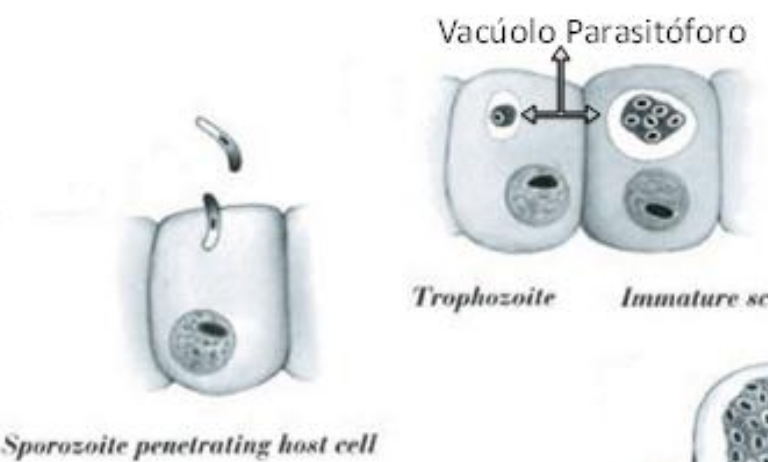

Trophozoite Immature schisont-Ixt generation

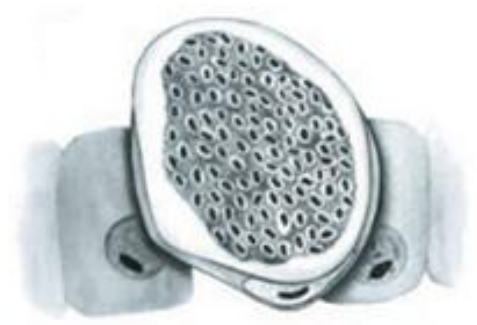

Immature schisont-Ist generution

Figura 3 - Mecanismo de infecção pelo trofozoíto e formação do vacúolo parasitóforo (Conway, 2007).

Levine (1998) afirma que trofozoítos, após divisão nuclear múltipla, dão origem a uma estrutura denominada Esquizonte, a qual matura um número variável de merozoítos que, quando maduros, rompem e escapam da célula hospedeira e invadem novas células onde passam por mais gerações de merogonia (Figura 4). Após certo número de gerações, de acordo com a espécie, os merozoítos, após invadirem novas células, dão origem a macrogamontes e microgamontes, que evoluem, respectivamente, em macrogametas (femininos) e microgametas (masculinos) (Figura 5). Cada macrogamonte dá origem a um macrogameta, enquanto cada microgamonte dá origem a vários microgametas, por divisão nuclear múltipla. Após a maturação, os microgametas flagelados rompem as células hospedeiras e vão fecundar os macrogametas, dando origem aos zigotos, e posteriormente aos oocistos imaturos que são eliminados juntamente com as fezes do hospedeiro. 


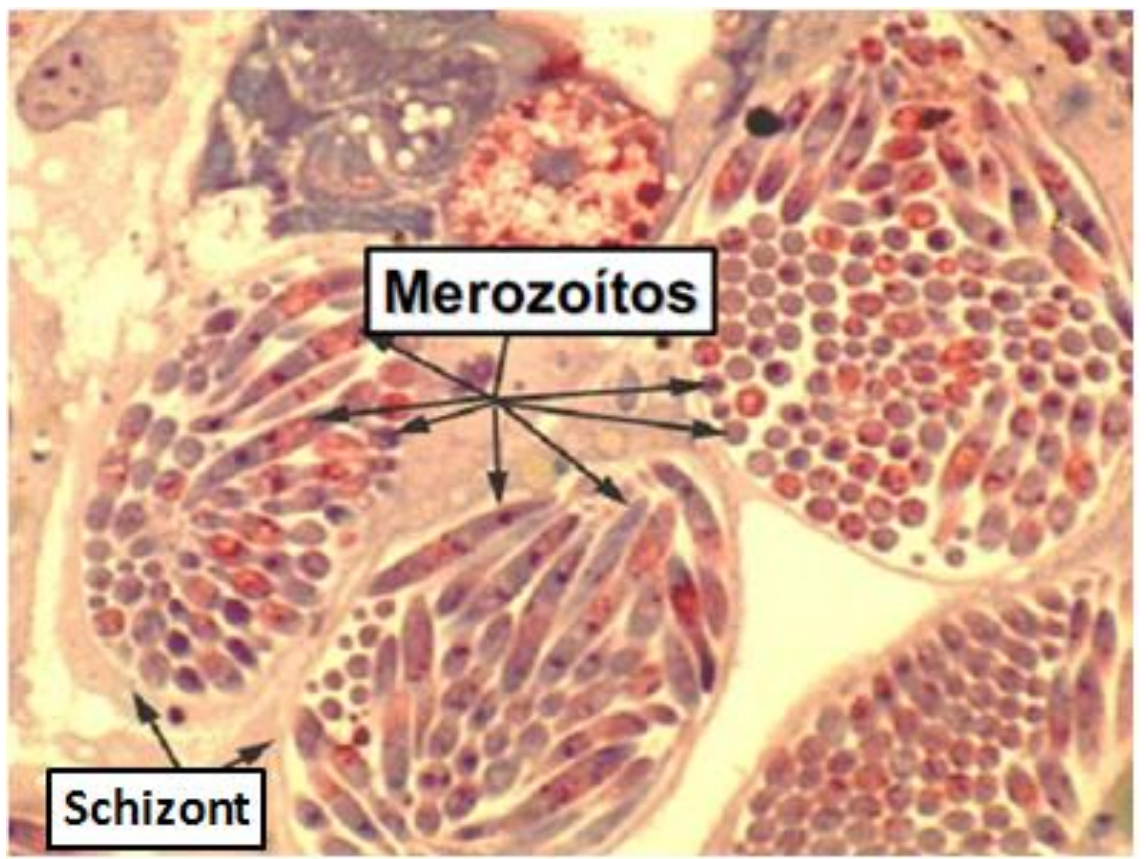

Figura 4: Desenvolvimento dos merozoítos no Esquizonte (AHID, 2009).

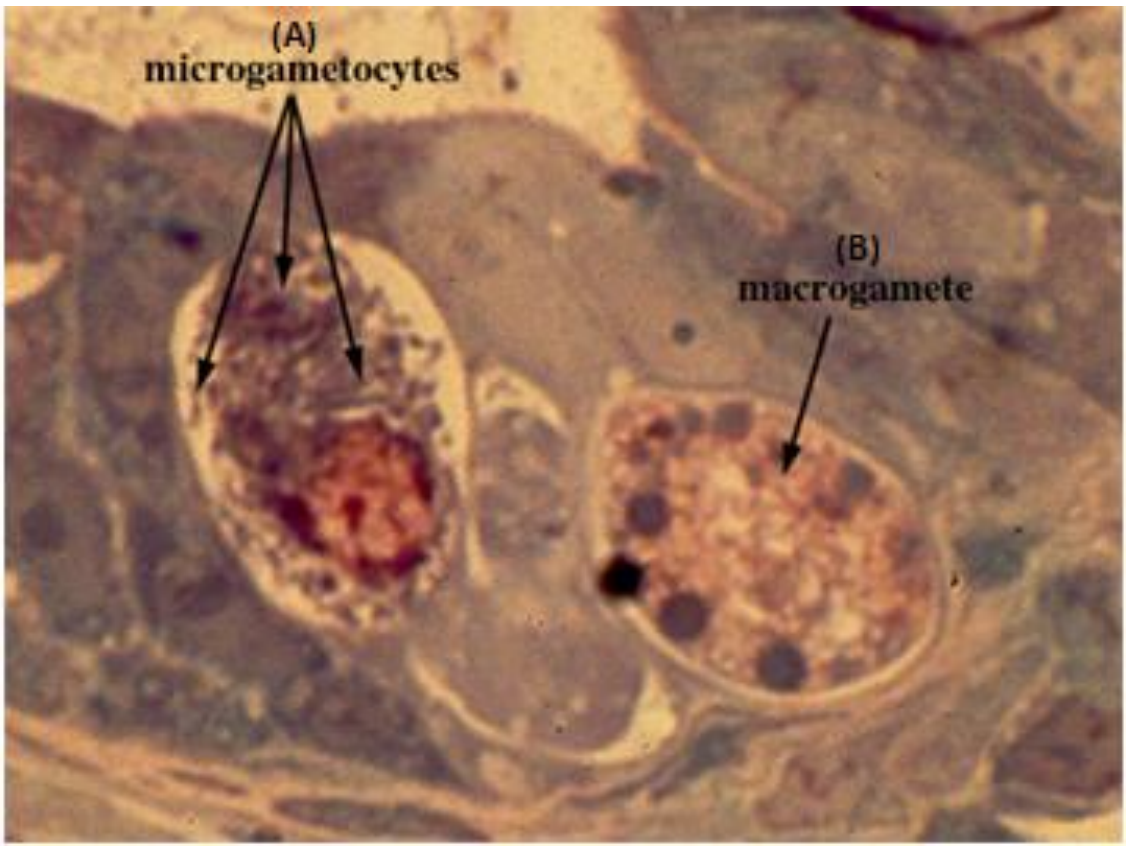

Figura 5: Presença de microgametócito e macrogametócito no tecido (AHID,2009). 
O oocisto é uma estrutura ovóide com parede dupla altamente resistente ao dessecamento e a diversas substâncias químicas, sendo por isso conhecido como a forma de resistência do ciclo de vida (SOUSLBY, 1987). Após sair da célula epitelial e ser eliminado nas fezes, sob condições ambientais adequadas, passa por um processo de esporulação ou esporogonia (FERNANDO, 1990). Tal processo requer a presença de oxigênio e, no caso de E. acervulina no mínimo 17 horas, variando com as condições de temperatura e umidade do ambiente (MACDOUGALD; REID, 1987). Ao final do processo cada oocisto esporulado contém quatro esporocistos cada qual com dois esporozoítos no seu interior.

Long at al (1976) relataram que o processo de esporulação é inibido quando encontram-se em temperaturas abaixo de $12^{\circ} \mathrm{C}$ ou acima de $39^{\circ} \mathrm{C}$. Kawazoe (2000), afirmou que as condições ideais de temperatura para que ocorra a esporulação está entre 28-30 ${ }^{\circ} \mathrm{C}$. Ao menos que sejam ingeridos pelas aves, oocistos expostos ao meio ambiente podem morrer após três semanas. A esporulação de oocistos pode ocorrer melhor em ambientes secos que úmidos. Oocistos esporulados podem ser imediatamente reingeridos para iniciar uma nova infecção.

\subsubsection{Eimeria acervulina}

Eimeria acervulina é um microrganismo intracelular obrigatório, parasita de células epiteliais do intestino delgado de aves domésticas (TEIXEIRA, 2007). Caracteristicamente E. acervulina acomete a parte proximal do intestino delgado na região do duodeno (Figura 6). É raro se observar este coccídio nas regiões mais profundas da mucosa, estando em sua maioria confinados ao epitélio da parte superficial das vilosidades. Nas infecções brandas as lesões causadas por E. acervulina estão associadas a faixas esbranquiçadas transversais ao eixo central do intestino delgado associadas à presença de oocistos e gametócitos nas vilosidades, onde as lesões causadas pelo parasita podem ser vistas na serosa do duodeno. Em infecções mais graves, as lesões são como placas coalescentes e a parede da mucosa se encontra espessada, podendo se observar um aspecto hemorrágico (FERNANDO, 1990). Em casos de infecções crônicas e duradouras acometendo aves de idade avançada o intestino se torna fino e friável perdendo o tônus muscular (LONG et al., 1976). 


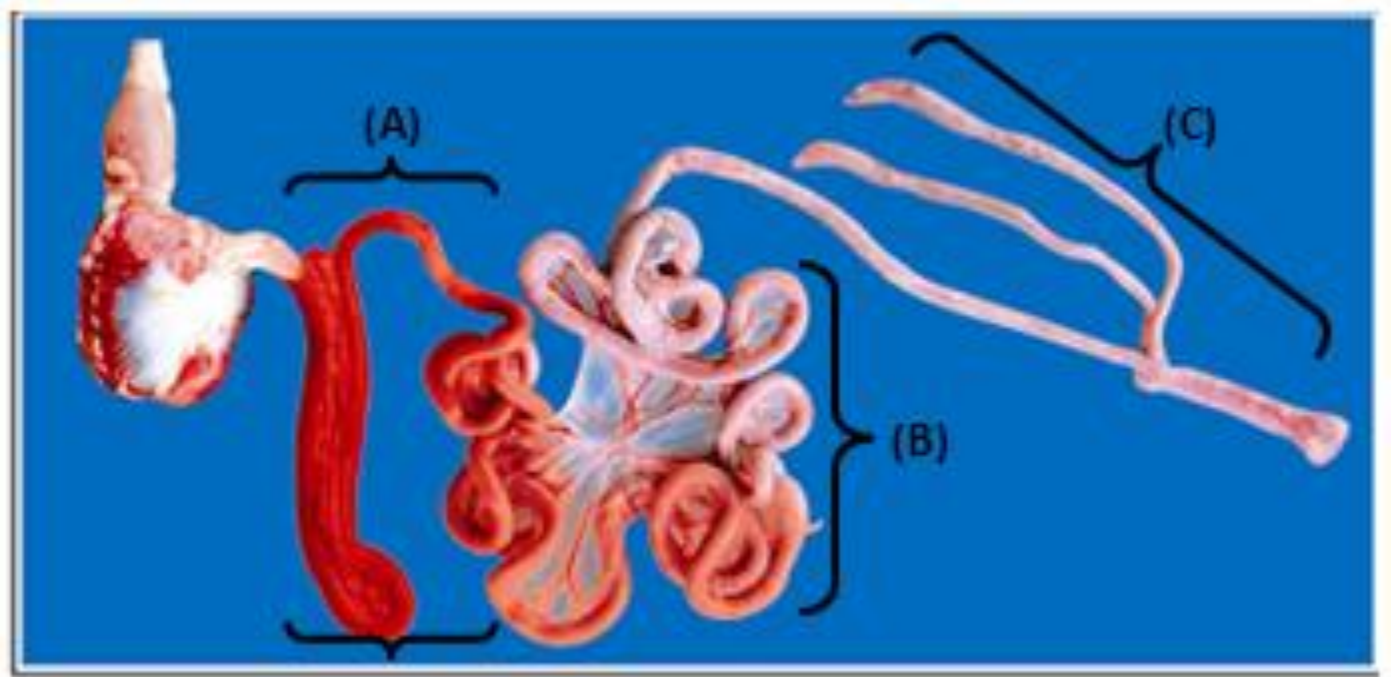

Figura 6: Trato gastrointestinal de uma ave infectada com Eimeria acervulina. (A) região proximal do intestido, denominado duodendo, local da infecção por $E$. acervulina; (B) Jejuno e; (C) Ceco (COCCIDIA, 2011)

A mortalidade nos animais infectados é baixa mesmo em infecções severas sendo, portanto considerado uma espécie mais mórbida do que letal, ou seja, o efeito da infecção no hospedeiro estará na dependência da magnitude da dose inicial infectante de oocistos que determinam o número de células invadidas por esporozoítos, de grau de disseminação da infecção no plantel, da imunidade dos animais, da presença de substâncias anticoccidianas na ração e do modo pela qual essas substâncias afetam o parasitismo (FAYER, 1980).

\subsection{CONTROLE DA COCCIDIOSE}

O controle da coccidiose em frangos de corte tem se baseado no uso preventivo de drogas anticoccidianas na ração (VERTOMMEN, 1994). Segundo Jeffers (1989), acreditava-se que a utilização desses produtos era uma solução definitiva, mas o surgimento de resistência das populações de Eimeria spp. aos anticoccidianos tem mostrado a necessidade de se desenvolver novas alternativas. Costa (2002) demonstrou que tradicionalmente as dificuldades encontradas no controle da doença têm sido resolvidas com o desenvolvimento de novas drogas e com o uso de estratégias como os programas duais de controle anticoccidiano e as rotações de uso de produtos.

Muito embora existam estratégias de controle da coccidiose em aves, a utilização de compostos químicos é o método mais comum no controle da coccidiose em granjas comerciais. Estes medicamentos são administrados desde o primeiro dia de vida das aves 
até sete dias antes do abate, respeitando o período de carência dos compostos no organismo animal (FILHO, 2001). Outra alternativa para o controle da coccidiose e para a redução do efeito de resistência é o uso de vacina com oocistos atenuados de espécies de Eimeria (DANFORTH, 1998; MUIR, 2000). Segundo Shirley (1989), o uso de vacinas atenuadas parece minimizar o risco do surgimento de coccidiose clínica no campo, eliminando a necessidade de quimioterapia subsequente, alem de conferir imunidade nas aves vacinadas.

Em um estudo realizado por Luchese (2007), com o objetivo de determinar a prevalência de espécies de Eimeria spp. em dois grupos de animais, sendo um de criação industrial constituído pela linhagem Hubbard tratado com Premix contendo medicamentos coccidiostáticos até sete dias antes do abate e outro grupo de frangos caipiras constituído pela linhagem Redro Plumé sem tratamento. O autor observou que os animais do sistema de criação caipira apresentaram maior incidência de oocistos nas fezes quando comparado com o grupo de criação industrial. Mesmo com o uso de drogas coccidiostáticas na ração do grupo de criação industrial, foi diagnosticada alta prevalência de coccídeos nas fezes dos Animais. Esta observação evidencia a baixa eficácia exercida pelos medicamentos coccidiostáticos presentes na ração devido a resistência aos agentes infecciosos, desta forma o uso de drogas coccidiostáticas na ração de frangos na forma de Premix, não elimina a possibilidade de existir infecções por agentes coccidianos.

\subsection{PROMOTORES DE CRESCIMENTO}

Um dos fatores que contribui para o aumento da produtividade na avicultura é, sem duvida, a utilização de aditivos na dieta. O termo aditivo inclui todas as substâncias, as quais, quando adicionadas às rações, são capazes de melhorar o desempenho animal ou as características físicas dos alimentos (SILVA, 2000; ARAUJO et al., 2007).

Os promotores de crescimento são os principais aditivos com efeito antimicrobianos de uso na alimentação animal, entre os quais incluem-se os antibióticos e os quimioterápicos que constituem de substâncias obtidas por síntese química, com ação semelhante à dos antibióticos (MENTEN; LODDI, 2003).

Dibner (2005), afirma que há muitos anos é sabido que os antibióticos quando usados na alimentação animal, com a finalidade de promover crescimento, acarretam em melhor desempenho zootécnico, fato este observado em trabalhos científicos. Além de serem empregados no tratamento de infecções do trato gastrintestinal (FLEMMING, 
2005), antibióticos quando utilizados em doses sub-terapêuticas melhora sensivelmente o crescimento e a eficiência de produção (BUTOLO, 1999; DIONIZIO, 2002; MENTEN; LODDI, 2003; FLEMMING, 2005; LORENÇON et al., 2007). Seu uso na ração impede que os microrganismos patogênicos invadam e se multipliquem no intestino do animal, permitindo assim que os nutrientes da dieta sejam melhor aproveitados promovendo o crescimento muscular (CORNELI, 2004; ARAUJO et al., 2007). Porém, o crescente questionamento quanto a possível relação existente entre o uso de antimicrobianos na dieta animal e o aumento da resistência bacteriana nos animais e no homem, provocou a adoção de novas medidas de controle do uso destes aditivos (FULLER, 1989; JIN, 1997; FERKET, 2003).

Apesar de não ser clara a associação entre o uso de antimicrobiano como promotores de crescimento na unidade de produção animal e o desenvolvimento de resistência nos patógenos e sua transferência à população humana, vários estudos epidemiológicos sugerem que o consumo de derivados animais seja uma possível via de transmissão de bactérias resistentes (SILVA, 2008). A principal preocupação é que o uso contínuo de antibióticos possa levar ao desenvolvimento e disseminação de populações bacterianas resistentes, e que essa resistência possa ser transferida aos microrganismos patogênicos, representando então, um risco, tanto para a saúde humana quanto animal (PIRVULESCU, 1999; LODDI, 2003).

Diversas organizações têm se manifestado contra o uso de antibiótico nas rações avícolas. Setores de imprensa, órgãos ligados a saúde, ONGs, entre outros, estão sensibilizando a opinião pública, principalmente em países desenvolvidos quanto aos possíveis problemas da adição de antibióticos nas rações, estimulando a criação de restrições por parte do mercado consumidor de carne e ovos (ALBINO et al., 2006).

Setores da saúde pública do Brasil têm se manifestado contra o uso de antibióticos e a sua proibição é iminente, seguindo a tendência mundial e obedecendo as normas internacionais para o banimento completo dos antibióticos (MILTENBURG, 2000). Muitos aditivos utilizados no passado tem seu uso proibido como: tetraciclinas, penicilinas, cloranfenicol, sulfonamidas sistêmicas, furazolidona, nitrofurazona e avorpacina. No Brasil ainda estão autorizados a utilização como promotores de crescimento de frangos de corte os seguintes produtos: ácido 3-nitro, ácido arsanílico, avilamicina, colistina, flavonicina, 
loncomicina, tilosina, virginiamicina, bacitracina, espiramicina e enramicina (ALBUQUERQUE, 2005).

Dados levantados em sete países da Comunidade Européia revelaram o impacto econômico representado pela proibição do uso de antibióticos como promotores de crescimento, sendo estimada uma perda da ordem de 176 milhões de dólares/ano para a produção de carne de frango e 30 milhões de dólares/ano para produção de ovos (ALBUQUERQUE, 2005).

Existe uma tendência em aumentar o uso de probióticos nas dietas dos animais em substituição aos antibióticos, sendo que a utilização do probiótico é mais racional, pois estes não deixam resíduos no meio ambiente, na carcaça do animal e não provoca resistência cruzada no homem quando comparado com o antibiótico, e algumas pesquisas indicam que estes aditivos possuem propriedades que estimula o crescimento de frangos de corte (SILVA et al, 2000a).

Segundo Salminen (1999), de forma geral microrganismos podem ser classificados em três grupos: (1) não-patogênicos; (2) patógenos oportunistas; e (3) patógenos. Independente do conceito utilizado, os probióticos trazem benefícios à saúde do hospedeiro, não deixam resíduos nos produtos de origem animal e não favorece o surgimento de resistência às drogas, o que os tornam candidatos preferenciais para substituir os compostos antimicrobianos empregados como aditivo alimentar (NEPOMUCENO, 2000; GIL DE LOS SANTOS, 2005).

Segundo Loddi (2003), na década de 70 destacou-se o uso de aditivos probióticos para animal, sendo empregado o microrganismo Lactobacillus acidophilus.

Trabalhos realizados no Brasil empregando probióticos na criação de frangos de corte mostraram que, no que se refere ao desempenho zootécnico, as respostas são praticamente equivalentes às apresentadas com o uso dos antibióticos (MENTEN; 2003; ZULKIFLI et al., 2000). Diversos estudos apresentaram bons resultados na melhora do ganho de peso e conversão alimentar (EDENS, 2003; FERREIRA et al., 2002; JIN et al., 1998). 


\subsection{PROBIÓTICO}

FAO (2001) defini probióticos como microrganismos vivos, os quais quando administrados na concentração adequada conferem benefícios a saúde do hospedeiro. Segundo Santos (2005), o conceito de probióticos tem mudado ao longo do tempo, sendo que para Fuller (1989) e Kaur et al (2002), probióticos são suplementos alimentares constituídos por microrganismos vivos que atuam no equilíbrio da microbiota intestinal do hospedeiro, trazendo benefício a sua saúde. Schrezenmer (2001) afirma que o termo "probiótico" designa produtos que contenham microrganismos viáveis, definidos e em quantidade adequada, produzindo efeitos benéficos para sua saúde. Desta forma, segundo Nepomuceno (2000), os probióticos trazem benefícios a saúde do hospedeiro, não permanecendo como resíduo nos produtos de origem animal, tornando-os preferenciais para substituir compostos antimicrobianos como aditivos alimentares.

De acordo com Salminen et al. (1998), os microrganismos probióticos são também utilizados para prevenir ou tratar diversas disfunções gastrointestinais, tais como a intolerância a lactose, constipação, hipersensibilidade alimentar e gastrenterite, como alergias e dermatite atópica. Os microrganismos usados como probióticos devem apresentar certas propriedades como: estabilidade quando expostos à ação de ácidos e sais biliares; aderência aos enterócitos e muco intestinal; exercer exclusão competitiva e colonizar o trato intestinal, produzir substâncias antimicrobianas e apresentar antagonismo as bactérias patogênicas, dentre outras.

Gibson (1995), afirma que um bom probiótico deve apresentar características como: sobreviver às condições adversas do trato gastrointestinal; não apresentar propriedades toxicas ou patogênicas ao hospedeiro; ser estável e permanecer viável durante a estocagem da preparação; apresentar capacidade antagônica às bactérias indesejáveis do trato gastrointestinal; e possuir propriedades comprovadas de benefícios ao hospedeiro.

Preparações probióticas apresentam diferentes composições no tocante às espécies de microrganismos e, mesmo aqueles pertencentes à mesma espécie podem ser constituído por diferentes cepas. A eficácia do produto probiótico é estritamente dependente da quantidade e características das cepas de microrganismos utilizadas na sua elaboração (LODDI, 2003). 
Os principais gêneros bacterianos utilizadas no preparo de probióticos são: Lactobacillus spp, Bifidobacterium spp, Enterococcus faecium e Bacillus spp. (FERREIRA et al., 2002; SIMON et al., 2001).

Pesquisas realizadas mostraram resultados promissores na adição de preparação probiótica na dieta de frangos de corte (SANTOS, 2005). Bactérias do gênero Lactobacillus, adicionadas a ração, aumentaram o ganho de peso e melhoraram a conversão alimentar dos animais suplementados (JIN et al., 1998a; JIN et al, 1998b; KALAVATHY et al., 2003). Demonstrou-se também o aumento do ganho de peso em animais suplementados com L. agilitis JCM 1048 e L. salivarus subsp. salicinius JCM 1230 (LAN et al., 2003) e L. acidophilus I 26 (JIN et al., 1998a), que também melhorou a conversão alimentar. Da mesma forma Moreno et al. (2002) apud SANTOS, (2005) comprovaram os efeitos positivos de probióticos constituídos por espécies de Lactobacilus sobre a digestibilidade, ganho de peso e níveis de colesterol em frangos de corte.

\subsubsection{Microbiota gastrointestinal das aves}

A microbiota do trato gastrintestinal das aves apresenta uma população heterogênea e complexa, bastante dinâmica, constituída por inúmeras espécies bacterianas (SAVAGE, 1977). A colonização intestinal, após a eclosão e alojamento das aves, tende a persistir ao longo do ciclo de vida da ave, passando a compor a microbiota normal (SILVA, 2008).

Loddi (2003) relata que animais recém nascidos adquirem sua microbiota intestinal de forma peculiar, segundo sua espécie. Nas aves, entre as silvestres ou criadas de forma livre e aves destinadas ao consumo, onde os ovos são coletados e eclodidos em incubadoras, existe grande diferença na forma em que ocorre a colonização intestinal. Pintinhos recém eclodidos em ambientes naturais, como campos ou matas, forma sua microbiota intestinal via bico ou a partir de excremento da mãe. Aves cujos pintinhos são eclodidos em incubadoras, não possuem meios para colonizar seu trato gastrointestinal, apresentando susceptibilidade a todos os tipos de contaminação por bactérias patogênicas.

Esses microrganismos, uma vez estabelecidos no intestino, formam um sistema complexo e dinâmico constituído de aproximadamente 400 espécies diferentes de bactérias. Uma vez estável estes microrganismos conferem ao animal resistência às infecções, particularmente observadas no trato gastrointestinal (LODDI, 2003). Gedek (1986) afirma que a presença dessa microbiota em equilíbrio é tão necessária quanto 
benéfica para o bem estar do hospedeiro, onde o desequilíbrio, em favor das bactérias indesejáveis, tais como Escherichia coli, Clostridium spp., Staphylococcus spp., Pseudomonas spp, resulta em infecções intestinais severas que, muitas vezes, podem ser fatais.

No trato gastrointestinal das aves, em situações normais predominam, no inglúvio, espécies de Lactobacillus gerando um $\mathrm{pH}$ ligeiramente ácido, sendo que no pró-ventrículo e moela o pH é extremamente ácido, praticamente inviabilizando a presença de microrganismos. No intestino das aves ocorrem espécies de bactérias Gram positivas como Lactobacillus spp. Enterococcus faecalis e Enterococcus faecium e no ceco predominam os microrganismos do gênero Clostridium e Gram negativos (GARLICH, 1999).

Para a permanência dos lactobacilos no intestino, torna-se necessário a ingestão diária de pequenas doses de produtos probióticos, uma vez que as espécies de lactobacilos são liberadas constantemente nas fezes, por meio da peristalse, dificultando assim a colonização no intestino (PEREIRA, 2007).

Segundo Corrêa (2003), um pool de microrganismos com capacidade probiótica constituído por L. acidophilus, L. casei, Streptococcus salivarium, E. feacium, B. subtilis, B. toyoi e $S$. cerevisiae avaliado quanto a sua eficácia no desempenho zootécnico e rendimento de carcaça de frangos de corte, demonstra que aves tratadas com o referido pool apresentaram melhor conversão alimentar, demonstrando assim o seu efeito positivo como promotor de crescimento.

\subsubsection{Mecanismo de ação dos probióticos}

Os microrganismos probióticos competem com os patógenos na ocupação dos sítios de aderência nas vilosidades intestinais, impedindo a livre fixação dos mesmos, protegendo as vilosidades e a superfície absortiva de toxinas irritantes produzidas pelos microrganismos patogênicos, permitindo a regeneração da mucosa lesada (PETRI, 2000).

Segundo Finger (2008), são quatro os mecanismos de ação exercidos por microrganismos probióticos, sendo que podemos conferir: competição por sítios de ligação; produção de substâncias antibacterianas e enzimas; competição por nutrientes; e estimulo do sistema imune. Os probióticos podem ser administrados de varias maneiras, 
podendo ser misturados na ração, adicionados na água ou pulverizados diretamente nas aves ou na cama.

Loddi (2003) relata a capacidade de microrganismos do trato gastrointestinal em resistir ao estabelecimento de células invasoras se deve a um processo denominado de Probiose.

Santos (2005), afirma que um aspecto de interesse crescente é o estudo do efeito dos probióticos na translocação de patógenos, e no sistema imune do hospedeiro. Assim, segundo este autor tem sido relatado que alguns produtos probióticos afetam a translocação bacteriana a partir do intestino.

\subsubsection{Exclusão Competitiva}

Segundo Nurmi (1973), a teoria da exclusão competitiva surgiu para designar a inabilidade de uma população de microrganismos em se estabelecer no trato gastrointestinal devido à presença de outra população. As bactérias com propriedades probióticas ocupam sítios de ligação (receptores ou pontos de ligação) na mucosa intestinal, formando uma barreira física às bactérias patogênicas (GHADBAN, 2002). É preciso 40 bactérias para recobrir a superfície de uma célula intestinal, o que contribui para a exclusão das bactérias patogênicas (LODDI, 2003).

De acordo com Kos et al. (2003), o fenômeno de adesão nas células epiteliais do intestino é um importante pré-requisito para a colonização de cepas probióticas, prevenindo sua eliminação imediata pela peristalse, favorecendo a competitividade neste ecossistema.

Loddi (2003) afirma que as fímbrias são os elementos de aderência bacteriana mais conhecidos e estudados. São compostas por lectinas, que reconhecem oligossacarídeos específicos dos sítios de ligação da parede intestinal. Algumas espécies de bactérias somente se aderem à superfície superior (glicocalix) dos enterócitos, enquanto que outras residem somente nas criptas onde são produzidas as novas células epiteliais que migram até as vilosidades. Algumas destas fimbrias podem ser bloqueadas pela manose. Assim, o uso de mananoligossacarídeos (MOS) pode bloquear a aderência das bactérias patogênicas neste tipo de fímbria. 
Desta forma, segundo Petri (2000), a aderência à mucosa intestinal apresenta-se como um mecanismo chave da colonização das bactérias patogênicas, e seus efeitos nocivos sobre a saúde do hospedeiro.

\subsubsection{Produção de substâncias antibacterianas}

Segundo Petri (2000), os microrganismos presentes no trato gastrointestinal podem produzir e liberar compostos como bacteriocinas, ácidos orgânicos e peróxido de hidrogênio, que tem ação bactericida sobre demais bactérias.

As bactérias do trato gastrointestinal (TGI), utilizando-se de ingredientes alimentares não absorvidos integralmente pelo hospedeiro (prebióticos), produzem alguns ácidos orgânicos, como propiônico, acético, butírico e láctico, além do peróxido de hidrogênio, cujos espectros de ação incluem também a inibição do crescimento de bactérias patogênicas (FURLAN et al, 2004).

Bactérias ácido lácticas produzem nisina, diplococcina, lactocidina, bulgaricina e reuterina. Estas substâncias apresentam atividade inibitória tanto para bactérias Gramnegativas quanto para Gram-positivas, como Salmonella spp., E. coli e Staphylococcus spp (LODDI, 2003). Podem produzir, também, substâncias com capacidade de neutralizar enterotoxinas, as quais são produzidas por bactérias patogênicas (GHADBAN, 2002).

\subsubsection{Competição por nutrientes}

Competição por nutrientes ocorre entre as bactérias presentes no trato gastrointestinal, para obtenção das fontes de carbono e outros elementos, disponíveis na luz intestinal. Desta forma, microrganismos probióticos, capazes de exercer este mecanismo de ação, metabolizam nutrientes que são essenciais para o desenvolvimento de microrganismos patogênicos, limitando assim a existência deste no TGI. (LODDI, 2003; FERREIRA, 2006). 


\subsubsection{Estímulo ao sistema imunológico}

O trato intestinal das aves é o órgão de maior responsabilidade no desenvolvimento da imunidade geral e específica (JIN et al., 1997).

Altos níveis zootécnicos na produção de frangos dependem diretamente do sistema imune. É por meio da imunidade que o animal se defende dos patógenos aos quais estão expostos diariamente, portanto é de extrema importância que este sistema esteja atuando de forma adequada e eficiente para impedir a introdução de doenças no organismo da ave e conseqüentemente interferir no desempenho zootécnico (MORGULIS, 2002).

Diferentes de todas as outras espécies animais, as aves não apresentam lifonodos. Seus órgãos linfonodos, espelhados ao longo do trato gastrointestinal, são as placas de Peyer, tolsilas cecais, incluindo a Bursa de Fabricius que é uma invaginação da parte final do trato digestório. Estes tecidos captam antígenos disponibilizados no trato gastrointestinal que estimulam as células B, colaboradoras das placas de Peyer, para o desenvolvimento de imunidade geral e inespecífica. Por meio do estimulo imunológico da mucosa, há produção de anticorpos tipo IgA que bloqueiam os receptores e reduzem o número de bactérias patogênicas na luz intestinal (JIN et al., 1997).

Relatos da literatura indicam que os vários tipos de probióticos existentes possuem algum efeito imunomodulador (COPPOLA; TURNES, 2004). Acredita-se que as alterações imunológicas induzidas pelos probióticos não estão limitadas a imunidade local da mucosa intestinal, há também relatos de efeitos sobre a resposta imune sistêmica, a qual mobiliza as células de defesa do corpo para o local da infecção (PERDIGON et al., 1995; ERICKSON; HUBBARD, 2000). Desta forma, as bactérias probióticas apresentam a capacidade de modulação de respostas imunes sistêmicas aumentando o número e a atividade de células fagocíticas do hospedeiro (FERREIRA; ASTOLFI-FERREIRA, 2006).

Gêneros de bactérias que estão diretamente relacionadas com o aumento da imunidade das aves incluem os Lactobacillus spp. e Bifdobacterium spp. (ERICKSON; HUBBARD, 2000; MENTEN; LODDI, 2003).

Embora haja diversos estudos voltados para a prevenção de doenças e o aumento da resposta imune quando da ingestão de probióticos, principalmente na medicina humana, os mecanismos específicos de ação destes microrganismos ainda não estão bem esclarecidos 
(ERICKSON; HUBBARD, 2000; FERREIRA et al., 2002; MENTEN; LODDI, 2003). Muito pouco se sabe sobre os mecanismos de defesa apresentados pelos probióticos nas aves (DALLOUL, 2003; FERKET, 2003).

\subsection{EFEITO ANTIPARASITÁRIO DOS PROBIÓTICOS}

Segundo Oliveira Sequeira (2008) o emprego de preparações probióticas tem sido amplamente investigado no tratamento ou na prevenção de infecções intestinais. Experimentos clínicos têm sido conduzidos com o intuito de se avaliar os efeitos de microrganismos probióticos na prevenção e no tratamento de desordens gastrointestinais causadas por espécies patogênicas ou por desequilíbrio da microbiota normal. Com isso, acumulam evidências de que o consumo de probióticos está relacionado à melhoria de parâmetros indicadores de saúde e bem-estar animal, os quais são mediados por um ou mais mecanismos de ação. $\mathrm{O}$ autor ressalta ainda que nas gastrenterites os principais mecanismos pelos quais os probióticos exercem sua ação benéfica incluem a exclusão competitiva (compeptição por nutrientes ou sítios de adesão), excreção/secreção de substâncias antimicrobianas (bacteriocinas) e estímulo do sistema imunológico do hospedeiro.

Considera-se o Cryptosporidium spp. como um importante agente causador de diarréia em seres humanos e animais. Em indivíduos imunocompetentes, a criptosporidiose é autolimitante, mas constitui uma grave e persistente infecção oportunista (OLIVEIRASEQUEIRA, 2008; YARLETT et al., 2007). Em estudo realizado por Coutinho (2008) demonstrou-se que a utilização de uma preparação probiótica constituída por diferentes cepas de Lactobacillus foi efetiva no tratamento de criptosporidiose, promovendo a eliminação da incidência de oocistos de Cryptosporidium parvum nas fezes de camundongos imunossuprimidos. Da mesma forma, Alak et al. (1999) avaliaram o efeito da administração de L. acidophilus e de L. reuteri sobre a infecção por Cryptosporidium spp. em camundongos imunossuprimidos e verificaram que ambas as espécies de Lactobacillus promoveram a diminuição da excreção de oocistos pelos camundongos.

Segundo Tierney et al. (2004), Eimeria spp. é um parasita intracelular que invade as células intestinais para se reproduzir. Este coccídeo se adere na superfície do endotélio parasitando as células do tecido, sendo que os microrganismos probióticos competem por esses sítios de adesão, ocupando os receptores das células epiteliais. De acordo com 
Pereira (2007), este mecanismo impede ou retarda a infiltração dos oocistos nas células do intestino e conseqüentemente provocam redução de sua proliferação assexuada que resultaria em redução na eliminação de oocistos nas fezes.

Pereira (2007) ao trabalhar com Rattus norvegicus infectados experimentalmente com Eimeria spp, relatou que o consumo de ração dos animais pertencentes ao grupo dos animais infectados foi inferior em relação ao grupo dos animais saudáveis. Esta observação se deve ao fato que a infecção provoca perda de apetite, menor ganho de peso e consequentemente deficiência na conversão alimentar. Os animais infectados com Eimeria spp., quando tratados com microrganismos com ação probiótica, interromperam o desenvolvimento do parasito, garantindo uma recuperação mais rápida em relação ao grupo controle.

A investigação da ação de um probiótico comercial à base de Lactobacillus spp. sobre coccidiose causada por Eimeria acervulina, em frangos de corte, revelou que os animais tratados apresentaram aumento significativo do número de linfócitos intraepiteliais e diminuição na excreção de oocistos na ordem de 75\% (DALLOUL et al., 2003). O aumento do número de células T, associado à posterior diminuição da excreção de oocistos, foi interpretado como sendo uma clara evidência de indução de resistência a esse coccídio (OLIVEIRA-SEQUEIRA 2008). 


\section{MATERIAL E MÉTODOS.}

O presente trabalho foi realizado no Laboratório de Probióticos da EEL-USP e no Aviário do Departamento de Zootecnia da Universidade Federal de Viçosa - UFV, ViçosaMG.

\subsection{PREPARAÇÃO PROBIÓTICA}

A preparação probiótica avaliada no presente trabalho foi constituída de um "pool" de 4 cepas de Lactobacillus, a saber: Lactobacillus casei ATCC 7469, L. plantarum ATCC 8014, L. fermentum ATCC 9338 e L. acidophillus ATCC 4536 oriundas da coleção de culturas do Laboratório de Probióticos da EEL, sendo mantidas a $4^{\circ} \mathrm{C}$ em meio ManRogosa-Sharpe (MRS) constituído de: peptona proteose (10.0 g/l); extrato de carne (10.0 $\mathrm{g} / \mathrm{l})$; extrato de levedura $(5.0 \mathrm{~g} / \mathrm{l})$; glicose (20.0 g/l); polisorbato (Tween) 80 (1.0 g/l); citrato de amônio (2.0 g/l); acetato de sódio (5.0 g/l); sulfato de magnésio (0.10 g/l); sulfato de manganês $(0.05 \mathrm{~g} / \mathrm{l})$; fosfato dipotássico $(2.0 \mathrm{~g} / \mathrm{l})$ e $\mathrm{pH} 6.5 \pm 0.2$.

Para a obtenção do "pool” de Lactobacillus., as respectivas culturas foram ativadas individualmente por meio de repicagens a $37^{\circ} \mathrm{C}$, durante $24 \mathrm{~h}$, por três vezes consecutivas em tubos de ensaio contendo caldo MRS, sendo o terceiro repique realizado em Erlenmeyer contendo $20 \mathrm{~mL}$ de caldo MRS. Em seguida, 2 alçadas foram transferidas para outro Erlenmeyer contendo $20 \mathrm{~mL}$ de caldo MRS e incubado nas mesmas condições, sendo o restante utilizado para composição do "pool" de lactobacilos. Este procedimento foi repetido por 7 dias consecutivos, sendo que a partir do $7^{\circ}$ dia uma nova cultura "mãe" foi utilizada. Desta forma, a cada dia, após a transferência das duas alçadas, os volumes de cada frasco foram devidamente juntados para compor o "pool" contendo $10^{8} \mathrm{UFC} / \mathrm{mL}$. Com o objetivo de reduzir o volume deste pool a ser administrado aos animais, a referida preparação probiótica foi centrifugada a $5000 \mathrm{rpm}$, por 15 minutos, sendo o sobrenadante separado com auxílio de uma pipeta e o pelete formado re-suspendido em soro fisiológico em volume corresponde a $1 / 4$ do inicial. Desta forma, foram administrados aos animais em tratamento o volume de $250 \mu \mathrm{L}$.

A contagem de células presentes em cada suspensão foi conferida esporadicamente por meio da técnica “pour-plate” em Agar MRS, a $37^{\circ} \mathrm{C}$ por $48 \mathrm{~h}$. 


\subsection{Cepas de Eimeria acervulina}

A cepa de Eimeria acervulina empregada no presente trabalho foi adquirida do Departamento de Parasitologia da Universidade Estadual de Campinas, UNICAMP - SP em tubo de ensaio contendo $7 \mathrm{ml}$ de água destilada, contendo 20 milhões de oocistos esporulados, prontos para serem utilizados no procedimento de infecção dos animais.

\subsection{DELINEAMENTO EXPERIMENTAL}

No presente trabalho, foram empregados 120 pintinhos de corte, com 1 dia de vida, machos, da espécie Gallus gallus domesticus cedidos pelo Departamento de Zootecnia da Universidade Federal de Viçosa - UFV - Viçosa - MG.

Neste experimento, com duração de 42 dias, as aves foram divididas em 6 grupos, contendo 20 animais cada, os quais receberam água e ração “ad libidum”, sendo que após quatorze dias de vida foram submetidos aos seguintes tratamentos:

- Grupo 1: os animais receberam apenas ração, livre de anticotidiostático, e água "ad libidum" (controle negativo);

- Grupo 2: além de ração e água "ad libidum", os animais receberam durante todo o experimento uma dose diária de $250 \mu \mathrm{L}\left(10^{8} \mathrm{UFC}\right)$ da preparação probiótica

- Grupo 3: além de ração e água "ad libidum", os animais receberam uma única carga infectante contando $2 \times 10^{5}$ oocistos esporulados de E. acervulina (controle positivo);

- Grupo 4: além de ração e água "ad libidum", os animais receberam diariamente uma dose de $250 \mu \mathrm{L}\left(10^{8} \mathrm{UFC}\right)$ da preparação probiótica durante todo o período do experimento e após 5 dias do início do tratamento, foram infectados com $2 \times 10^{5}$ oocistos esporulados de E. acervulina;

- Grupo 5: além de ração e água "ad libidum", no primeiro dia do experimento os animais foram infectados com $2 \times 10^{5}$ oocistos esporulados de E. acervulina e paralelamente receberam uma dose diária de $250 \mu \mathrm{L}\left(10^{8} \mathrm{UFC}\right)$ da preparação probiótica, até o final do experimento.

- Grupo 6: além de ração e água "ad libidum", no primeiro dia do experimento os animais foram infectados com $2 \times 10^{5}$ oocistos esporulados de E. acervulina e após o 
surgimento dos sinais clínicos da infecção, os animais passaram a receber diariamente uma dose de $250 \mu \mathrm{L}\left(10^{8} \mathrm{UFC}\right)$ da preparação probiótica.

Os animais foram mantidos em gaiolas (Figura 7) e foram separados por grupo, onde os grupos 1 e 2 (controles) ficaram em salas separados dos demais grupos (infectados e tratamentos), no intuito de se evitar contaminação por E. acervulina.

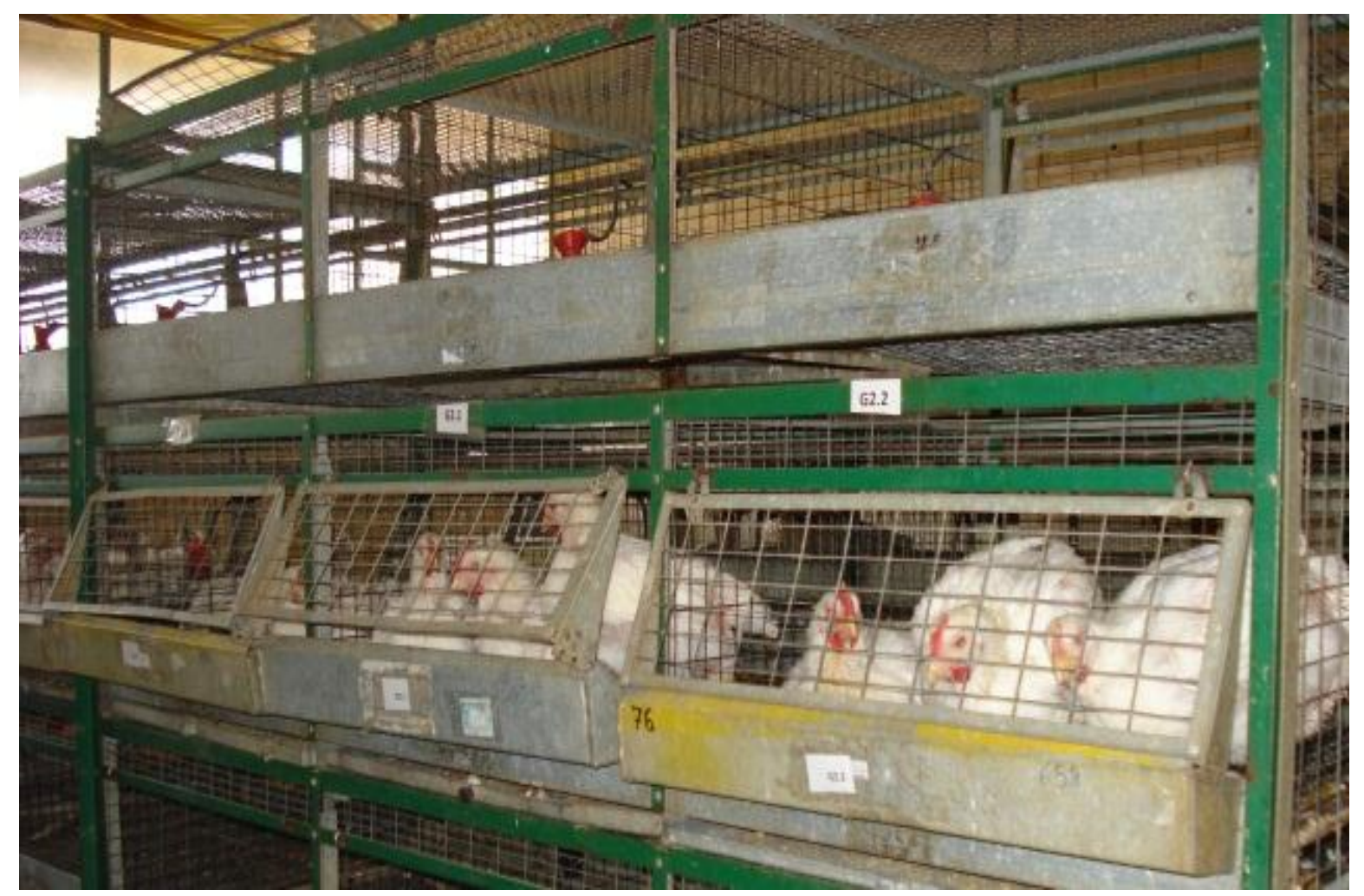

Figuras 7 - Gaiolas contendo os diferentes grupos de aves.

\subsection{COLETA DE MATERIAL PARA ANÁLISE.}

Para coleta de amostras de sangue, fezes e intestino, foram abatidas duas aves por grupo a partir do $14^{\circ}$ dia de vida, correspondendo a $0,4,7,14,21$ e 28 dias de experimento.

\subsubsection{Contagem de oocistos de Eimeria acervulina nas fezes}

Amostras de fezes dos respectivos grupos foram coletadas diariamente para exames parasitológicos por meio de contagem de oocisto por gramas de fezes (OoPG), sendo a amostra coletada com auxilio de espátula, armazenada em recipientes plásticos e, 
posteriormente, analisada para determinar os períodos de pré-patência (espaço de tempo entre o momento em que se da a infecção do hospedeiro e a detecção do agente nos tecidos, secreções ou excretas) e patência (intervalo de tempo compreendido entre o início da eliminação de oocistos pelas aves e o término da infecção) de E. acervulina.

Para contagem de oocistos nas fezes pesou-se 2,0 $\mathrm{g}$ de fezes (previamente homogeneizada) que foram diluídas em $28 \mathrm{ml}$ de água supersaturada com $\mathrm{NaCl}$, sendo em seguida homogeneizadas e coadas, com auxilio de tamis. Em seguida adicionou-se $30 \mathrm{ml}$ de solução supersaturada de $\mathrm{NaCl}$, sendo homogeneizada e retirada uma alíquota para preencher a câmara Mc máster para contagem de parasitas em microscópio em aumento de 100x.

\subsubsection{Exames Histopatológicos}

Exames histopatológicos foram realizados no Laboratório de Histopatologia do Departamento de Medicina Veterinária, UFV- Viçosa - MG. Amostras de fragmentos do duodeno dos animais foram coletados, por meio de necropsia, onde os fragmentos foram submersos em solução formol $10 \%$ para preservação do tecido, em seguida fixados em parafina e submetidos a corte histológico, por meio de microtomia e submetidas a coloração com hematoxilina eosina (HE).

\subsubsection{Testes Bioquímicos}

A coleta de sangue $(5 \mathrm{~mL})$ dos animais dos grupos em estudo foi realizada por meio de punção intra-cardíaca, utilizando seringas e agulhas descartáveis (Figura 8). Estas foram imediatamente transferidas para tubos de ensaio e submetidas a exames bioquímicos no Laboratório Biofármacos I da UFV - Viçosa -MG. 


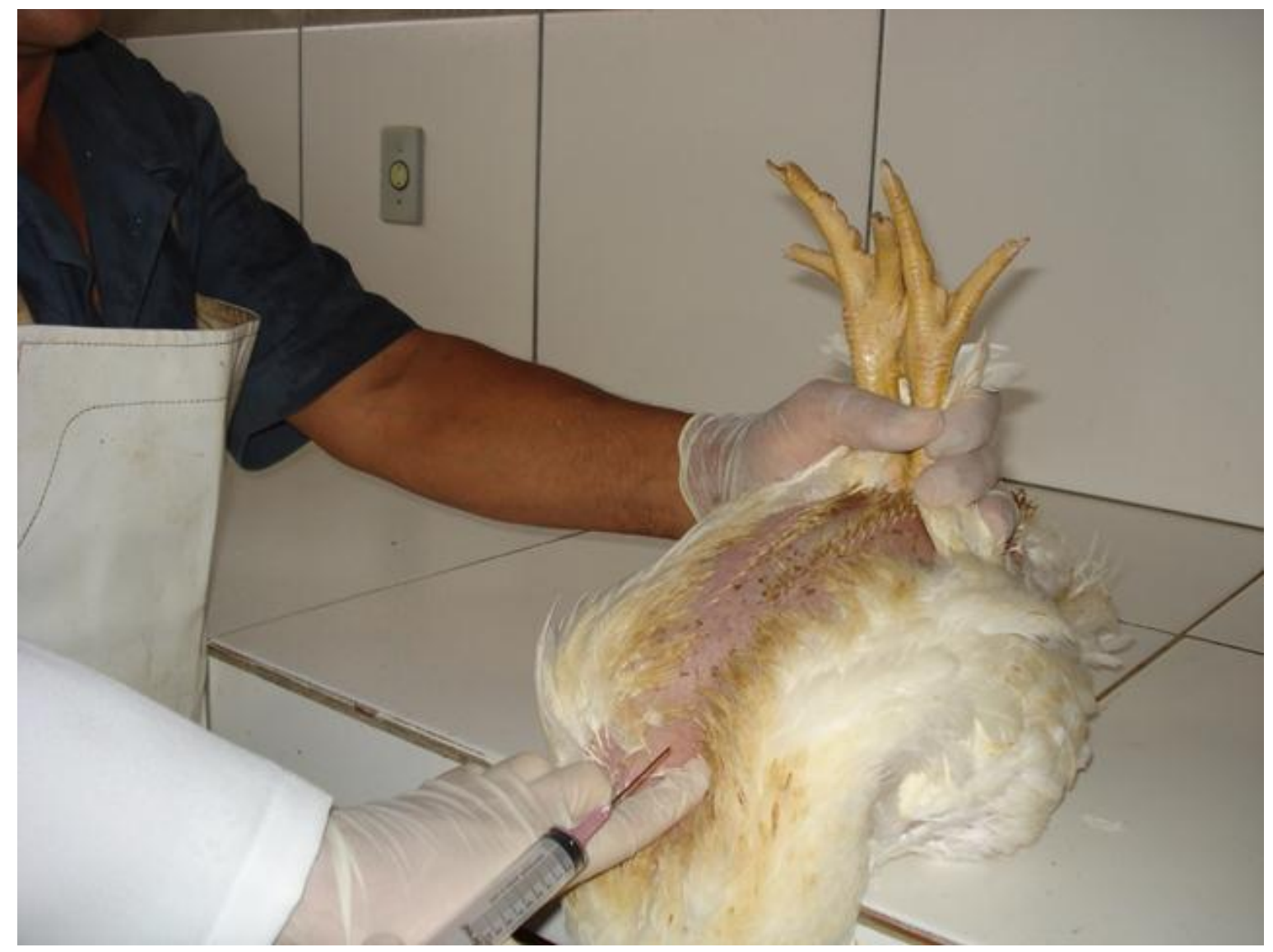

Figura 8 - Coleta de sangue, via intra-cardiaca.

As amostras de sangue foram coletadas em tubos de ensaio sem anticoagulante e centrifugadas a $2500 \mathrm{rpm}$ por 15 minutos para a obtenção do soro e submetidas a testes bioquímicos por meio de kits (glicose, proteínas totais e albumina; triglicerídeos, colesterol total, HDL). As amostras de sangue destinadas para exame de glicose foram armazenadas em tubos de ensaio contendo anticoagulante EDTA fluoretado.

\subsubsection{Desempenho Zootécnico}

O desempenho zootécnico dos animais foi avaliado por meio da taxa de conversão alimentar que consiste na relação entre o consumo de ração e o ganho de peso $(\mathrm{Kg} / \mathrm{Kg})$, conversão alimentar (consumo de ração/ganho de peso) e eficiência alimentar (ganho de peso/consumo de ração).

O consumo de ração foi verificado diariamente por meio da diferença entre a quantidade de ração disponibilizada aos animais e da sobra nos comedouros no dia seguinte. $\mathrm{O}$ ganho de peso foi observado por meio da pesagem diária dos animais. $\mathrm{O}$ 
rendimento de carcaça foi determinado por meio da relação entre o peso morto com vísceras comestíveis (coração, fígado, moela) e o peso vivo (PM/PV). Estas medições foram realizadas com auxílio de balança digital com capacidade de $5 \mathrm{~kg}$ com resolução de 0,5g (Figura 9).

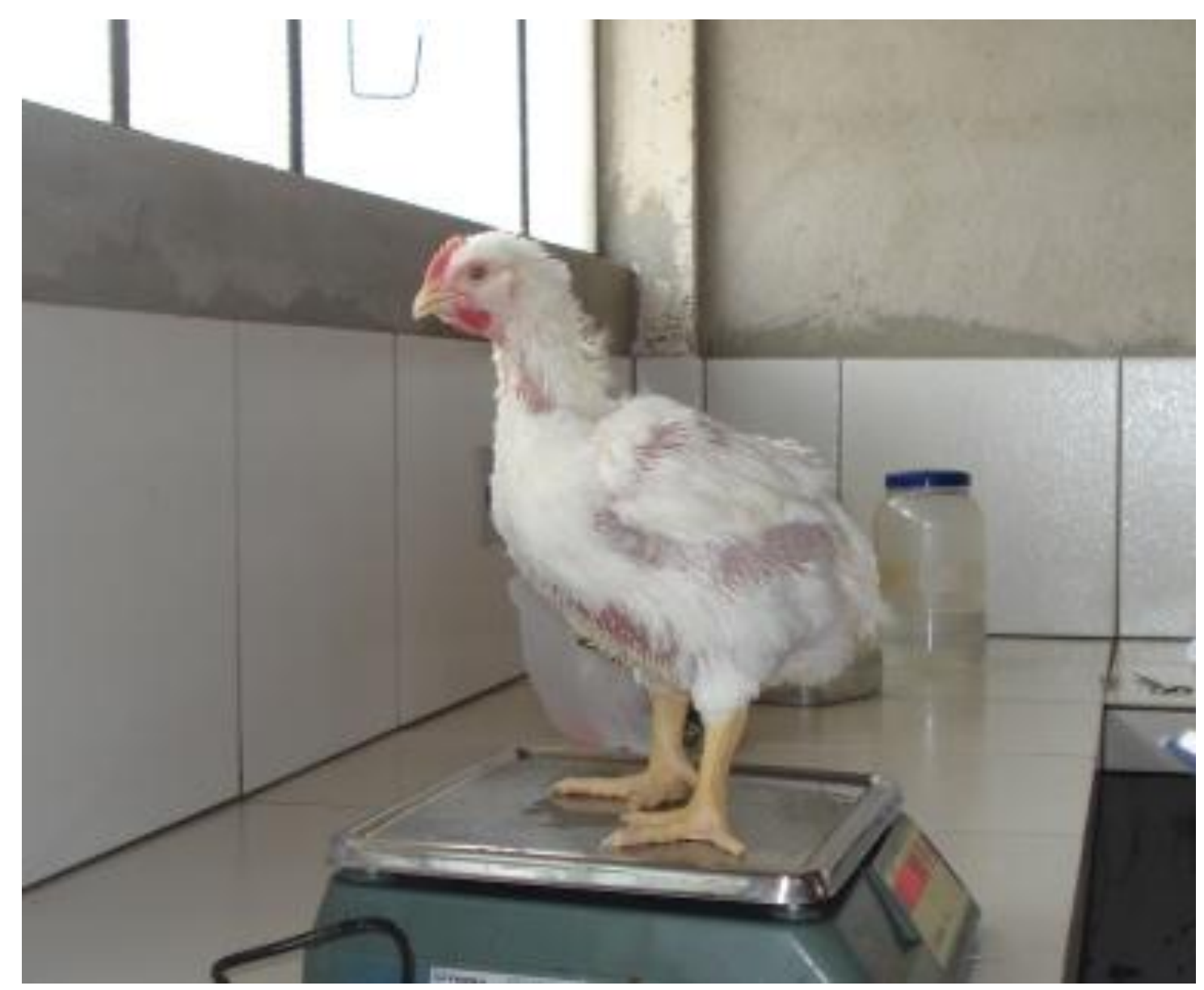

Figura 9 - Pesagem das aves para avaliação do desempenho zootécnico.

\subsubsection{Análise estatística}

Os resultados dos testes bioquímicos foram submetidos a análises estatísticas, por meio do programa Statistica 9.0, utilizando do método Test-T.

Para comparação dos respepcptivos resultados, considerou-se como referência os resultados relativos ao Grupo 1 (controle negativo). 


\section{RESULTADOS E DISCUSSÃO}

\subsection{ELIMINAÇÃO DE OOCISTOS NAS FEZES}

Para avaliar o efeito da administração de probiótico sobre a eliminação de oocistos foram definidos 4 grupos experimentais de frangos de corte infectadas com Eimeria acervulina, sendo Grupo 3, os animais foram infectados com o parasito (controle positivo) e não receberam tratamento; Grupo 4, os animais foram tratados com a preparação probiótica em estudo; Grupo 5, as aves foram infectadas com E. acervulina e imediatamente tratadas com a preparação probiótica; Grupo 6, as aves foram infectadas com E. acervulina e, após os primeiros sinais clínicos da doença, foram tratadas com a preparação probiótica em avaliação. Vale destacar que os animais pertencentes aos Grupos 1 e 2 (controle negativo) receberam água e ração "ad libidum", sendo que os animais do Grupo 1 não foram infectados e nem foram tratados e as aves do Grupo 2 foram tratadas com a preparação probiótica em estudo.

Os resultados referente à contagem de OoPG nas fezes das aves experimentalmente infectadas com $2 \times 10^{5}$ oocisto de E. acervulina encontram-se representados na Figura 10. De acordo com estes resultados observa-se que os animas pertencentes ao grupo 3 eliminaram maior quantidade de oocistos nas fezes, sendo justificado pela ausência de tratamento para o controle da infecção no referido grupo, possibilitando, desta forma, um desenvolvimento do parasito, livre de qualquer medida de controle, nas células intestinais das aves.

Resultado similar foi relatado por Teixeira (2007), no experimento realizado em frangos de corte também infectados com E. acervilina, onde os animais pertencentes ao grupo controle positivo apresentaram uma maior eliminação de oocistos comparado aos demais grupos tratados. Este autor observou também que os animais tratados com anticoccidiano, à base de salinomicina $(20.000 \mathrm{mg} / \mathrm{Kg})$, apresentaram menor eliminação de oocistos, pelo fato deste composto, ao ser administrado nos animais infectados, comprometer o equilíbrio osmótico do parasito e limitar sua invasão e reprodução nas células intestinais.

No presente estudo observa-se também, ainda na Figura 10, que as aves previamente tratadas com probiótico (grupo 4) apresentaram menor eliminação de oocistos 
nas fezes ao término do período patente (6 dias), evidenciando efeito benéfico do uso da preparação probiótica na alimentação animal. Resultados semelhantes foram obtidos por Matos (2010), que relatou que uma forma de ação dos microrganismos probióticos em promover o equilíbrio da microbiota intestinal se deve a adesão das células no epitélio intestinal, colonizando o TGI e dificultando a adesão de microrganismos patógenos, ação essa denominada de exclusão competitiva. Acredita-se que o efeito desta exclusão exercida pela preparação probiótica na prevenção da instalação da infecção nas células intestinais por E. acervulina, foi verificado nos grupo 4, 5 e 6, tendo em vista que as aves destes grupos apresentaram sinais clínicos da doença mais brandos, sendo evidente a redução do potencial biótico do parasito, devido à redução na eliminação de oocistos nas fezes.

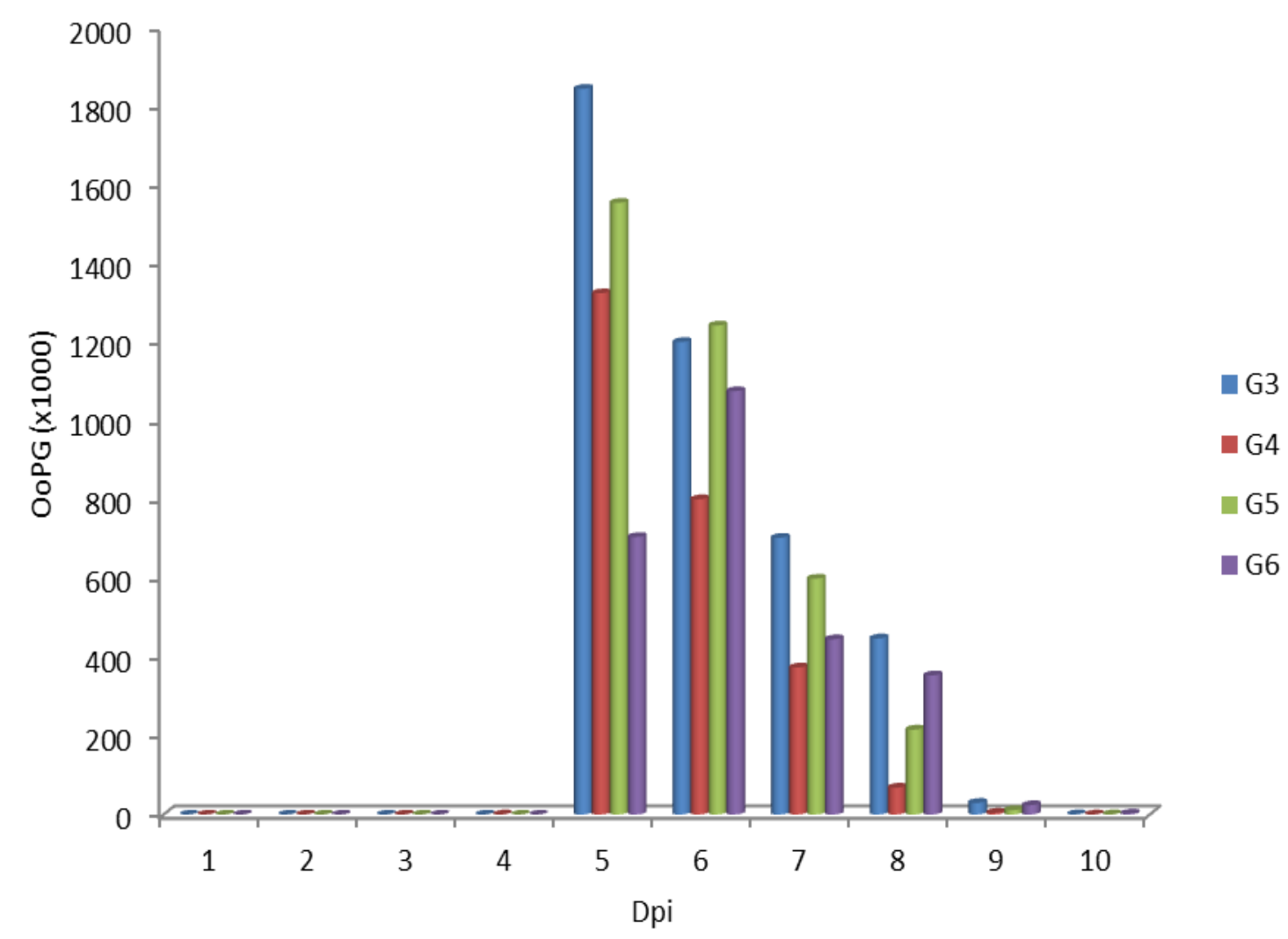

Figura 10 - Contagem de oocistos por grama de fezes em frangos de corte infectados com Eimeria acervulina e submetidos ao tratamento com preparação probiótica. 
Em infecções causadas por Eimeria spp. é comum o aparecimento de distúrbios gastrointestinais devido ação do parasito na parede intestinal do animal. Verificou-se no presente trabalho que as fezes dos animais pertencentes ao grupo 3 apresentaram consistência aquosa e fétida, resultando em sinais clínicos mais intensos de debilidade física e ausência de apetite. Dados similares foram relatados por Freitas et al. (2008), os quais utilizaram uma carga parasitaria de $10^{6}$ oocistos esporulados de E. acervulina para infectar frangos de corte, sendo que os animais apresentaram sinais de anorexia, seguida de um quadro de apatia e diarreia fétida com pequenas estrias esbranquiçadas, oriundas de lesões da parede intestinal resultante da alta carga parasitaria.

Em estudo realizado por Coelho (2010), no combate a helmintose canina, provocada por agentes da família Ancylostomidae, a aplicação de uma preparação probiótica composta por 4 cepas do Lactobacillus resultou em uma redução de até 88,83\% no número de ovos do parasito nas fezes dos animais após 28 dias de tratamento. Contudo, após o termino do tratamento houve um aumento no número de parasitos nas excretas, enfatizando, desta forma, a importância da administração continua da preparação probiótica na dieta dos animais. Em estudo similar, Teixeira (2011) avaliou a mesma preparação em ovinos infectados por Haemonchus contortus e observou uma redução de até $66,3 \%$ da carga parasitária, após 30 dias de tratamento. No presente trabalho, esta mesma preparação probiótica, promoveu uma redução de 84,14\% na eliminação de Oopg após o $9^{\circ}$ d.p.i. nos animais do grupo 4. Contudo, no tocante à eliminação de oocistos, a preparação probiótica em estudo reduziu a quantidade destes em 39,12\%, ao se comparar o grupo 4 com o grupo 3 (controle positivo). Neste caso, acredita-se que a baixa eficácia observada se deve ao fato que as cepas utilizadas no presente estudo, tenham origem na microbiota de animais mamíferos e não de aves.

Apesar dos animais dos grupos 5 e 6, que foram infectados com objetivo de se avaliar o efeito terapêutico da preparação probiótica, apresentarem uma menor eliminação de oocistos quando comparado ao grupo 3, nota-se que a quantidade de OoPG foi superior ao grupo 4, que foi criado para se avaliar o efeito preventivo exercido pela preparação probiótica em estudo sobre a eimeriose. Esta observação sugere que a referida preparação probiótica apresenta um caráter preventivo em relação a infecção por E. acervulina. Resultados semelhantes foram reportados por Pereira (2007), que avaliou a ação antiparasitária de 4 cepas de Lactobacillus sp sobre Eimeria spp. em Rattus norvengicus, e por Rossi (2007) que estudou o efeito na prevenção de salmoneloses em frangos de corte. 
A análise de fezes dos animais pertencentes aos grupos 1 e 2 foram negativas para infecção, ou seja, não apresentaram estruturas parasitarias sugestivas do parasito que indique a infecção pelo patógeno, sendo confirmado pelo exame histopatológico. Este resultado se deve às medidas profiláticas que foram adotadas para se evitar a infecção destes grupos e proporcionar bem estar aos animais. Para tanto, os animais dos Grupos $1 \mathrm{e}$ 2 foram devidamente separados dos demais grupos, tratados sempre com prioridade, para evitar infecção, porém que os procedimentos de higiene e manejo foram os mesmos para todos os grupos.

Animais de vida livre ou criados em confinamentos, seja para engorda ou outros fins, mesmo quando submetidos a alguma ação preventiva a enfermidades, estão sujeitos a infecções causadas por um ou mais espécies de patógenos. Quando ocorre uma infecção por um ou mais agentes parasitários, dá-se início ao ciclo de vida do parasito, o qual divide-se em dois períodos, chamados de período pré-patente e período patente. Caracteriza-se como período pré-patente o espaço de tempo onde ocorre entre o início da infecção até a eliminação dos primeiros ovos ou oocistos nas fezes do animal. O período patente é determinado pelo espaço de tempo compreendido entre o inicio da liberação dos oocistos nas fezes até a eliminação total dos oocisto, resultando no fim da infecção.

No presente trabalho o período pré-patente da E. acervulina foi de 96 horas, ou seja, finalizou no $4^{\circ}$ dia-pós-infecção (d.p.i.), sendo o mesmo observado por Teixeira (2007), Freitas (2008) e Carvalho (2009), em estudos envolvendo infecção de frangos de corte por E. acervulina. O período de patência observado foi de 6 dias cessando no $10^{\circ}$ d.p.i., sem reincidência. Teixeira (2007) observou que os animais, ainda que em baixa quantidade, continuaram a excretar oocistos nas fezes até o $20^{\circ}$ dpi. Fato semelhante foi relatado por Freitas (2008), cujo fim do período patente se deu no $18^{\circ}$ dpi. Nota-se no presente trabalho que o período patente foi menor em relação aos demais estudos, o que se deve, provavelmente, a baixa carga parasitaria administrada aos animais, resultando em menor eliminação de oocitos e, dessa forma, não exercendo maiores danos à saúde dos animais.

E. acervulina parasita as células epiteliais (enterócitos) do intestino delgado de aves domesticas, como galinhas destinadas a produção de aves ou frangos destinados ao corte, sendo um microrganismo intracelular obrigatório. Em seu ciclo biológico, monoxeno, $E$. acervulina, uma vez ingerida em sua forma esporulada da início a infecção, sendo que após 
o rompimento da membrana do parasita e dos corpos Stieda (estrutura que envolve os esporozoítos), ocorre a liberação dos esporozoítos, os quais dão início no processo de invasão celular, nas células epiteliais do duodeno, gerando a primeira geração de merozoítos. No presente estudo, apesar das aves apresentarem um período patente curto quando comparado aos demais trabalhos descritos na literatura, foi evidente o parasitismo nas células intestinais por meio da observação histopatológica (Figura 11) das estruturas parasitarias, por meio das quais verificou-se presença de vacúolos parasitóforos e oocistos nas células intestinais

Freitas et al.(2008), ao estudarem aves infectadas com E. acervulina, afirmam que as análises histopatológicas dos segmentos intestinais, principalmente do duodeno, caracterizaram-se por intensos infiltrados inflamatórios no epitélio intestinal, associado com descamação e atrofia de vilosidade. Quanto às estruturas parasitárias, como observado no presente estudo, no $4^{\circ}$ dpi uma vez que é possível observar grande quantidade de merontes na mucosa duodenal, menor quantidade no jejuno, localizando-se principalmente nas criptas do epitélio. Observa-se também grande quantidade de macrogamontes e microgamontes, assim como zigotos e oocistos recém formados. 

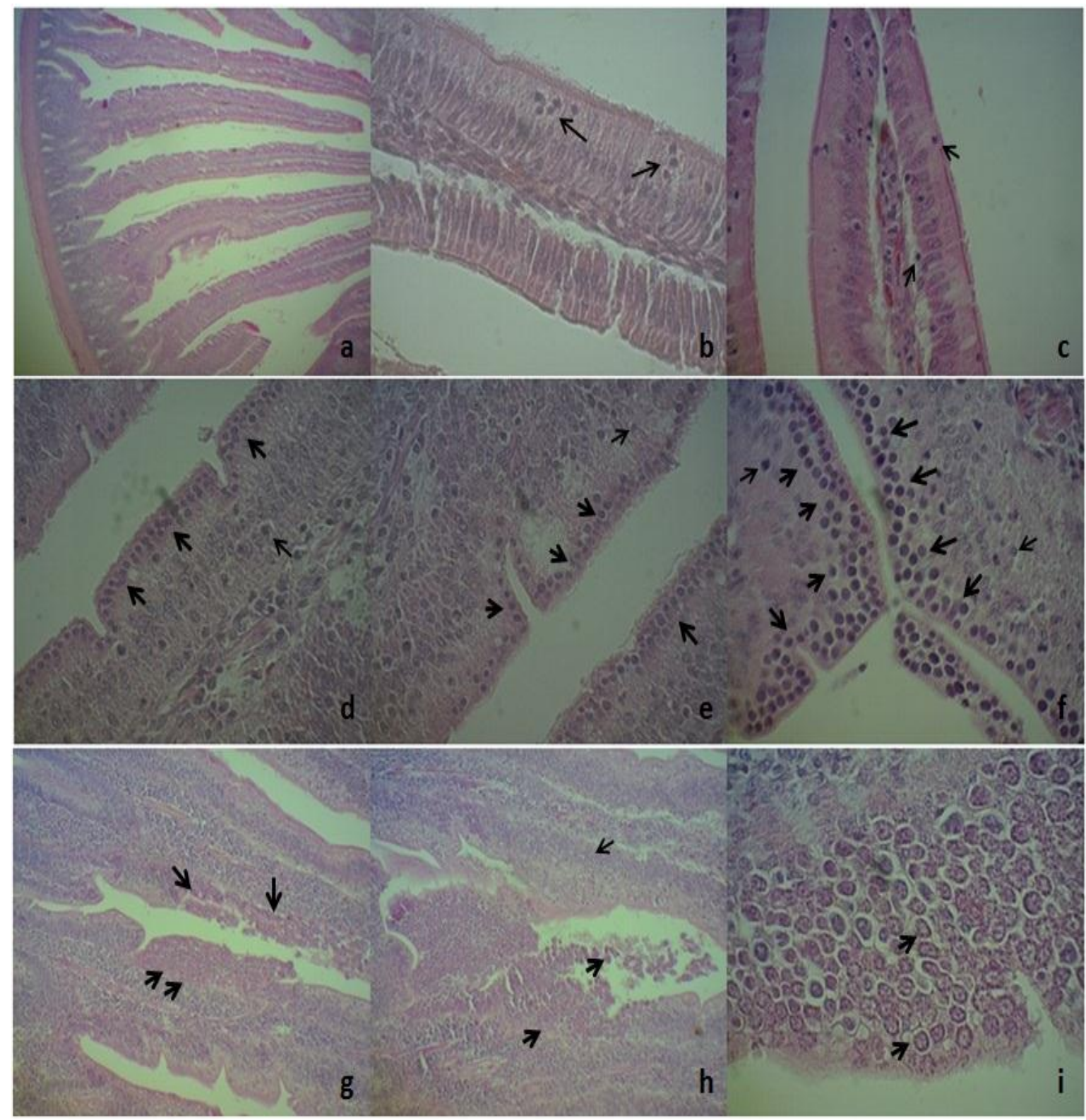

Figura 11 - Microscopia do epitélio intestinal em frangos de corte infectados com oocistos de Eimeria acervulina e submetidos a diferentes tratamentos: a) Mucosa intestinal no 0 dpi evidenciando integridade de epitélio e ausência de parasitismo (aumento de 40x); b-c) Mucosa intestinal no $4^{\circ}$ dpi evidenciando migração de linfócitos intraepiteliais (setas) para a região apical do enterócito; d-e-f) Epitélio intestinal no período de patência evidenciando alta quantidade de oocistos enfileirados na região apical do enterócito (seta espessa) e presença de linfócitos intraepiteliais na área infectada (aumento de 100x); g-h) Migração de linfócitos (seta fina) e presença de zigotos (seta espessa) na lateral da vilosidade ocasionando lesão de mucosa (aumento de 400x); i) Presença de zigotos no epitélio intestinal (aumento de 400x). Coloração Hematoxilina-eosina. 
Dickison (1941) relata que E. acervulina apresenta um alto grau de morbidade devido ao seu elevado potencial reprodutivo, sendo a espécie que produz maior quantidade de oocistos. De acordo com Morehouse e Mcguire (1958), o parasita invade as células epiteliais do duodeno, onde a infecção é mais severa, e avança até a parte média do intestino delgado causando destruição epitelial e consequente enterite. Terra et al. (2001), afirmam que as lesões provocadas no epitélio intestinal interferem negativamente nos índices zootécnicos dos frangos. De acordo com Freitas et al. (2008), alterações clínicas podem passar despercebidas nas granjas avícolas, tendo em vista o caráter subclínico da infecção e o grande número de animais acometidos, agravando ainda mais o problema.

No presente estudo, a análise histopatológica comprovou a ausência de parasitismo nos grupos 1 e 2. Entretanto, os animais dos grupos 3, 4, 5 e 6 apresentaram estruturas parasitárias distribuídas em toda a vilosidade intestinal (Figura 11 d-f.), principalmente nas criptas e glândulas, e evidente descamação de epitélio (Figura 11 g-h) e, conseqüentemente, atrofia de vilosidade, sendo ainda notória a presença de zigotos (Figura 11i) e oocistos recém formados na região apical dos enterócitos. Resultados semelhantes foram apresentados por Teixeira (2007), no tocante as lesões evidenciadas em frangos infectados com E. acervulina e suplementadas com betaína.

Verifica-se ainda (Figura 11) a presença e o aumento de linfócitos intraepiteliais estando distribuídos por toda a superfície do epitélio (Figura 11bc), caracterizando uma resposta do sistema imunológico do organismo no combate a infecção. O aumento do número e migração de linfócitos também foi observado na camada de tecido conjuntivo que dá suporte ao epitélio intestinal, sendo mais evidente no grupo 4. As lesões encontradas no grupo 4 foram semelhantes ao restante dos grupos infectados, porem menos intensas devido, provavelmente, ao efeito benéfico da preparação probiótica. Segundo Pereira (2007) existe, possivelmente, uma relação intima entre a função imunológica do intestino e a microbiota intestinal, contribuindo para uma melhor resposta contra o desenvolvimento da infecção parasitaria.

Uma alternativa na prevenção e tratamento de parasitoses que acometem frangos de corte e para substituição aos antibióticos consiste na utilização de microrganismos com propriedades probióticas. Preparações probióticas exercem ações benéficas ao hospedeiro, no intuito de excluir ou reduzir o crescimento de microrganismos potencialmente maléficos, agindo por meio da competição por nutrientes essenciais, produção e secreção 
de metabólitos antimicrobianos e eliminação de sítios receptores disponíveis (DALLOUL, 2003; OLIVEIRA-SEQUEIRA, 2008), tendo como vantagem, frente a utilização de antibióticos, o fato de não deixar resíduos na carne animal nem promover surgimento de patógenos resistentes, os quais demandam doses cada vez mais elevada de antibióticos para o controle da enfermidade.

Os benefícios oferecidos pelos probióticos, como o equilíbrio da microbiota intestinal do animal, estímulo do sistema imune do hospedeiro, competição por sítios ativos, evitando assim a fixação de microrganismos patógenos no trato digestório, produção de enzimas, entre outras funções, contribuem para que este seja um recurso empregado para o bem estar animal (PETRI, 2000; FINGER, 2008). A inclusão de microrganismos com propriedades probióticas na alimentação animal tem como objetivo o aumento da taxa de conversão alimentar, promovendo o ganho de peso animal. Porém a aplicação de uma suplementação probiótica na ração animal não está limitada apenas ao uso zootécnico, estendendo-se para uso veterinário no auxilio ao combate de enfermidades intestinais (DIBNER, 2005; JOUYBARI, 2009), conforme observado no presente trabalho.

\subsection{AVALIAÇÃO DE PARÂMETROS METABÓLICOS}

Além de comprometer a absorção de nutrientes pelo hospedeiro, infecções parasitárias localizadas na região do trato gastrointestinal animal podem também causar gastroenterites, perda de peso e retardo no desenvolvimento animal. Com a parede intestinal comprometida por ação parasitaria, dependendo do nível da lesão, os parâmetros bioquímicos são alterados devido a distúrbios ocorridos nas células que revestem a parece intestinal. Entretanto, a literatura cita que animais alimentados com ração contendo determinados microrganismos com função probiótica, possuem seus valores bioquímicos melhorados, sendo que os níveis de colesterol total, possivelmente, podem se apresentar baixos, dependendo da forma em que o tratamento é realizado.

Desta maneira, exames bioquímicos como proteínas totais, albumina, colesterol total, HDL, glicose e triglicerídeos foram realizados para determinar possíveis variações metabólicas em frangos de corte submetidos a diferentes tratamentos destacando-se o uso de uma preparação probiótica no combate a infecção causada por E. acervulina. Para tanto, foram utilizados grupos para controle negativo (grupos 1 e 2) e controle positivo (grupo 3), o qual foi infectado com $2 \times 10^{5}$ oocistos esporulados de E. acervulina, para fins 
comparativos; e grupos infectados com $2 \times 10^{5}$ oocistos esporulados de E. acervulina e submetidos a diferentes tipos de tratamentos com uma preparação probiótica composta por 4 cepas de Lactobacillus spp. (grupo 4, 5 e 6), cujos resultados encontram-se apresentados nas Tabelas.

Em testes bioquímicos rotineiramente realizados com animais infectados por $E$. acervulina, espera-se que os parâmetros bioquímicos, como os níveis proteínas, lipídeos e glicose, apresentem-se alterados devido ação parasitaria exercida nos enterócitos. Entretanto, animais tratados com determinadas preparações probiótica também apresentam alterações nos valores bioquímicos. Mas diferente das mudanças ocasionadas pela $E$. acervulina, algumas cepas com propriedades probiótica exercem um efeito benéfico nos valores bioquímicos do hospedeiro.

No presente trabalho, considerando os valores referentes aos paramentos em estudo (Tabela 1), observa-se que as alterações bioquímicas ocorreram no 4 dpi no que se refere apenas ao perfil lipídico. As concentrações de colesterol total dos grupos 3 e 4 foram superiores ao grupo 1, porém não deferiram estatisticamente entre si pelo teste $\mathrm{T}$ de student. Nota-se que a concentração de HDL relativo ao grupo 1 foi superior aos demais grupos experimentais; ao passo que as aves do grupo 2 apresentaram níveis elevados de HDL em relação aos grupos 3, 5 e 6. No tocante aos níveis de triglicerídeos observa-se que os animais do grupo 2 apresentaram valores inferiores quando comparados com as aves dos grupos 4 e 5, porém superiores aos animais do grupo 6. O aumento dos níveis dos parâmetros lipídicos ocorreu, possivelmente, devido ação do organismo das aves na mobilização oriunda do tecido adiposo no intuito de suprir a demanda das aves, considerando que essa diferença ocorreu no $4^{\circ} \mathrm{dpi}$, caraterizado pelo início do período patente, momento cujas aves infectadas apresentam maior irregularidade dos parâmetros metabólicos, devido ação do parasito nas células intestinais.

De acordo com resultados reportados por Allen (1984), acredita-se que a ausência de significância na variação dos parâmetros bioquímicos dos grupos em estudo ocorreu, possivelmente, devido a uma absorção compensatória realizada pelos enterócitos, em determinadas regiões íntegras do trato intestinal, na tentativa de suprir os locais afetados pelo parasito, mantendo os valores inalterados. Allen (1984) ainda observou um aumento no metabolismo celular demonstrando que o intestino delgado infectado é estimulado, em regiões especificas, a passar por alterações adaptativas compensatórias, para contrabalançar os efeitos na absorção de nutrientes ocasionada pela infecção. 
Tabela 1 - Parâmetros bioquímicos em frangos de corte infectados experimentalmente com oocistos de Eimeria acervulina e submetidos a diferentes tratamentos

\begin{tabular}{|c|c|c|c|c|c|c|}
\hline \multirow[t]{2}{*}{ Tratamento } & \multicolumn{5}{|c|}{ Dias de coleta de material } & \multirow[b]{2}{*}{28} \\
\hline & $\mathbf{0}$ & 4 & 7 & 14 & 21 & \\
\hline \multicolumn{7}{|c|}{ Proteínas Totais $(\mu \mathrm{g} / \mathrm{dL})$} \\
\hline G1 & 26,95 & 28,50 & 25,50 & 31,95 & 30,50 & 30,80 \\
\hline G2 & 26,25 & 26,15 & 24,15 & 32,65 & 34,50 & 30,60 \\
\hline G3 & 24,2 & 26,35 & 22,10 & 32,75 & 28,90 & 29,40 \\
\hline G4 & 26,00 & 28,70 & 23,15 & 35,20 & 31,55 & 32,35 \\
\hline G5 & 28,65 & 25,20 & 23,70 & 29,25 & 28,80 & 29,50 \\
\hline G6 & 27,90 & 23,25 & 21,95 & 31,25 & 28,45 & 29,65 \\
\hline \multicolumn{7}{|c|}{ Albumina (g/dL) } \\
\hline G1 & 1,60 & 1,74 & 1,78 & 1,82 & 1,71 & 1,78 \\
\hline G2 & 1,61 & 1,68 & 1,59 & 1,82 & 1,77 & 1,82 \\
\hline G3 & 1,61 & 1,72 & 1,47 & 1,90 & 1,74 & 1,67 \\
\hline G4 & 1,77 & 1,87 & 1,45 & 1,94 & 1,83 & 1,86 \\
\hline G5 & 1,81 & 1,74 & 1,57 & 1,78 & 1,79 & 1,62 \\
\hline G6 & 1,83 & 1,66 & 1,46 & 1,83 & 1,76 & 1,62 \\
\hline \multicolumn{7}{|c|}{ Colesterol total $(\mathrm{mg} / \mathrm{dL})$} \\
\hline G1 & 103,15 & 95,9 & 87,95 & 105,70 & 115,10 & 91,20 \\
\hline G2 & 136,80 & $*$ & 101,00 & 121,65 & 100,25 & 97,40 \\
\hline G3 & 131,40 & 107,65 & 93,75 & 119,80 & 122,35 & 99,55 \\
\hline G4 & 120,15 & 123,45 & 96,60 & 112,20 & 138,65 & 102,00 \\
\hline G5 & 130,65 & 105,35 & 90,28 & 118,00 & 103,85 & 104,25 \\
\hline G6 & 145,90 & 95,55 & 90,10 & 114,70 & 106,40 & 93,35 \\
\hline \multicolumn{7}{|c|}{ HDL (mg/dL) } \\
\hline G1 & 73,20 & 133,10 & 80,15 & 57,25 & 54,30 & 60,90 \\
\hline G2 & 102,65 & 123,80 & 57,95 & 60,90 & 65,90 & 66,20 \\
\hline G3 & 88,75 & 91,40 & 56,25 & 59,95 & 61,25 & 58,60 \\
\hline G4 & 69,85 & 94,35 & 49,65 & 59,90 & 74,20 & 59,25 \\
\hline G5 & 75,45 & 74,50 & 56,60 & 55,95 & 50,65 & 49,65 \\
\hline G6 & 88,10 & 83,80 & 46,35 & 57,60 & 52,65 & 45,00 \\
\hline \multicolumn{7}{|c|}{ Glicose (mg/dL) } \\
\hline G1 & 345,45 & 265,60 & 272,25 & 270,10 & 263,15 & 260,00 \\
\hline G2 & 247,90 & 266,05 & 273,25 & 271,55 & 246,95 & 242,50 \\
\hline G3 & 307,35 & 269,85 & 292,35 & 256,00 & 278,45 & 234,70 \\
\hline G4 & 263,45 & 276,55 & 294,70 & 241,90 & 286,10 & 274,80 \\
\hline G5 & 287,80 & 286,85 & 266,75 & 228,55 & 251,45 & 266,80 \\
\hline G6 & 273,20 & 286,15 & 303,80 & 242,40 & 268,65 & 248,35 \\
\hline \multicolumn{7}{|c|}{ Triglicerídeos (mg/dL) } \\
\hline G1 & 98,90 & $*$ & 68,20 & 105,05 & 42,50 & 58,10 \\
\hline G2 & 86,60 & 55,30 & 56,45 & 106,20 & 48,05 & 64,85 \\
\hline G3 & 105,60 & 60,35 & 63,70 & 92,70 & 76,55 & 76,00 \\
\hline G4 & 68,75 & 83,30 & 51,95 & 90,55 & 77,65 & 98,90 \\
\hline G5 & 127,40 & 72,10 & 100,05 & 91,65 & 46,95 & 88,30 \\
\hline G6 & 102,25 & 33,55 & 64,25 & 110,6 & 49,15 & 82,15 \\
\hline
\end{tabular}

* Amostras perdidas. 
Referente aos demais testes bioquímicos, os valores obtidos foram analisados estatisticamente e não apresentaram significância (p>0,05) nos valores em comparação aos demais grupos durante todo o período experimental. De acordo com Allen (1984), acreditase que a ausência de significância na variação dos parâmetros bioquímicos dos grupos em estudo ocorreu, possivelmente, devido a uma absorção compensatória realizada pelos enterócitos, em determinadas regiões íntegras do trato intestinal, na tentativa de suprir os locais afetados pelo parasito, mantendo os valores inalterados. Resultados semelhantes foram reportados por Allen (1984) e Danforth (1998) que, ao avaliar a atividade mitocondrial de enterócitos, observou um aumento no metabolismo celular demonstrando que o intestino delgado infectado é estimulado, em regiões especificas, a passar por alterações adaptativas compensatórias.

Lesões procedentes da ação de parasitas no trato gastrointestinal animal, interferem na absorção de nutrientes, provocando distúrbios no metabolismo, decorrentes da destruição do epitélio, porém a carga parasitária presente no animal e a resistência do mesmo frente à infecção, determinam o prejuízo causado no organismo. Em aves infectadas por E. acervulina, os danos causados pela infecção estão situados na região proximal do intestino, no qual se observa reação inflamatória, devido à ação do parasita na destruição dos enterócitos. Teixeira (2007), afirma que mudanças ocorridas devido à ação da E. acervulina nos enterócitos culminam em consequências importantes no transporte de nutrientes ao longo do trato digestivo, causando depressão da capacidade absortiva, ou má absorção da mucosa, prejudicando a entrada dos nutrientes.

Teixeira (2007), ao utilizar betaína no tratamento de aves infectadas com $E$. acervulina, relatou ausência de variação significativa nos níveis de proteínas totais nos animais. Jouybari (2009), utilizando Pseudomonas putida e Pantoea agglomeran como agentes probióticos em aves, observou efeito significativo na redução da taxa do colesterol e triglicerídeos. Entretanto, Kanashiro (2001) afirmou que o uso de uma preparação probiótica em frango de corte não alterou os níveis de colesterol de forma significativa. Por outro lado, segundo Abdulrahim et al. (1996), ao tratar aves com Lactobacillus acidophilus, houve uma redução de $55 \%$ na concentração plasmática do colesterol, porém essa redução só ocorreu após 12 semanas de administração contínua da cultura bacteriana nos animais. 
Freitas (2008) relatou que aves infectadas com uma carga parasitária de $10^{6}$ oocistos de E. acervulina apresentaram quadro de hipoglicemia, o qual se manteve durante maior parte do período experimental devido a alta carga parasitária, gerando forte inflamação no epitélio intestinal e comprometendo a absorção de glicose, o que também foi relatado por Freeman (1970). Em quadros de hipoglicemia, observam-se níveis elevados de glucagon, hormônio secretado pelo pâncreas, mobilizando o glicogênio hepático na tentativa de restabelecer a homeostase da glicose (ALLEN, 1984; FREITAS, 2008). Esta característica fisiológica provavelmente explica a estabilidade da concentração de glicose nos grupos em estudo do presente trabalho.

\subsection{AVALIAÇÃO DO DESEMPENHO ZOOTÉCNICO}

Os valores referentes ao peso vivo e peso de carcaça com vísceras comestíveis dos animais distribuídos nos diferentes grupos experimentais, o que permitiu avaliar o desempenho zootécnico, estão representados nas Figuras 12 e 13 e Tabela 2. A análise estatística (test $\mathrm{T}$ ) destes resultados revelou que estes não foram diferentes significativamente, tanto para média de peso vivo quanto para peso carcaça com vísceras comestíveis $(\mathrm{p}>0,05)$. Frente a esta observação, verifica-se que preparação probiótica em estudo não contribuiu de forma significativa para o desempenho zootécnico dos animais.

Segundo Jouybari et al. (2009), aves tratadas com uma dieta contendo microrganismos probióticos apresentaram uma taxa de conversão alimentar melhor comparados as aves alimentadas sem o aditivo probiótico. O mesmo foi observado por Cardoso (2006), por meio da adição de Bacillus subtilis na dieta frangos, melhorando a conversão alimentar. Edens (2003) afirmou que ao adicionar B. subtilis na dieta de frangos de corte não ocorre alteração no ganho de peso animal, contudo a conversão alimentar foi melhor, quando comparada aos animias não suplementados com microrganismos probióticos, porém, o mesmo não foi evidenciado no presente trabalho. Freitas (2006) relatou que animais infectados com E. acervulina, mesmo após o término do período patente, apresentaram um desempenho zootécnico prejudicado, onde as aves infectadas apresentaram baixo ganho de peso quando comparadas aos animais saudáveis.

No presente estudo, os animais infectados apresentaram perda de peso durante a infecção, sendo que após o término do ciclo de vida do parasita, as aves ganharam peso. Possivelmente, isso ocorreu devido a uma absorção compensatória dos nutrientes exercida 
por regiões saudáveis ou pouco danificadas pelo parasita, conferindo um determinado ganho de peso mesmo os animais estando infectados.

De acordo com Faria (2009), ao avaliar o efeito de diferentes antibióticos, probióticos e suas combinações sobre o desempenho zootécnico e rendimento de carcaça de frangos de corte, possivelmente, a ausência de resposta positiva aos tratamentos administrados nas aves, em termos de ganho de peso, foi devido as boas condições de higiene do ambiente, do estado sanitário dos animais, da eficiência de manejo, entre outros. Este autor ressalta ainda que o grau de resposta aos tratamentos é inversamente relacionado ao bem-estar dos animais, ou seja, quanto maior o bem estar animal, menor seria sua resposta ao tratamento, devido a ausência de desafio para o animal, portanto, é possível que resultados obtidos no campo sejam maiores. Pedroso et al. (2003) verificaram que frangos de corte criados em gaiolas não responderam à utilização de antibiótico. Já os criados em piso apresentaram melhores ganho de peso corporal e conversão alimentar quando alimentados com antibióticos, em comparação com ração sem aditivo promotor de crescimento.

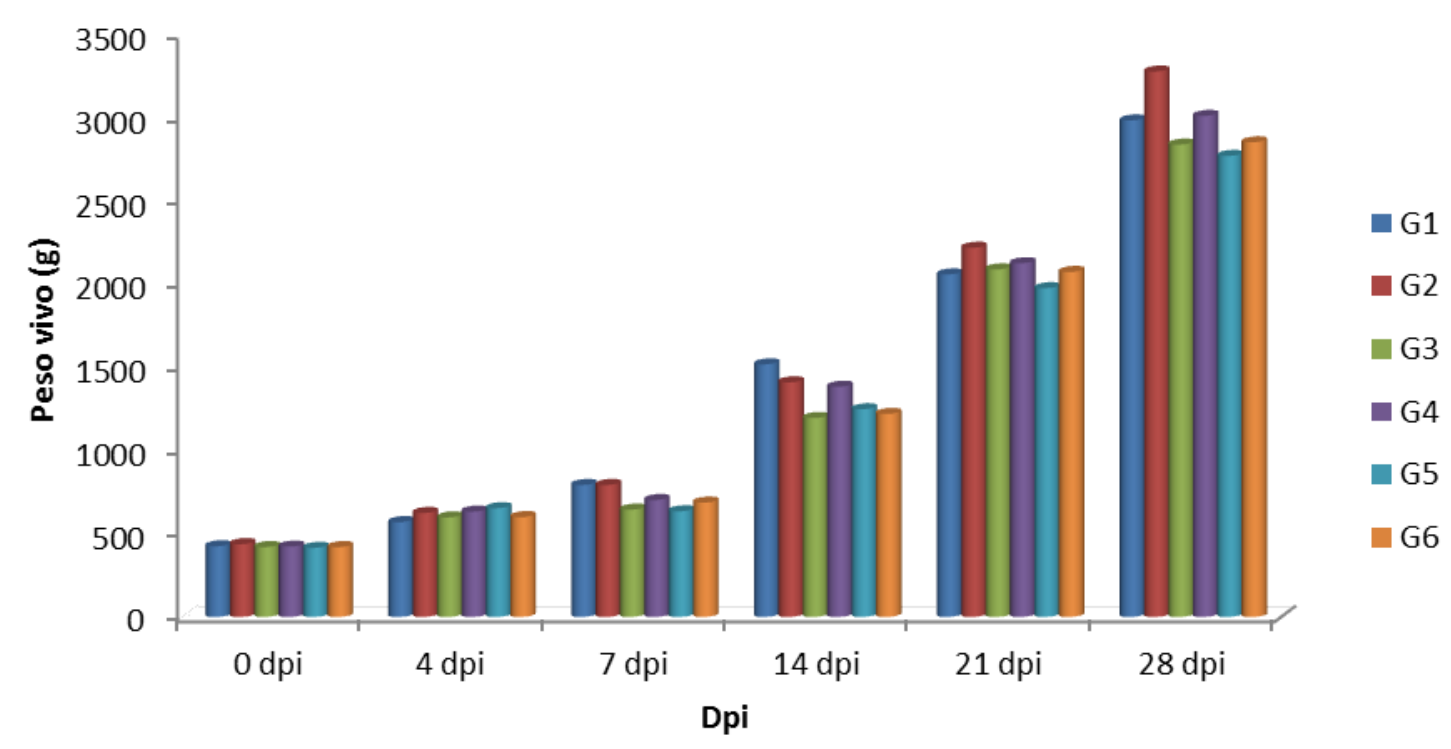

Figura 12 - Média do peso vivo em frangos de corte, linhagem Cobb, infectados experimentalmente com oocistos esporulados de Eimeria acervulina e submetidos a diferentes tratamentos. 


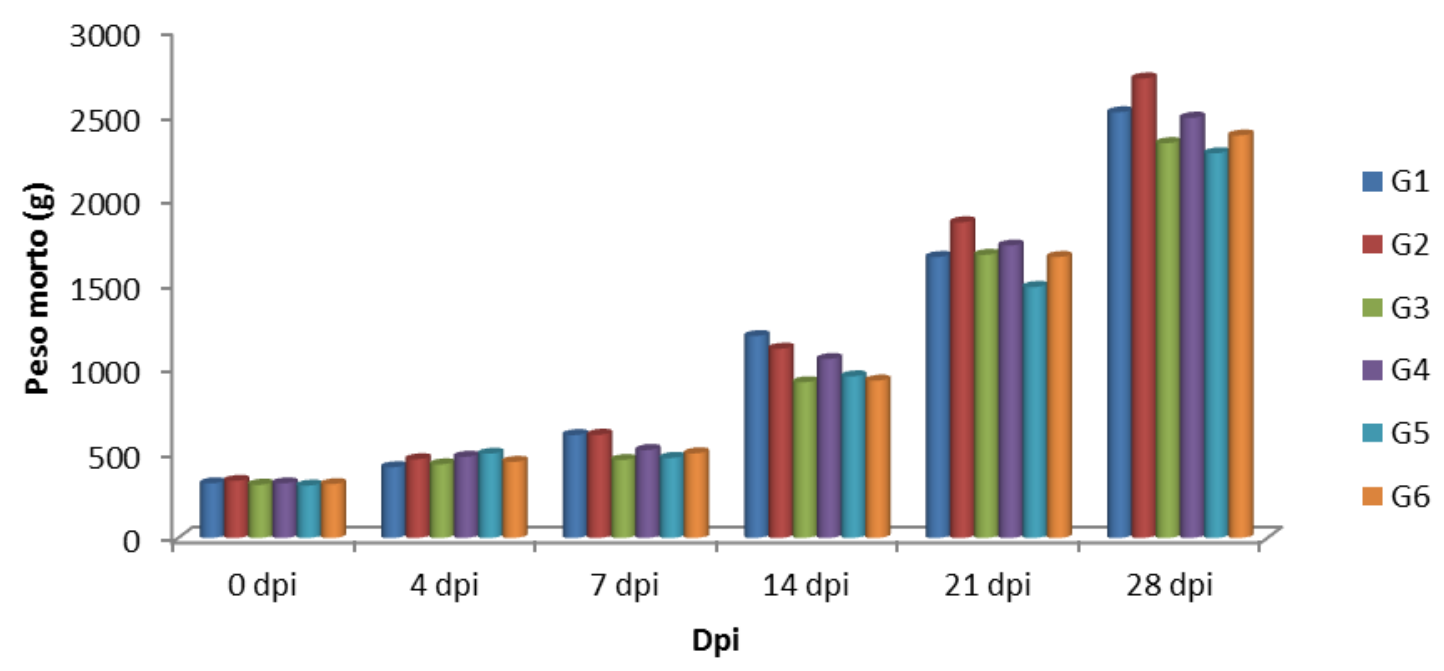

Figura 13 - Média do peso morto em frangos de corte, linhagem Cobb, infectados experimentalmente com oocistos esporulados de Eimeria acervulina e submetidos a diferentes tratamentos.

Em experimento realizado por Loddi (2000), verificou-se diferença significativa no rendimento de carcaça, por meio da adição de probiótico na ração de frangos de corte. Entretanto, os valores referentes ao rendimento de carcaça do presente estudo (Tabela 2), tanto para os animais com 21 dias de vida (7dpi), quanto para os com 42 dias de vida (28Dpi) não resultaram em diferença significativa, quando analisados pelo test-T. O mesmo foi evidenciado por Corrêa (2004), que também ao utilizar uma preparação probiótica na alimentação de frangos destinados a corte, relatou ausência de diferença significativa no rendimento da carcaça. Resultados semelhantes foram também observados por Pelicano (2004) e por Otutumi (2009), que ao adicionar probiótico na ração de codornas de corte observou ausência de significância no rendimento de carcaça.

Nos trabalhos realizados por Maiorka et al. (2001) e Corrêa et al. (2003), avaliando Bacillus subtilis, Santos et al. (2004), avaliando Bacillus lincheniformis e Bacillus subtilis e Pelicano et al. (2005), avaliando Bacillus subtilis; Lactobacillus acidophilus, Lactobacillus casei, Streptococcus lactis, Streptococcus faecium, Bifidobacterium bifidum e Aspergillus oryzae como probióticos, verificou-se ausência de significância no rendimento de carcaça total e de partes individuais em frangos de corte em comparação com a ração-controle, sem aditivos. Faria (2009), ao testar diferentes preparações probióticas, como alternativa ao uso de antibiótico, não observou significância nos 
resultados referentes ao rendimento de carcaça total e de partes (peito, coxas, sobrecoxas e asas) nos diferentes grupos avaliados. Dessa forma, Faria (2009) afirma que, com os resultados achados em estudos realizados e com resultados obtidos na literatura científica, à dados suficientes para inferir que a utilização desses probióticos na alimentação animal não aumenta necessariamente os parâmetros do desempenho zootécnico referentes ao rendimento de carcaça, como a composição da ração, idade ou sexo do animal.

Tabela 2 - Rendimento de carcaça de frangos de corte, linhagem Cobb, aos 21 e 42 dias de vida, infectados experimentalmente com oocistos esporulados de Eimeria acervulina e submetidos a diferentes tratamentos.

\begin{tabular}{|c|c|c|c|c|}
\hline Tratamentos & Dias de vida & $\begin{array}{l}\text { Peso vivo } \\
\text { médio }\end{array}$ & Peso carcaça & $\begin{array}{l}\text { Rendimento de } \\
\text { Carcaça }\end{array}$ \\
\hline \multirow[b]{2}{*}{ G1 } & $21 *$ & $793 \mathrm{~g}$ & $608 \mathrm{~g}$ & $76 \%$ \\
\hline & $42 * *$ & $2983 \mathrm{~g}$ & $2515 \mathrm{~g}$ & $84 \%$ \\
\hline \multirow[b]{2}{*}{ G2 } & $21 *$ & $793 \mathrm{~g}$ & $610 \mathrm{~g}$ & $77 \%$ \\
\hline & $42 * *$ & $3277 \mathrm{~g}$ & $2715 \mathrm{~g}$ & $83 \%$ \\
\hline \multirow{2}{*}{ G3 } & $21^{*}$ & $645 \mathrm{~g}$ & $503 \mathrm{~g}$ & $78 \%$ \\
\hline & $42 * *$ & $2838 \mathrm{~g}$ & $2333 \mathrm{~g}$ & $83 \%$ \\
\hline \multirow{2}{*}{ G4 } & $21^{*}$ & $703 \mathrm{~g}$ & $520 \mathrm{~g}$ & $74 \%$ \\
\hline & $42 * *$ & $3010 \mathrm{~g}$ & $2483 \mathrm{~g}$ & $83 \%$ \\
\hline \multirow[b]{2}{*}{ G5 } & $21^{*}$ & $635 \mathrm{~g}$ & $473 \mathrm{~g}$ & $74 \%$ \\
\hline & $42 * *$ & $2770 \mathrm{~g}$ & $2273 \mathrm{~g}$ & $82 \%$ \\
\hline \multirow{2}{*}{ G6 } & $21^{*}$ & $688 \mathrm{~g}$ & $500 \mathrm{~g}$ & $73 \%$ \\
\hline & $42 * *$ & $2853 \mathrm{~g}$ & $2378 \mathrm{~g}$ & $83 \%$ \\
\hline
\end{tabular}

* - Referente a 7dpi

** - Referente a 28 dpi 
Dentre as espécies do gênero Eimeria spp. destaca-se a $E$. acervulina que, segundo Morehouse e Mcguire (1958), se manifesta, frequentemente, na forma subclínica ocasionando prejuízos na conversão alimentar e diminuição no crescimento e ganho de peso das aves. Com a adição de uma preparação probiótica na dieta animal, estima-se uma melhoria nos valores zootécnicos, por meio de uma melhora da conversão e eficiência alimentar. O mesmo não foi observado no presente trabalho (Tabela 3), sendo possível verificar que os animais submetidos a diferentes tratamentos, apresentaram valores de consumo de ração, ganho de peso, conversão e eficiência alimentar não apresentaram valores significativos estatisticamente $(\mathrm{P}>0,05)$, demonstrando que a preparação probiótica em estudo não contribuiu positivamente para o desempenho zootécnico dos animais, considerando inviável a utilização dessa preparação probiótica para fins zootécnicos.

Corrêa (2003) relatou que os resultados de desempenho das aves mostram que as variáveis consumo de ração, ganho de peso e conversão alimentar não foram afetados $(\mathrm{P}>0,05)$ pelo uso de probióticos na ração. Resultados semelhantes foram obtidos nos trabalhos realizados por Souza et al. (1993), Cavalcanti et al. (1996), Henrique et al. (1998), Zuanon et al. (1998), Araújo et al. (2000), Loddi et al. (2000) e Moreira et al. (2002) ao pesquisarem adição de probiótico na alimentação de aves, evidenciando a ausência da melhora da eficiência no desempenho das aves, referente as cepas utilizadas.

No trabalho desenvolvido para avaliar desempenho zootécnico em frangos de corte, Araújo (2007) ao utilizar diferentes tipos de cama e densidade populacional obteve uma conversão alimentar média de 2.06. Lana (2001) ao estudar o efeito da densidade e de programas de alimentação sobre o fator conversão alimentar, em aves com 1 a 42 dias de idade, obteve médias de 1,86 e 1,90, não obtendo resultados estatisticamente significâncos entre os programas de alimentação avaliados. Santos (2004) ao avaliar o desempenho zootécnico de frangos de corte de 1-42 dias de vida, submetidos a dietas com diferentes aditivos, apresentou em grupo controle uma conversão alimentar de 1,98, sendo que para os grupos tratados com probióticos a conversão alimentar ficou entre 1,99 à 2,03 em frangos de corte. No presente trabalho, os valores de conversão alimentar obtidos em frangos de corte no período entre 14 e 42 dias de vida, corresponderam a 1,66 para o grupo controle e 1,62 para o grupo tratado com probióticos, cujos resultados não diferem estatisticamente entre si. 
Tabela 3 - Desempenho zootécnico de frangos de corte, linhagem Cobb, com 42 dias de vida, infectados experimentalmente com oocistos esporulados de Eimeria acervulina e submetidos a diferentes tratamentos com preparação probiótica de Lactobacillus spp..

\begin{tabular}{|c|c|c|c|c|c|}
\hline Tratamentos & $\mathbf{C R}$ & GP & $\mathbf{C A}$ & EA & GD \\
\hline G1 & $4152,81 \mathrm{~g}$ & $2511,88 \mathrm{~g}$ & 1,66 & $60 \%$ & $89,71 \mathrm{~g}$ \\
\hline G2 & $4140,88 \mathrm{~g}$ & $2565,75 \mathrm{~g}$ & 1,62 & $62 \%$ & $91,63 \mathrm{~g}$ \\
\hline G3 & $3952,31 \mathrm{~g}$ & $2319,83 \mathrm{~g}$ & 1,71 & $59 \%$ & $82,85 \mathrm{~g}$ \\
\hline G4 & $4025,30 \mathrm{~g}$ & $2261,72 \mathrm{~g}$ & 1,79 & $56 \%$ & $80,78 \mathrm{~g}$ \\
\hline G5 & $3748,25 \mathrm{~g}$ & $2116,25 \mathrm{~g}$ & 1,77 & $57 \%$ & $75,58 \mathrm{~g}$ \\
\hline G6 & $3802,93 \mathrm{~g}$ & $2238,38 \mathrm{~g}$ & 1,71 & $59 \%$ & $79,94 \mathrm{~g}$ \\
\hline
\end{tabular}

- $\mathbf{C R}=$ : Consumo de ração ; GP = Ganho de peso ; CA = Conversão alimentar EA = Eficiência alimentar (EA); GD = Média do ganho de peso diário. 


\section{CONCLUSÕES}

Os resultados obtidos no presente trabalho permitem concluir que:

- O "pool” de microrganismos probióticos avaliado mostrou ação moderada no combate à infecção provocada par Eimeria acervulina em frangos de corte, reduzindo em até 39,12\% a quantidade de oocistos excretados para o meio.

- A infecção causada pela Eimeria acervulina surtiu significância apenas no tocante aos exames bioquímicos referentes a colesterol total, HDL e triglicerídeos nas aves no $4^{\circ}$ dpi, contudo se normalizou nos demais dias de experimento.

- O uso da preparação probiótica não resultou em efeito significativo no tocante aos exames bioquímicos realizados, bem como sobre desempenho zootécnico dos animais, possivelmente devido a origem das cepas avaliadas ser da microbiota de animal mamífero e não de aves.. 


\section{SUGESTÕES PARA TRABALHOS FUTUROS}

Aumentar o número de animais no experimento possibilitando assim uma análise estatística mais consistente, permitindo um melhor dimensionamento dos efeitos causados pelo patógeno.

Avaliar o efeito preventivo provocado pelos microrganismos probióticos, tendo em vista que os resultados demonstraram que o uso terapêutico não reduziu a carga parasitária do patógeno no hospedeiro.

Avaliar novas preparações probióticas constituídas por cepas de Lactobacillus que tenham sua origem na microbiota de aves. 


\section{REFERÊNCIAS}

ABDULRAHIM, S.M., HADDADIN, M.S.Y., HASHLAMOUN, E.A.R., et al. The influence of Lactobacillus acidophilus and bacitracina on layer performance of chickens and cholesterol content of plasma and egg yolk. British Poultry Science, Edinburgh, v.37, n.2, p.341-346, 1996.

ABEF. Associação brasileira dos produtores e exportadores de frango. Avicultura brasileira em 2010: Exportações e produção. Disponível em:

$\langle$ http://www.abef.com.br/noticias_portal/exibenoticia.php?notcodigo=2389> Acesso em $16 / 03 / 2011$.

ABEF. Associação brasileira dos produtores e exportadores de frango. Consumo Brasileiro de Carne de Frango. Disponível em:

<http:// www.abef.com.br/estatísticas/mercadoInterno/historico > Acesso em 17/12/2009.

ABEF. Associação brasileira dos produtores e exportadores de frango. Produção Mundial de Carne de Frango.

<http:// www.abef.com.br/Estatisticas/MercadoMundial/MercadoMundial.php> Acesso em 17/12/2009.

AHID, S. M. M. Apostila Didática em Protozoologia Veterinária. 2009.

ALBINO, L. F. T.; FERES, F. A.; DIONOZIO, M. A.; ROSTAGNO, H. S.; VARGAS JÚNIOR, J. G.; CARVALHO, D. C. O.; GOMES, P. C.; COSTA, C. H. R. Uso de prebióticos a base de mananoligossacarídeo em rações para frangos de corte. Revista Brasileira de Zootecnia, v. 35, n. 3, p.742-749, 2006.

ALBINO, L.F.T; TAVERNARI, F.C. Produção e manejo de frangos de corte. Viçosa: UFV, 2008. $88 \mathrm{p}$

ALBUQUERQUE, R. Antimicrobianos como aditivos zootécnicos promotores de crescimento. In: PALERMO NETO, J.; SPINOSA. H. S.; GÓRNIAK, S. L. Farmacologia aplicada à avicultura. São Paulo: Roca, 2005. cap. 9, p. 149-159.

ALAK, J.I. et al. Supplementation with Lactobacillus reuteri or L. acidophilus reduced intestinal shedding of Cryptosporidium parvum oocysts in immunodeficient C57BL/6 mice. Cellular and molecular biology, v.45, n.6, p.855-863, 1999.

ALLEN P. C., FETTERER R. H. Recent advances in biology and immunobiology of Eimeria species and in diagnosis and control of infection with these coccidian parasites of poultry. Clinical Microbiology Reviews, v15, n1, p.58-65, 2002.

ALLEN, P.C.; MCMURTRY, J.P. Changes in pancreatic hormones associated with coccidiosis. Poultry Science, v. 63, n. 6, p.1129-1135, 1984 
ANUÁRIO DA AVICULTURA INDUSTRIAL. O avanço da utilização de vacinas e o uso de prébióticos e probióticos em substituição aos aditivos e promotores de crescimento devem ser as estratégias usadas no combate à coccidiose nos próximos anos. n. 1081/2000. [online] Disponível em:

<www.url.http://www.aviculturaindustrial.com.br> Acesso em 14 de janeiro de 2010.

ARAUJO, J. A.; SILVA, J. H. V.; AMÂNCIO, A. L. L.; LIMA, M. R.; LIMA, C. B. Uso de aditivos na alimentação de aves. Acta Veterinaria Brasílica, v. 1, n. 3, p. 69-77, 2007.

AVISITE. Carne de frango: os 10 principais importadores do Brasil em 2011. Disponível em: <http://www.avisite.com.br/noticias/default.asp?codnoticia=12301>. Acesso em $22 / 08 / 2011$.

BIOVET - Imprensa. Avicultura. Disponível em:

<http://www.biovet.com.br/site/start/index.asp?categoria=8\&subcategoria=2\&ling=pt\&Id

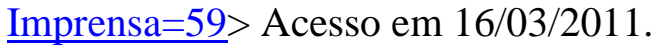

BRAZILIANCHICKEN - A Industria Avícola: História. Disponível em:

$\langle$ http://www.brazilianchicken.com.br/industria-avicola/historia-avicola.php $>$ Acesso em $16 / 03 / 2011$.

BRITO, A. Unicamp cria substâncias para controle de doença de granja. Jornal da Unicamp, Campinas, 215 ed., jun. 2003. Disponível em:

<http:// www.unicamp.br/unicamp/unicamp_hoje/ju/junho2003/ju215pg03.html >, acesso em: $17 / 12 / 2009$.

BUTOLO, J. E. Uso de aditivos na alimentação das aves: frangos de corte. In: SIMPÓSIO SOBRE AS IMPLICAÇÕES SÓCIO-ECONÔMICAS DO USO DE ADITIVOS NA NUTRIÇÃO ANIMAL, 1999, Piracicaba. Anais... Piracicaba: CBNA, p. 85-94, 1999.

CARDOZO, S.; YAMAMURA, M.. Identificação de espécies de Eimeria sp e avaliação do escore de lesões intestinais entre frangos vacinados e tratados com anticoccidiano, produzidos no sistema colonial/caipira. Semina: Ciências Agrárias, v.27, n.2, p.261-270, 2006.

CARDOZO, E.C. Utilização de probiótico (Bacillus subtilis) como aditivo alimentar em dietas de frangos. 2006. 55 f. Dissertação (Mestrado em Tecnologia de Alimentos). Universidade Federal do Paraná, Curitiba.

CARVALHO, T.A. Avaliação de dietas com glutamine e glicina para pintos de corte contendo diferentes relações treonina:lisina. Dissertação (Mestrado em Zootecnia). Universidade federal de Viçosa, Viçosa-MG, 2009.

CASTAÑÓN, C. A. B. Análise e reconhecimento digital de formas biológicas para o diagnóstico automático de parasitas do gênero Eimeria. Tese (Doutorado) Universidade de São Paulo. Instituto de Ciências Biomédicas. Área de concentração: Bioinformática. Linha de pesquisa: Processamento digital de imagens. São Paulo, 2006. 
CASTRO, A.G.M. de. Situação atual da coccidiose no Brasil. Importância econômica. In: SIMPÓSIO INTERNACIONAL DE COCCIDIOSE, 1994. Santos, SP, FACTA. Anais... FACTA, 1994. p. 45-54.

CHAPMAN, H.D.; FERNANDES, D.L.; DAVISON, T.F. A comparison of the effects of infection with Eimeria maxima and dietary restriction on weigth gain, plasma metabolites and liver glycogen in the immature fowl, Gallus domesticus. Parasitology, v.84, p.205213, 1983.

COCCIDIA. Eimeria spp. Disponível em: <http://www.coccidia.icb.usp.br/disciplinas/BMP222/aulas/Aula_Pratica_1_Eimeria.pdf>. Acesso em: 23/08/2011.

COELHO, M. D. G. Avaliação do uso de probióticos no combate a infecção causada por Ancylostomidae em cães (Canis familiaris) naturalmente infectados.. Tese (Doutorado em Biotecnologia Industrial) - Escola de Engenharia de Lorena USP. LorenaSP, 2010.

CONWAY, D.P.; MCKENZIE, M.E. Poultry coccidiosis: Diagnostic and testing procedures. $3^{\text {rd }}$ ed. Local: Blackwell, 2007. p.164.

COPPOLA, M. M.; TURNES, C. G. Probióticos e resposta imune. Ciência Rural, v. 34, n. 4, 2004.

CORNELI, J. Avaliação de promotores de crescimento alternativos em substituição aos convencionais sobre o desempenho, característica de carcaça e morfologia intestinal em frangos de corte. 2004. 59 f. Dissertação (Mestrado em Zootecnia) Universidade Federal de Santa Maria, Rio Grande do Sul, 2004.

CORRÊA, G. S. S. Efeito de antibiótico e probiótico sobre o desempenho e rendimento de carcaça de frangos de corte. Arquivo Brasileiro de Medicina Veterinária e Zootécnica, v. 55, n. 4, p. 1-9, 2003.

CORRÊA, G. S. S.; GOMES, A. V. C.; CORREAA, A. B.; et al. Efeito de antibiótico e prebiótico sobre o desempenho e rendimento de carcaça de frangos de corte. Arquivo Brasileiro de Medicina Veterinária e Zootecnia, V.55, n.55, n.4, p.467-473, 2003.

COSTA, C. A. F. Utilização de marcadores moleculares no monitoramento da coccidiose aviária. Avicultura Industrial, p. 12 - 16, 2001

COSTA, C. A. F. Controle de coccidiose: Possíveis avanços. In: Simpósio de Sanidade Avícola da UFSM, 2002, Santa Maria, RS. Anais... Concórdia - SC: Embrapa Suínos e Aves, 2002. v. 1. p. 36-47.

CURRENT,W., UPTON, S., E LONG, P. Taxonomy and life cycles. In: LONG P.L. (Ed.) Coccidiosis of Man and Domestic Animals. Boca Raton, FL: CRC Press, Inc. Chap. 1, p.1-16. 
DALLOUL, R.A. et al. Enhanced mucosal immunity against Eimeria acervulina in broilers fed a Lactobacillus - based probiotic. Poultry Science, v.82, n.1, p.62-66, 2003

DANFORTH, H. D. Use of live oocyst vaccines in the control of avian coccidiosis: experimental studies and field trials. International Journal for Parasitology, v.28 p.1099-1109, 1998.

DIBNER, J. J.; RICHARDS, J. D. Antibiotics growth promoters in agriculture: history and mode of action. Poultry Science, v. 84, n.4, p. 634-643, 2005.

DICKINSON, E.M. The effects of variable dosages of sporulated Eimeria acervulina oocysts on chickens. Poultry Science, v. 20, n. 1, p.413-424, 1941.

DIONIZIO, M. A.; BERTECHINI, A. G.; KATO, R. K.; TEIXEIRA, A. S. Prebióticos como promotores de crescimento para frangos de corte - desempenho e rendimento de carcaça. Ciência Agrotécnica, Lavras. p. 1580-1587, Edição Especial, dez., 2002.

DUBREMETZ, J. F. Apical organelles (rhoptries, micronemes, dense granules) and host cell invasion by coccidian: what do we know now? In: COCCIDIOSIS CONFERENCE. 6., 1993, Ontario. Proceeding of the VIth Coccidiosis Conference. p. 3-9.

EDENS, F. W. An alternative for antibiotic use in poultry: probiotic. Revista Brasileira de Ciência Avícola. v.5, n.2, p.75-97, 2003.

ERICKSON, K. L.; HUBBARD, N. E. Probiotic immunomodulation in health and diseases. The Journal of Nutrition, v. 130, p. 403-409, 2000.

FARIA, D.E.; HENRIQUE, A.P. F.; NETO, R. F. MEDEIROS, A. A. ; JUNQUEIRA, O. M.; FARIA D.E. DE. Alternativa ao uso de antibióticos como promotores de crescimento para frangos de corte. Ciência Animal Brasileira, v. 10, n. 1, p. 18-28, jan./mar. 2009.

FERKET, P. R. Manutenção da saúde intestinal em um mundo sem antibióticos. In: RONDA LATINO AMERICANA DA ALLTECH, 13. 2003, Campinas. Anais... Campinas: Alltech, p. 26-39, 2003.

FERNANDO, M. A. Eimeria: Infections of the intestine. In: LONG, P. L. Coccidiosis of man and domestic animals. Florida: CRC Press Boca Raton, 1990. Cap. 4, p. 63-75 FERREIRA, A. J. P.; PIZARRO, L. D. C. R.; LEME, I. L. Probióticos e prebióticos. In: SPINOSA, H. S.; GORNIAK, S. L.; BERNARDI, M. M. Farmacologia aplicada à medicina veterinária. 3. ed. Rio de Janeiro: Ed. Guanabara Koogan, 2002. p. 574-578.

FERREIRA. A.P., ASTOLFI-FERREIRA, C.S. Medidas inespecíficas para o controle bacteriano. In: Simpósio Brasil Sul de Avicultura, Chapecó, 2006, anais. p. 56-66, 2006.

FERREIRA, F. A. B.; KUSSAKAWA, K. C. K. Probióticos: uso de probióticos na alimentação de frangos de corte. Revista Biotecnologia Ciência e Desenvolvimento, Minas Gerais, n.8, ano II, p. 40-43, maio/jun 1999 
FAYER, R. Epidemiology of protozoan infections: the coccidia. Veterinary Parasitology, v.6, n.1-3, p.75-103, 1980.

FILHO, L. C. D.; MENDES, C. M. I. Viabilidade Técnica e Econômica na Criação alternativa de frangos. In: CONGRESSO APINCO DE CIÊNCIA E TECNOLOGIA AVÍCOLA. 20., Campinas, 2001. Anais...Campinas: Fundação APINCO de Ciência e Tecnologia Avícola, 2001. p. 255-266

FINGER, P. F. et al. Ganho de peso inicial de matrizes de frangos de corte coloniais com a utilização de um probiótico. CONGRESSO DE INICIAÇÃO CIENTÍFICA 17.; Encontro de Pós-Graduação 10., 2008.

FLEMMING, J. S. Utilização de leveduras, probióticos e mananoligossacarídeos (MOS) na alimentação de frangos de corte. 2005. 109 f. Tese (Doutorado em Tecnologia de Alimentos) - Universidade Federal do Paraná, Paraná, 2005.

FOOD AND AGRICULTURE ORGANIZATION OF THE UNITED NATIONS (FAO). Health and Nutritional Properties of Probiotics in Food including Powder Milk with Live Lactic Acid Bacteria. 2001. Disponível em:

http://www.who.int/foodsafety/publications/fs_management/en/probiotics.pdf, acesso em: 25 de fevereiro de 2010 as 15:26.

FORTES, E. Parasitologia Veterinária. 3ª ed. São Paulo: Ícone Editora Ltda, 1997. $686 \mathrm{p}$.

FREEMAN, B.M. Carbohydrate stores in chickens infected with Eimeria tenella. Parasitology, v. 61, n. 1, p.245-251, 1970

FREITAS, F. L. C. et al. Aspectos clínicos e patológicos em frangos de corte (Gallus gallus domesticus) infectados experimentalmente com oocistos esporlados de Eimeria acervulina Tyzzer, 1929. Revista Brasileira de Parasitologia Veterinária, v.17, n.1, p.16-20, 2008.

FULLER, R. Probiotics in man and animals. Journal of Applied Bacteriology, v.66, n.5, p.365-378, 1989.

FURLAN, R.L.; MACARI, M.; LUQUETTI, B. C. Como avaliar os efeitos do uso de prebioticos, probioticos e flora de exclusão competitiva. In: SIMPÓSIO TÉCNICO DE INCUBAÇÃO, MATRIZES DE CORTE E NUTRIÇÃO. Balneário Camboriú, SC. 2004.

GHADBAN, G. S. Probiotics in broilers production - a review. Archive Geflugelk, v.66, n.2, p.49-58, 2002.

GARLICH, J.D. Microbiologia do tracto intestinal aviar. In: CONGRESSO LATINOAMERICANO DE AVICULTURA. 16., 1999, Lima. Anais... Lima, p. 110-120, 1999. 
GEDEK, B. Probiotics in Animal Feeding. Effects performance and animal health. Feed Management, v.3, p.21-24, 1986.

GIBSON, G. R.; ROBERFORID, M. B. Dietary modulation of the human colonic microbiota, introducing the connect of prebiotics. Journal of Nutrition, v.125, p.14011412, 1995.

GIL DE LOS SANTOS; GIL-TURNES. Probióticos em avicultura. Ciência Rural, v.35, n.3, p.741-747. 2005.

JEFFERS, T. K . Anticoccidial drug resistance: a review with emphasis on the polyether ionophores. In Coccidia and Intestinal Coccidiomorphs: Vth International Coccidiosis Conference, 1989. Tours, France, ed. P. Yvor'e, p. 295-308.

JIN, L. Z.; HO, Y. W. et al. Probiotics in poultry: modes of action World Poultry Sicence Jounal, v.53, p.351-368, 1997.

JIN, L. Z.; HO, Y. W.; ABDULLAH, N.; JALALUDIN, S. Growth performance, intestinal microbial populations, and serum cholesterol of broilers fed diets containing Lactobacillus culture. Poultry Sci. v. 77, p. 1259-1265, 1998.

JOUYBARI, M. G.; Pour, V. R.; Nagharchi, M. M. Z.; Taghizadeh, M. R.; Dehpanah, N. The effect of novel probiotic on blood parameters and performance in broiler chickens. Journal of Cell and Animal Biology, v.3, n.8, p.141-144, Aug. 2009

KALAVATHY, R. et al. Effects of Lactobacillus cultures on Growth performance, abdominal fat deposition, serum lipids and weight of organs of broiler chickens. British Poultry Science, v.44, n.1, p.139-144, 2003.

KANASHIRO, A.M.I., BOTTINO, J.A., FERREIRA, F. CASTRO, A.G.M., FERREIRA, A.J.P., Influencia da administração continua de probiótico a frangos de corte sobre atividades enzimáticas séricas e concentração de colesterol sérico. Arq. Inst. Biol. São Paulo, V. 68, n.2, P. 11-17. 2001.

KAUR, I. P. et al. probiotics: potencial pharmaceutical applications. European Journal of Pharmaceutical Sciences, v.15, p.1-9, 2002.

KAWAZOE, U. Biologia. In: SIMPÓSIO INTERNACIONAL SOBRE COCCIDIOSE. Fundação APINCO de Ciência e Tecnologia Avícolas,1993. P. 1-6.

KAWAZOE, U. Biologia. In: SIMPÓSIO INTERNACIONAL SOBRE COCCIDIOSE, 1994. Santos, SP, FACTA, Anais... cap. 1. p.1-6.

KAWAZOE, U. Coccidiose. In: BERCHIERI, JR., A.; MACARI, M. Doenças das Aves. Campinas: FACTA, 2000. p. 391- 405.

KOS, B. et al. Adhesion and aggregation ability of probiótica strain Lactobacillus acidophilus M92. Journal of applied Microbiology, v. 94, p. 981-987, 2003. 
LAN. P. T. N. et al. impact of two probiotic Lactobacillus strains feeding on fecal lactobacilli and weight gains in chicken. Journal of General and Applied Miceobiology, v.49, n.1, p.29-36, 2003

LEVINE, N. D. The protozoan phylum Apicomplexa. Boca Raton, FL, USA: CRC Press, 1998. V. 1.

LIMA, J. D. Coccidiose dos ruminantes domésticos. Revista Brasileira de ParasitologiaVeterinária, v.13, suplemento 1, 2004

LODDI, M. M. Probióticos, prebióticos e acidificantes orgânicos em dietas para frangos de corte. 2003. 52f. Tese (Doutorado em Zootecnia) - Faculdade de Ciências Agrárias e Veterinárias, Universidade Estadual Paulista "Julio de Mesquita Filho", Jaboticabal, 2003.

LONG, P.L.; JOYNER, L.P.; MILLARD, B.J.; NORTON, C.C. A guide to laboratory techniques used in the study and diagnosis of avian coccidiosis. Folia Vet. Latina, v. 6, p. $201-217,1976$.

LONG, P. L., JOYNER, L. P. Problems in the identification of species of Eimeria. J. Protozool., v. 31, p. 535 - 541, 1984.

LORENÇON, L.; NUNES, R. V.; POZZA, P. C.; POZZA, M. S. S.; APPELT, M. D.; SILVA, W. T. M. Utilização de promotores de crescimento para frangos de corte em rações fareladas e peletizadas. Acta Scientiarum. Animal Science, v. 29, n. 2, p. 151158, 2007.

LUCHESE, F. C et al. Prevalência de espécies de Eimeria em frangos de criação industrial e alternativa. Braz. J. vet. Res. anim. Sci., v. 44, n. 2, p. 81-86, 2007.

MAIORKA, A.; SANTIN, E.; SUGETA, S.M.; ALMEIDA, J.G.; MACARI, M. Utilization of prebiotics, probiotics or symbiotics in broiler chicken diets. Brazilian Journal of Poultry Science, v. 3, n. 1, p. 75-82, 2001.

MARTINS, S. S. Avicultura de corte: situações e perspectivas em maio de 2005. Informações Econômicas, v.35, n.7, p. 57-59, 2005.

MCDOUGALD, L.; REID, W. Coccidiosis. In: CALNEK, B.; BARNES, H.; BEARD, C.; MCDOUGALD, L.; SAIF, Y. Disease of poultry. $10^{\text {th }}$ ed. Iowa State University Press 1997, p. 865-83.

MENTEN, J. F. M.; LODDI, M. M. Probióticos, prebióticos e aditivos fitogênicos na nutrição de aves. In: SIMPÓSIO SOBRE NUTRIÇÃO DE AVES E SUÍNOS, Campinas, 2003. Anais... Campinas: Colégio Brasileiro de Nutrição Animal CBNA, 2003. p. 107138.

MILTENBURG, G. Promotores e aditivos de crescimento em avicultura. In: CONFERENCIA APINCO DE CIÊNCIAS E TECNOLOGIA AVICOLAS, 2000, Campinas. Anais... Campinas: FACTA, p.204-215, 2000. 
MOREHOUSE, N.F.; MCGUIRE, W.C. The pathogenicity of Eimeria acervulina. Poultry Science. v. 37, n. 1, p.665-672, 1958.

MORENO, J. E. G. et al. Adición de dos tipos de probióticoen El água de bebida de pollo de engorde y su efecto en el comportamiento produtivo, metabólico, anatomopatológico e inmunologico. Expedición Científica y Cultura, v.8, 2002. Acessado em 17 de out de 2003. Disponível em:

<http:// www.unad.edu.com/revistaunad/revista08/cienciasagrariasadicionde.htm>. In: SANTOS, R. G. Probióticos em avicultura. Ciência Rural, Santa Maria, V.35, n.3, p.741747, mai-jun, 2005.

MORGULIS, M. S. Imunologia aplicada. In: MACARI, M.; FURLAN, R. L.; GONZALES, E. eds. Fisiologia aviária aplicada a frango de corte. Jaboticabal: FUNEP/UNESP, 2002, 375 p.

MUIR, W. I.; BRYDEN, W. L.; HUSBAND, A. J. Immunity, vaccination and the avian intestinal tract. Developmental and Comparative Immunology. n.24, p.325 - 342, nov. 2000.

NEPOMUCENO, E. S.; ANDREATTI, R. L. F. Probióticos e prebióticos na avicultura. In: II SIMPÓSIO DE SANIDADE AVÍCOLA, 2000, Santa Maria, RS. Anais... Concórdia, SC: EMBRAPA SUÍNOS E AVES, 2000. v.1, p 45-55.

NURMI, E.; RANTALA, M. New aspects of Salmonella infection in broiler production. Nature, v.241, p.210-211, 1973.

OLIVEIRA-SEQUEIRA, Teresa Cristina Goulart de; RIBEIRO, Cláudia Mello; GOMES, Maria Isabel Franchi Vasconcelos. Potencial bioterapêutico dos probióticos nas parasitoses intestinais. Cienc. Rural, Santa Maria, v. 38, n. 9, Dec. 2008.

OKUDA, T. O frango brasileiro conquista o mundo. Anuário de avicultura industrial, São Paulo, v. 87, n. 1040, p. 32-43, 1996.

OTUTUMI, Luciana Kazue et al . Diferentes vias de administração de probiótico sobre o desempenho, o rendimento de carcaça e a população microbiana do intestino delgado de codornas de corte. Revista Brasileira de Zootecnia, Viçosa, v. 39, n. 1, Jan. 2010.

PEDROSO, A.A.; MENTEN, J.F.M.; RACANICCI, A.M.C.; LONGO, F.A.; SORBARA, J.O.; GAIOTTO, J.B. Performance and organ morphology of broilers fed microbial or antimicrobial additives and raised in batteries or floor pens. Brazilian Journal of Poultry Science, Campinas, v. 5, n. 2, p. 111-117, 2003.

PELICANO, E.R.L.; SOUZA, P.A.; SOUZA, H.B.A. et al. Utilização de probióticos e/ou prebióticos como promotores de crescimento em rações iniciais de frangos de corte. Revista Brasileira de Ciência Avícola, Suplemento 6, p.17, 2004.

PERDIGON, G.; ALVAREZ, S.; RACHID, M.; AGUERO, G.; GOBBATO, N. Immune system stimulation by probiotics. J. Dairy Sci., v. 78, p. 1597-1606, 1995. 
PEREIRA, C. A. S.. Avaliação do efeito de microrganismos probióticos sobre Eimeria spp em Rattus norvegicus. 2007. 77f. Tese (Doutorado - Programa de Pós-Graduação em Biotecnologia Industrial. Área de Concentração: Microbiologia Aplicada) - Escola de Engenharia de Lorena da Universidade de São Paulo, Lorena, 2007.

PETRI, R. Uso de exclusão competitiva na avicultura no Brasil. In: SIMPÓSIO DE SANIDADE AVÍCOLA 2., 2000, Santa Maria. Anais...

ROSSI, A. A.; PADILHA, M. T. S; SANTOS, I. I.; PADILHA, J. C. F. Uso de probiótico na prevenção de salmoneloses em frangos de corte. Ciênc. agrotec., Lavras, v. 31, n. 4, 2007 .

RUFF, M.D.; WILKINS, G.C. Total intestinal absorption of glucose and L-methionine in broilers infected with Eimeria acervulina, E. mivati, E. maxima or E. brunette. Parasitology, v.80, p.555-569, 1980

SALMINEN, S. et al. Clinical application of probiotic bacteria. Internacional Dairy Journal., v.8, p.563-572, 1998.

SALMINEN, S. et al. Probiotics: how should they be defined? Trends in Food Science \& Tecnolog, v.10, p.107-110, 1999.

SANTOS, I. I.; Promotores de crescimento na Alimentação de Frangos de Corte: Desempenho Zootecnico e Análise de Resíduos (Antibióticos) na Cama de Aviário. 2002. 80f. Dissertação (mestrado em Agroecossistemas) - Centro de Ciências, Universidade de Santa Catarina, Florianópolis, 2002.

SANTOS, I.I.; POLI, A.; PADILHA, M.T.S. Desempenho zootécnico e rendimento de carcaça de frangos suplementados com diferentes probióticos e antimicrobianos. Acta Scientarium Animal Sciences, Campinas, v. 26, n. 1, p. 29-33, 2004.

SANTOS, R. G. Probióticos em avicultura. Ciência Rural, Santa Maria, v.35, n.3, p.741747, mai-jun, 2005.

SAVAGE, D. C. Microbial ecology of the gastrointestinal tract. Annual Veterinary Microbiology, New York, n.31, p. 107-133, 1977.

SCHNITZLER, B. E. \& SHIRLEY, M. W. Immunological aspects of infections with Eimeria maxima: a short review. Avian Pathol., v. 28, p. 537 - 543, 1999.

SCHREZENMER, J.; DE VRESE, M. Probiotics, prebiotics and symbiotics-approaching a definition. American Journal of Clinical Nutricion, v.73, p.361S-364S, 2001.

SHIRLEY, M. W. Vacinas vivas: atenuadas e virulentas. In: SIMPÓSIO INTERNACILNAL SOBRE COCCIDIOSE AVIÁRIA.1989. Santos, SP, p. 109-124.

SIMON, O.; JADAMUS, A.; VAHJEN, E. Probiotic feed additives - effectiveness and expected modes of action. J. Anim. Feed Sci. v. 10, p. 51-67, 2001. 
SILVA, E. N., Probióticos e Prebióticos na Alimentação de aves. In: Conferência APINCO'2000 de ciência e tecnologia, 2000. p. 242.

SILVA, C. R.. Uso de probiótico em ração de frangos de corte: desempenho, digestibilidade e energia metabolizável. 77f. Dissertação (mestrado em Zootecnia) Universidade Federal de Viçosa, Viçosa, 2008.

SOULSBY, E. J. L. Parasitologia y enfermedades parasitárias de los animales domésticos. $7^{\circ}$ Ed., México: Nueva Editorial Interamericana, 1987. 823p.

TEIXEIRA, M. Anátomo-Clínica e Biologia em Frangos de Corte Experimentalmente Infectados com Eimeria acervulina e Suplementados com Betaína. Tese (Doutor em Ciências Veterinárias, Área de concentração em Sanidade Animal. UNIVERSIDADE FEDERAL RURAL DO RIO DE JANEIRO INSTITUTO DE VETERINÁRIA, Seropédica, RJ, 2007.

TEIXEIRA, R. S. Avaliação do efeito de micro-organismos probióticos sobre Haemonchus contortus em ovinos. Dissertação (Mestrado em Biotecnologia Industrial) - Escola de Engenharia de Lorena USP, Lorena-SP, 2011.

TIERNEY, J. et al. In vitro inhibition of Eimeria tenella invasion bu indigenous chicken Lactobacillus species. Veterinary Parasitology, v.122, p.171-182, 2004.

UBABEF. União brasileira de aviculture: relatório anual - produção de carne. Disponível em: <http://www.abef.com.br/ubabef/publicacoes_relatoriosanuais.php $>$. Acesso em: 20/08/2011.

ZULKIFLI, I.; ABDULLAH, N.; MOHD AZRIN, N.; HO, Y. W. Growth performance and immune response of two commercial broiler strains fed diets containing Lactobacillus cultures and oxytetracycline under heat stress conditions. British Poultry Science, v. 41, p. 593-597, 2000. 
APÊNDICES 


\section{APÊNDICE A}

Oocistos por grama de fezes em frangos de corte infectados com Eimeria acervulina e submetidos ao tratamento com preparação probiótica.

\begin{tabular}{ccccccccc}
\hline Tratamentos & \multicolumn{7}{c}{ Dias de coleta de material } \\
\hline & $4^{\text {o }}$ & $5^{\circ}$ & $6^{\circ}$ & $7^{\circ}$ & $8^{\circ}$ & $9^{\circ}$ & $10^{\circ}$ & $11^{\circ}$ \\
\hline G3 & 0 & 1846000 & 1202000 & 704000 & 448000 & 29600 & 800 & 0 \\
G4 & 400 & 1326000 & 802000 & 374000 & 68300 & 4400 & 300 & 0 \\
G5 & 200 & 1556000 & 1244000 & 600000 & 216000 & 11200 & 800 & 0 \\
G6 & 0 & 706000 & 1077000 & 446000 & 354000 & 23800 & 2600 & 0 \\
\hline
\end{tabular}




\section{APÊNDICE B}

Parâmetros bioquímicos de proteínas totais, albumina e glicose em frangos de corte infectados experimentalmente com oocistos de Eimeria acervulina e submetidos a diferentes tratamentos.

\begin{tabular}{|c|c|c|c|c|c|c|}
\hline \multirow[t]{2}{*}{ Grupos } & \multicolumn{5}{|c|}{ Tratamentos } & \multirow[b]{2}{*}{28} \\
\hline & 0 & 4 & 7 & 14 & 21 & \\
\hline \multicolumn{7}{|c|}{ Proteínas totais } \\
\hline G1 & 31,4 & 31,4 & 24,6 & 34,2 & 27,4 & 32,3 \\
\hline G1' & 22,5 & 25,6 & 26,4 & 29,7 & 33,6 & 29,3 \\
\hline G2 & 23,8 & 25,5 & 28,3 & 35,3 & 27,6 & 32,9 \\
\hline G2' & 28,7 & 26,8 & 20 & 30 & 41,4 & 28,3 \\
\hline G3 & 24,6 & 23,4 & 26,6 & 35,3 & 29,1 & 29,5 \\
\hline G3' & 23,8 & 29,3 & 17,6 & 30,2 & 28,7 & 29,3 \\
\hline G4 & 25,9 & 28,7 & 25,1 & 38,3 & 30 & 30 \\
\hline G4' & 26,1 & 28,7 & 21,2 & 32,1 & 33,1 & 34,7 \\
\hline G5 & 29,7 & 26,4 & 25,1 & 28,3 & 28,7 & 31 \\
\hline G5 & 27,6 & 24 & 21,2 & 30,2 & 28,9 & 28 \\
\hline G6 & 26,3 & 20,4 & 23,2 & 31,9 & 28,9 & 29,5 \\
\hline G6' & 29,5 & 25,9 & 20,7 & 30,6 & 28 & 29,8 \\
\hline \multicolumn{7}{|c|}{ Albumina } \\
\hline G1 & 1,77 & 1,83 & 1,73 & 1,84 & 1,54 & 1,78 \\
\hline G1' & 1,43 & 1,65 & 1,82 & 1,8 & 1,88 & 1,77 \\
\hline $\mathrm{G} 2$ & 1,47 & 1,6 & 1,69 & 1,92 & 1,67 & 1,92 \\
\hline G2' & 1,74 & 1,75 & 1,48 & 1,71 & 1,87 & 1,71 \\
\hline G3 & 1,66 & 1,64 & 1,72 & 2,05 & 1,81 & 1,72 \\
\hline G3' & 1,56 & 1,8 & 1,21 & 1,75 & 1,67 & 1,62 \\
\hline G4 & 1,75 & 1,76 & 1,54 & 2,04 & 1,81 & 1,81 \\
\hline G4' & 1,79 & 1,98 & 1,35 & 1,84 & 1,84 & 1,9 \\
\hline G5 & 1,83 & 1,79 & 1,52 & 1,81 & 1,77 & 1,66 \\
\hline G5 & 1,78 & 1,69 & 1,61 & 1,75 & 1,81 & 1,58 \\
\hline G6 & 1,77 & 1,53 & 1,53 & 1,84 & 1,77 & 1,68 \\
\hline G6' & 1,88 & 1,78 & 1,38 & 1,81 & 1,74 & 1,55 \\
\hline \multicolumn{7}{|c|}{ Glicose } \\
\hline G1 & 313,6 & 253,4 & 262,9 & 291,1 & 262,9 & 275,4 \\
\hline G1' & 373,3 & 277,8 & 281,6 & 249,1 & 263,4 & 244,6 \\
\hline G2 & 225,2 & 266,8 & 273,5 & 248,6 & 269,6 & 248 \\
\hline G2' & 270,6 & 265,3 & 273 & 294,5 & 224,3 & 237 \\
\hline G3 & 327,9 & 295,9 & 262,5 & 258,6 & 272 & 222,2 \\
\hline G3' & 286,8 & 243,8 & 322,2 & 253,4 & 284,9 & 247,2 \\
\hline G4 & 260,1 & 280,6 & 285,4 & 252,4 & 293 & 292,6 \\
\hline G4' & 266,8 & 272,5 & 304 & 231,4 & 279,2 & 257 \\
\hline G5 & 296,4 & 260,1 & 273,9 & 258,6 & 258,6 & 277,6 \\
\hline G5 & 279,2 & 313,6 & 259,6 & 198,5 & 244,3 & 256 \\
\hline G6 & 276,3 & 290,7 & 285,4 & 223,8 & 265,8 & 242 \\
\hline G6' & 270,1 & 281,6 & 322,2 & 261 & 271,5 & 254,7 \\
\hline
\end{tabular}




\section{APÊNDICE C}

Parâmetros bioquímicos de colesterol total, HDL e triglicerídeos em frangos de corte infectados experimentalmente com oocistos de Eimeria acervulina e submetidos a diferentes tratamentos.

\begin{tabular}{|c|c|c|c|c|c|c|}
\hline \multirow[t]{2}{*}{ Grupos } & \multicolumn{5}{|c|}{ Tratamentos } & \multirow[b]{2}{*}{28} \\
\hline & 0 & 4 & 7 & 14 & 21 & \\
\hline \multicolumn{7}{|c|}{ Colesterol total } \\
\hline G1 & 128,5 & 95,9 & 111,8 & 109,7 & 108,9 & 93,7 \\
\hline G1' & 77,8 & 95,9 & 64,1 & 101,7 & 121,3 & 88,7 \\
\hline $\mathrm{G} 2$ & 141,5 & 0 & 116,9 & 121,3 & 111,1 & 115,5 \\
\hline G2' & 132,1 & 0 & 85,1 & 122 & 89,4 & 79,3 \\
\hline G3 & 121,3 & 107,5 & 112,6 & 124,1 & 125,6 & 101 \\
\hline G3' & 141,5 & 108,2 & 74,9 & 115,5 & 119,1 & 98,1 \\
\hline G4 & 125,6 & 119,1 & 99,5 & 107,5 & 154,6 & 103 \\
\hline G4' & 114,7 & 127,8 & 93,7 & 116,9 & 122,7 & 101 \\
\hline G5 & 124,1 & 109,7 & 86,5 & 121,3 & 105,3 & 106,8 \\
\hline G5 & 137,2 & 101 & 94,05 & 114,7 & 102,4 & 101,7 \\
\hline G6 & 140,1 & 90,1 & 93 & 124,1 & 111,1 & 81,4 \\
\hline G6’ & 151,7 & 101 & 87,2 & 105,3 & 101,7 & 105,3 \\
\hline \multicolumn{7}{|c|}{ HDL } \\
\hline G1 & 84,8 & 132,4 & 95,4 & 55,6 & 58,3 & 67,5 \\
\hline G1' & 61,6 & 133,8 & 64,9 & 58,9 & 50,3 & 54,3 \\
\hline $\mathrm{G} 2$ & 104 & 123,8 & 55 & 57,6 & 62,9 & 75,5 \\
\hline G2' & 101,3 & 123,8 & 60,9 & 64,2 & 68,9 & 56,9 \\
\hline G3 & 84,1 & 86,1 & 62,2 & 60,3 & 63,6 & 65,6 \\
\hline G3' & 93,4 & 96,7 & 50,3 & 59,6 & 58,9 & 51,6 \\
\hline G4 & 77,5 & 101,3 & 49 & 60,9 & 79,5 & 64,2 \\
\hline G4' & 62,2 & 87,4 & 50,3 & 58,9 & 68,9 & 54,3 \\
\hline G5 & 69,5 & 77,5 & 45,7 & 60,3 & 47 & 53,6 \\
\hline G5 & 81,4 & 71,5 & 67,5 & 51,6 & 54,3 & 45,7 \\
\hline G6 & 88,1 & 79,5 & 49 & 61,6 & 56,3 & 41,7 \\
\hline G6’ & 88,1 & 88,1 & 43,7 & 53,6 & 49 & 48,3 \\
\hline \multicolumn{7}{|c|}{ Triglicerídeos } \\
\hline G1 & 123,5 & 0 & 83,3 & 136,9 & 26,3 & 82,1 \\
\hline G1' & 74,3 & 0 & 53,1 & 73,2 & 58,7 & 34,1 \\
\hline $\mathrm{G} 2$ & 94,4 & 55,3 & 69,9 & 114,6 & 67,6 & 68,7 \\
\hline G2' & 78,8 & 55,3 & 43 & 97,8 & 28,5 & 61 \\
\hline G3 & 91,1 & 71 & 82,1 & 107,7 & 81 & 84,4 \\
\hline G3' & 120,1 & 49,7 & 45,3 & 77,7 & 72,1 & 67,6 \\
\hline G4 & 69,9 & 77,7 & 67,6 & 85,5 & 67,6 & 96,7 \\
\hline G4' & 67,6 & 88,9 & 36,3 & 95,6 & 87,7 & 101,1 \\
\hline G5 & 122,4 & 69,9 & 116,8 & 98,9 & 43 & 85,5 \\
\hline G5 & 132,4 & 74,3 & 83,3 & 84,4 & 50,9 & 91,1 \\
\hline G6 & 92,2 & 34,1 & 59,8 & 101,1 & 44,1 & 90 \\
\hline G6' & 112,3 & 33 & 68,7 & 120,1 & 54,2 & 74,3 \\
\hline
\end{tabular}




\section{APÊNDICE D}

Parâmetros significativos da análise estatística (test $\mathrm{T}$ ) dos testes bioquímicos em frangos de corte infectados com oocistos de Eimeria acervulina e submetidos a diferentes tratamentos.

\begin{tabular}{|c|c|c|c|c|c|}
\hline Média & Média & Média & T-calculado & Grau de liberdade & $\mathbf{P}$ \\
\hline \multicolumn{6}{|c|}{ Colesterol Total } \\
\hline C4G1 vs. C4G2 & 95,90 & 0,00 & - & 2 & - \\
\hline C4G1 vs. C4G3 & 95,90 & 107,85 & $-34,14$ & 2 & 0,001 \\
\hline C4G1 vs. C4G4 & 95,90 & 123,45 & $-6,33$ & 2 & 0,024 \\
\hline C4G1 vs. C4G5 & 95,90 & 105,35 & $-2,17$ & 2 & 0,162 \\
\hline C4G1 vs. C4G6 & 95,90 & 95,55 & 0,06 & 2 & 0,955 \\
\hline \multicolumn{6}{|c|}{ HDL } \\
\hline H4G2 vs. H4G1 & 123,80 & 133,10 & $-13,29$ & 2 & 0,006 \\
\hline H4G2 vs. H4G3 & 123,80 & 91,40 & 6,11 & 2 & 0,026 \\
\hline H4G2 vs. H4G4 & 123,80 & 94,35 & 4,24 & 2 & 0,051 \\
\hline H4G2 vs. H4G5 & 123,80 & 74,50 & 16,43 & 2 & 0,004 \\
\hline H4G2 vs. H4G6 & 123,80 & 83,80 & 9,30 & 2 & 0,011 \\
\hline \multicolumn{6}{|c|}{ Triglicerídeos } \\
\hline T4G2 vs. T4G1 & 55,30 & 0,00 & - & 2 & - \\
\hline T4G2 vs. T4G3 & 55,30 & 60,35 & $-0,47$ & 2 & 0,682 \\
\hline T4G2 vs. T4G4 & 55,30 & 83,30 & $-5,00$ & 2 & 0,038 \\
\hline T4G2 vs. T4G5 & 55,30 & 72,10 & $-7,64$ & 2 & 0,017 \\
\hline T4G2 vs. T4G6 & 55,30 & 33,55 & 39,55 & 2 & 0,001 \\
\hline
\end{tabular}

- Resultados com significância estatística em vermelho. 


\section{APÊNDICE E}

Peso vivo e peso morto, com vísceras comestíveis, em frangos de corte, linhagem Cobb, infectados experimentalmente com oocistos esporulados de Eimeria acervulina e submetidos a diferentes tratamentos.

\begin{tabular}{|c|c|c|c|c|c|c|}
\hline \multirow[t]{2}{*}{ Gaiolas } & \multicolumn{5}{|c|}{ Tratamentos } & \multirow[b]{2}{*}{28} \\
\hline & 0 & 4 & 7 & 14 & 21 & \\
\hline \multicolumn{7}{|c|}{ Média do peso vivo (Kg) } \\
\hline G1 & 0,430 & 0,535 & 0,760 & 1,455 & 2,050 & 3,040 \\
\hline G1' & 0,420 & 0,605 & 0,825 & 1,580 & 2,065 & 2,925 \\
\hline $\mathrm{G} 2$ & 0,460 & 0,630 & 0,805 & 1,385 & 2,255 & 3,130 \\
\hline G2' & 0,415 & 0,620 & 0,780 & 1,435 & 2,240 & 3,425 \\
\hline G3 & 0,420 & 0,650 & 0,770 & 1,280 & 2,050 & 2,975 \\
\hline G3' & 0,420 & 0,545 & 0,520 & 1,110 & 2,125 & 2,700 \\
\hline G4 & 0,415 & 0,600 & 0,610 & 1,365 & 2,050 & 3,125 \\
\hline G4' & 0,430 & 0,665 & 0,795 & 1,400 & 2,200 & 2,895 \\
\hline G5 & 0,415 & 0,650 & 0,670 & 1,275 & 1,840 & 2,845 \\
\hline G5 & 0,415 & 0,655 & 0,600 & 1,220 & 1,840 & 2,695 \\
\hline G6 & 0,420 & 0,620 & 0,645 & 1,165 & 2,105 & 2,910 \\
\hline G6' & 0,420 & 0,580 & 0,730 & 1,275 & 2,040 & 2,795 \\
\hline \multicolumn{7}{|c|}{ Média do peso carcaça com vísceras comestíveis (g) } \\
\hline G1 & 0,330 & 0,395 & 0,575 & 1,135 & 1,680 & 2,575 \\
\hline G1' & 0,315 & 0,440 & 0,640 & 1,250 & 1,640 & 2,455 \\
\hline $\mathrm{G} 2$ & 0,355 & 0,475 & 0,615 & 1,095 & 1,870 & 2,590 \\
\hline $\mathrm{G} 2$ ' & 0,320 & 0,455 & 0,605 & 1,140 & 1,860 & 2,840 \\
\hline G3 & 0,315 & 0,480 & 0,550 & 0,975 & 1,645 & 2,445 \\
\hline G3' & 0,315 & 0,390 & 0,455 & 0,865 & 1,700 & 2,220 \\
\hline G4 & 0,335 & 0,520 & 0,460 & 1,050 & 1,665 & 2,580 \\
\hline G4' & 0,310 & 0,440 & 0,580 & 1,065 & 1,790 & 2,385 \\
\hline G5 & 0,300 & 0,500 & 0,500 & 0,975 & 1,485 & 2,275 \\
\hline G5, & 0,320 & 0,495 & 0,445 & 0,935 & 1,480 & 2,270 \\
\hline G6 & 0,315 & 0,465 & 0,475 & 0,875 & 1,720 & 2,445 \\
\hline G6’ & 0,320 & 0,435 & 0,525 & 0,985 & 1,600 & 2,310 \\
\hline
\end{tabular}




\section{APÊNDICE F}

Análise estatística, método test $\mathrm{T}$, do peso vivo de frangos de corte, linhagem Cobb, infectados experimentalmente com oocistos esporulados de Eimeria acervulina e submetidos a diferentes tratamentos com preparação probiótica de Lactobacillus spp.

\begin{tabular}{|c|c|c|c|c|c|}
\hline Tratamento & Média & Média & T-calculado & Grau de liberdade & $\mathbf{P}$ \\
\hline \multicolumn{6}{|c|}{0 dpi } \\
\hline Pv0G1 vs. Pv0G2 & 0,425 & 0,438 & $-0,54$ & 2 & 0,642 \\
\hline Pv0G1 vs. Pv0G3 & 0,425 & 0,420 & 1,00 & 2 & 0,423 \\
\hline Pv0G1 vs. Pv0G4 & 0,425 & 0,422 & 0,28 & 2 & 0,808 \\
\hline Pv0G1 vs. Pv0G5 & 0,425 & 0,415 & 2,00 & 2 & 0,184 \\
\hline Pv0G1 vs. Pv0G6 & 0,425 & 0,420 & 1,00 & 2 & 0,423 \\
\hline \multicolumn{6}{|c|}{$4 \mathrm{dpi}$} \\
\hline Pv4G1 vs. Pv4G2 & 0,570 & 0,625 & $-1,56$ & 2 & 0,260 \\
\hline Pv4G1 vs. Pv4G3 & 0,570 & 0,598 & $-0,44$ & 2 & 0,705 \\
\hline Pv4G1 vs. Pv4G4 & 0,570 & 0,633 & $-1,31$ & 2 & 0,321 \\
\hline Pv4G1 vs. Pv4G5 & 0,570 & 0,653 & $-2,35$ & 2 & 0,143 \\
\hline Pv4G1 vs. Pv4G6 & 0,570 & 0,600 & $-0,74$ & 2 & 0,534 \\
\hline \multicolumn{6}{|c|}{$7 \mathrm{dpi}$} \\
\hline Pv7G1 vs. Pv7G2 & 0,792 & 0,792 & 0,00 & 2 & 1,000 \\
\hline Pv7G1 vs. Pv7G3 & 0,792 & 0,645 & 1,14 & 2 & 0,372 \\
\hline Pv7G1 vs. Pv7G4 & 0,792 & 0,703 & 0,92 & 2 & 0,456 \\
\hline Pv7G1 vs. Pv7G5 & 0,792 & 0,635 & 3,30 & 2 & 0,081 \\
\hline Pv7G1 vs. Pv7G6 & 0,792 & 0,688 & 1,96 & 2 & 0,189 \\
\hline \multicolumn{6}{|c|}{$14 \mathrm{dpi}$} \\
\hline Pv14G1 vs. Pv14G2 & 1,518 & 1,410 & 1,60 & 2 & 0,251 \\
\hline Pv14G1 vs. Pv14G3 & 1,518 & 1,195 & 3,06 & 2 & 0,092 \\
\hline Pv14G1 vs. Pv14G4 & 1,518 & 1,382 & 2,08 & 2 & 0,173 \\
\hline Pv14G1 vs. Pv14G5 & 1,518 & 1,248 & 3,95 & 2 & 0,058 \\
\hline Pv14G1 vs. Pv14G6 & 1,518 & 1,220 & 3,57 & 2 & 0,070 \\
\hline \multicolumn{6}{|c|}{$21 \mathrm{dpi}$} \\
\hline Pv21G1 vs. Pv21G2 & 2,058 & 2,218 & $-4,18$ & 2 & 0,053 \\
\hline Pv21G1 vs. Pv21G3 & 2,058 & 2,087 & $-0,78$ & 2 & 0,515 \\
\hline Pv21G1 vs. Pv21G4 & 2,058 & 2,125 & $-0,90$ & 2 & 0,465 \\
\hline Pv21G1 vs. Pv21G5 & 2,058 & 1,975 & 2,30 & 2 & 0,148 \\
\hline Pv21G1 vs. Pv21G6 & 2,058 & 2,072 & $-0,45$ & 2 & 0,697 \\
\hline \multicolumn{6}{|c|}{$28 \mathrm{dpi}$} \\
\hline Pv28G1 vs. Pv28G2 & 2,982 & 3,277 & $-1,86$ & 2 & 0,203 \\
\hline Pv28G1 vs. Pv28G3 & 2,982 & 2,838 & 0,97 & 2 & 0,433 \\
\hline Pv28G1 vs. Pv28G4 & 2,982 & 3,010 & $-0,21$ & 2 & 0,850 \\
\hline Pv28G1 vs. Pv28G5 & 2,982 & 2,770 & 2,25 & 2 & 0,154 \\
\hline Pv28G1 vs. Pv28G6 & 2,982 & 2,853 & 1,60 & 2 & 0,251 \\
\hline
\end{tabular}

- Dpi: Dias pós infecção. 


\section{APÊNDICE G}

Análise estatística (test T) referente ao peso de carcaça com vísceras comestíveis de frangos de corte, linhagem Cobb, infectados experimentalmente com oocistos esporulados de Eimeria acervulina e submetidos a diferentes tratamentos com preparação probiótica de Lactobacillus spp.

\begin{tabular}{|c|c|c|c|c|c|}
\hline Tratamento & Média & Média & T-calculado & Grau de liberdade & $\mathbf{P}$ \\
\hline \multicolumn{6}{|c|}{0 dpi } \\
\hline PM0G1 vs. PM0G2 & 0,323 & 0,337 & $-0,79$ & 2 & 0,513 \\
\hline PM0G1 vs. PM0G3 & 0,323 & 0,315 & 1,00 & 2 & 0,423 \\
\hline PM0G1 vs. PM0G4 & 0,323 & 0,323 & 0,00 & 2 & 1,000 \\
\hline PM0G1 vs. PM0G5 & 0,323 & 0,310 & 1,00 & 2 & 0,423 \\
\hline PM0G1 vs. PM0G6 & 0,323 & 0,318 & 0,63 & 2 & 0,592 \\
\hline \multicolumn{6}{|c|}{4 dpi } \\
\hline PM4G1 vs. PM4G2 & 0,417 & 0,465 & $-1,93$ & 2 & 0,193 \\
\hline PM4G1 vs. PM4G3 & 0,417 & 0,435 & $-0,35$ & 2 & 0,761 \\
\hline PM4G1 vs. PM4G4 & 0,417 & 0,480 & $-1,36$ & 2 & 0,306 \\
\hline PM4G1 vs. PM4G5 & 0,417 & 0,498 & $-3,53$ & 2 & 0,072 \\
\hline PM4G1 vs. PM4G6 & 0,417 & 0,450 & $-1,20$ & 2 & 0,352 \\
\hline \multicolumn{6}{|c|}{7 dpi } \\
\hline PM7G1 vs. PM7G2 & 0,607 & 0,610 & $-0,08$ & 2 & 0,946 \\
\hline PM7G1 vs. PM7G3 & 0,607 & 0,461 & 1,82 & 2 & 0,210 \\
\hline PM7G1 vs. PM7G4 & 0,607 & 0,520 & 1,28 & 2 & 0,328 \\
\hline PM7G1 vs. PM7G5 & 0,607 & 0,473 & 3,17 & 2 & 0,087 \\
\hline PM7G1 vs. PM7G6 & 0,607 & 0,500 & 2,62 & 2 & 0,120 \\
\hline \multicolumn{6}{|c|}{14 dpi } \\
\hline PM14G1 vs. PM14G2 & 1,192 & 1,117 & 1,21 & 2 & 0,348 \\
\hline PM14G1 vs. PM14G3 & 1,192 & 0,920 & 3,42 & 2 & 0,076 \\
\hline PM14G1 vs. PM14G4 & 1,192 & 1,058 & 2,33 & 2 & 0,145 \\
\hline PM14G1 vs. PM14G5 & 1,192 & 0,955 & 3,90 & 2 & 0,060 \\
\hline PM14G1 vs. PM14G6 & 1,192 & 0,930 & 3,30 & 2 & 0,081 \\
\hline \multicolumn{6}{|c|}{$21 \mathrm{dpi}$} \\
\hline PM21G1 vs. PM21G2 & 1,660 & 1,815 & $-2,65$ & 2 & 0,118 \\
\hline PM21G1 vs. PM21G3 & 1,660 & 1,673 & $-0,37$ & 2 & 0,748 \\
\hline PM21G1 vs. PM21G4 & 1,660 & 1,728 & $-1,03$ & 2 & 0,412 \\
\hline PM21G1 vs. PM21G5 & 1,660 & 1,583 & 0,78 & 2 & 0,518 \\
\hline PM21G1 vs. PM21G6 & 1,660 & 1,660 & 0,00 & 2 & 1,000 \\
\hline \multicolumn{6}{|c|}{$28 \mathrm{dpi}$} \\
\hline PM28G1 vs. PM28G2 & 2,515 & 2,715 & $-1,44$ & 2 & 0,286 \\
\hline PM28G1 vs. PM28G3 & 2,515 & 2,332 & 1,43 & 2 & 0,289 \\
\hline PM28G1 vs. PM28G4 & 2,515 & 2,482 & 0,28 & 2 & 0,803 \\
\hline PM28G1 vs. PM28G5 & 2,515 & 2,273 & 4,04 & 2 & 0,056 \\
\hline PM28G1 vs. PM28G6 & 2,515 & 2,377 & 1,52 & 2 & 0,267 \\
\hline
\end{tabular}

- Dpi: Dias pós infecção. 


\section{APÊNDICE H}

Rendimento de carcaça de frangos de corte, linhagem Cobb, infectados experimentalmente com oocistos esporulados de Eimeria acervulina e submetidos a diferentes tratamentos.

\begin{tabular}{ccccccc}
\hline Gaiolas & \multicolumn{7}{c}{ Tratamentos } & & \\
\hline & 0 & 4 & 7 & 14 & 21 & 28 \\
\hline \multicolumn{7}{c}{ Gendimento de carcaça } \\
\hline G1 & $77 \%$ & $74 \%$ & $76 \%$ & $78 \%$ & $82 \%$ & $85 \%$ \\
G2 & $75 \%$ & $73 \%$ & $78 \%$ & $79 \%$ & $79 \%$ & $84 \%$ \\
G2' & $77 \%$ & $75 \%$ & $76 \%$ & $79 \%$ & $83 \%$ & $83 \%$ \\
G3 & $77 \%$ & $73 \%$ & $78 \%$ & $79 \%$ & $83 \%$ & $83 \%$ \\
G3 & $75 \%$ & $74 \%$ & $71 \%$ & $76 \%$ & $80 \%$ & $83 \%$ \\
G4 & $81 \%$ & $72 \%$ & $88 \%$ & $78 \%$ & $80 \%$ & $83 \%$ \\
G4' & $72 \%$ & $66 \%$ & $75 \%$ & $77 \%$ & $81 \%$ & $83 \%$ \\
G5 & $72 \%$ & $77 \%$ & $75 \%$ & $76 \%$ & $81 \%$ & $83 \%$ \\
G5 & $77 \%$ & $76 \%$ & $74 \%$ & $77 \%$ & $81 \%$ & $80 \%$ \\
G6 & $75 \%$ & $75 \%$ & $74 \%$ & $75 \%$ & $82 \%$ & $84 \%$ \\
G6 & $76 \%$ & $75 \%$ & $72 \%$ & $77 \%$ & $78 \%$ & $83 \%$ \\
\hline
\end{tabular}




\section{APÊNDICE I}

Análise estatística (test-T) dos valores de rendimento de carcaça de frangos de corte, linhagem Cobb, aos 21 e 42 dias de vida, infectados experimentalmente com oocistos esporulados de Eimeria acervulina e submetidos a diferentes tratamentos.

\begin{tabular}{|c|c|c|c|c|c|}
\hline Tratamentos & Média & Média & T-calculado & Grau de liberdade & $\mathbf{P}$ \\
\hline \multicolumn{6}{|c|}{7 dpi* } \\
\hline Rc7G1 vs. Rc 7G2 & 0,77 & 0,77 & $-0,32$ & 2 & 0,776 \\
\hline Re $7 G 1$ vs. Rc 7G3 & 0,77 & 0,8 & $-0,35$ & 2 & 0,759 \\
\hline Re $7 G 1$ vs. Rc 7G4 & 0,77 & 0,74 & 1,56 & 2 & 0,258 \\
\hline Rc 7G1 vs. Rc 7G5 & 0,77 & 0,74 & 2,25 & 2 & 0,153 \\
\hline Re 7G1 vs. Re 7G6 & 0,77 & 0,73 & 2,97 & 2 & 0,097 \\
\hline \multicolumn{6}{|c|}{$28 \mathrm{dpi}^{*} *$} \\
\hline Re 28G1 vs. Rc $28 G 2$ & 0,84 & 0,83 & 3,75 & 2 & 0,064 \\
\hline Rc $28 G 1$ vs. Rc $28 G 3$ & 0,84 & 0,83 & 3,52 & 2 & 0,072 \\
\hline Rc 28G1 vs. Rc 28G4 & 0,84 & 0,83 & 3,48 & 2 & 0,073 \\
\hline Re 28G1 vs. Re $28 G 5$ & 0,84 & 0,82 & 1,02 & 2 & 0,413 \\
\hline Re $28 G 1$ vs. Re $28 G 6$ & 0,84 & 0,83 & 1,25 & 2 & 0,338 \\
\hline
\end{tabular}

- dpi: Dias pós infecção.

* - Animais com 21 dias de vida

** - Animais com 42 dias de vida 


\section{APÊNDICE J}

Desempenho zootécnico de frangos de corte, linhagem Cobb, com 42 dias de vida, infectados experimentalmente com oocistos esporulados de Eimeria acervulina e submetidos a diferentes tratamentos com preparação probiótica de Lactobacillus spp..

\begin{tabular}{|c|c|c|c|c|c|c|}
\hline \multirow[t]{2}{*}{ Gaiolas } & \multicolumn{5}{|c|}{ Tratamentos } & \multirow[b]{2}{*}{ G6 } \\
\hline & G1 & G2 & G3 & G4 & G5 & \\
\hline \multicolumn{7}{|c|}{ Consumo de ração (g) } \\
\hline 1 & 4110,3 & 4111,3 & 3917,0 & 3858,5 & 3733,7 & 3752,1 \\
\hline 2 & 4081,7 & 4453,8 & 4101,8 & 3757,7 & 3889,0 & 3658,0 \\
\hline 3 & 4451,2 & 3842,0 & 3828,7 & 4419,5 & 3884,3 & 4191,7 \\
\hline 4 & 3968,1 & 4156,3 & 3961,7 & 4065,5 & 3986,0 & 3610,0 \\
\hline \multicolumn{7}{|c|}{ Ganho de peso (g) } \\
\hline 1 & 2392,5 & 2411,0 & 2185,0 & 2208,0 & 2273,0 & 2208,0 \\
\hline 2 & 2626,0 & 2763,0 & 2450,0 & 2022,5 & 2127,0 & 2054,0 \\
\hline 3 & 2758,0 & 2571,0 & 2350,3 & 2619,0 & 2230,0 & 2147,5 \\
\hline 4 & 2271,0 & 2518,0 & 2294,0 & 2197,4 & 2385,0 & 2544,0 \\
\hline \multicolumn{7}{|c|}{ Conversão alimentar } \\
\hline 1 & 1,72 & 1,71 & 1,79 & 1,75 & 1,64 & 1,70 \\
\hline 2 & 1,55 & 1,61 & 1,67 & 1,86 & 1,83 & 1,78 \\
\hline 3 & 1,61 & 1,49 & 1,63 & 1,69 & 1,74 & 1,95 \\
\hline 4 & 1,75 & 1,65 & 1,73 & 1,85 & 1,67 & 1,42 \\
\hline \multicolumn{7}{|c|}{ Eficiência alimentar } \\
\hline 1 & $58 \%$ & $59 \%$ & $56 \%$ & $57 \%$ & $61 \%$ & $59 \%$ \\
\hline 2 & $64 \%$ & $62 \%$ & $60 \%$ & $54 \%$ & $55 \%$ & $56 \%$ \\
\hline 3 & $62 \%$ & $67 \%$ & $61 \%$ & $59 \%$ & $57 \%$ & $51 \%$ \\
\hline 4 & $57 \%$ & $61 \%$ & $58 \%$ & $54 \%$ & $60 \%$ & $70 \%$ \\
\hline \multicolumn{7}{|c|}{ Ganho de peso diário (g) } \\
\hline 1 & 85,45 & 86,11 & 78,04 & 78,86 & 81,18 & 78,86 \\
\hline 2 & 93,79 & 98,68 & 87,50 & 72,23 & 75,96 & 73,36 \\
\hline 3 & 98,50 & 91,82 & 83,94 & 93,54 & 79,64 & 76,70 \\
\hline 4 & 81,11 & 89,93 & 81,93 & 78,48 & 85,18 & 90,86 \\
\hline
\end{tabular}




\section{APÊNDICE L}

Análise estatística (test T) dos resultados referentes ao desempenho zootécnico de frangos de corte, linhagem Cobb, com 42 dias de vida, infectados experimentalmente com oocistos esporulados de Eimeria acervulina e submetidos a diferentes tratamentos com preparação probiótica de Lactobacillus spp..

\begin{tabular}{|c|c|c|c|c|c|}
\hline Tratamento & Média & Média & T-calculado & Grau de liberdade & $\mathbf{P}$ \\
\hline \multicolumn{6}{|c|}{ Consumo de ração(g) } \\
\hline G1CR vs. G2CR & 4152,81 & 4140,88 & 0,07 & 6 & 0,944 \\
\hline G1CR vs. G3CR & 4152,81 & 3952,31 & 1,69 & 6 & 0,142 \\
\hline G1CR vs. G4CR & 4152,81 & 4025,30 & 0,71 & 6 & 0,504 \\
\hline G1CR vs. G5CR & 4152,81 & 3873,25 & 2,40 & 6 & 0,053 \\
\hline G1CR vs. G6CR & 4152,81 & 3802,93 & 2,07 & 6 & 0,084 \\
\hline \multicolumn{6}{|c|}{ Ganho de peso(g) } \\
\hline G1GP vs. G2GP & 2511,88 & 2565,75 & $-0,41$ & 6 & 0,699 \\
\hline G1GP vs. G3GP & 2511,88 & 2319,83 & 1,56 & 6 & 0,171 \\
\hline G1GP vs. G4GP & 2511,88 & 2261,72 & 1,49 & 6 & 0,187 \\
\hline G1GP vs. G5GP & 2511,88 & 2253,75 & 2,11 & 6 & 0,080 \\
\hline G1GP vs. G6GP & 2511,88 & 2238,38 & 1,78 & 6 & 0,125 \\
\hline \multicolumn{6}{|c|}{ Conversão alimentar } \\
\hline G1CA vs. G2CA & 1,66 & 1,62 & 0,68 & 6 & 0,524 \\
\hline G1CA vs. G3CA & 1,66 & 1,71 & $-0,83$ & 6 & 0,439 \\
\hline G1CA vs. G4CA & 1,66 & 1,79 & $-2,09$ & 6 & 0,082 \\
\hline G1CA vs. G5CA & 1,66 & 1,72 & $-1,02$ & 6 & 0,345 \\
\hline G1CA vs. G6CA & 1,66 & 1,71 & $-0,45$ & 6 & 0,666 \\
\hline \multicolumn{6}{|c|}{ Eficiência alimentar } \\
\hline G1EA vs. G2EA & 0,60 & 0,62 & $-0,67$ & 6 & 0,530 \\
\hline G1EA vs. G3EA & 0,60 & 0,59 & 0,85 & 6 & 0,429 \\
\hline G1EA vs. G4EA & 0,60 & 0,56 & 2,06 & 6 & 0,085 \\
\hline G1EA vs. G5EA & 0,60 & 0,58 & 1,04 & 6 & 0,340 \\
\hline G1EA vs. G6EA & 0,60 & 0,59 & 0,29 & 6 & 0,785 \\
\hline \multicolumn{6}{|c|}{ Ganho de peso diário (g) } \\
\hline G1GD vs. G2GD & 89,71 & 91,63 & $-0,41$ & 6 & 0,699 \\
\hline G1GD vs. G3GD & 89,71 & 82,85 & 1,56 & 6 & 0,171 \\
\hline G1GD vs. G4GD & 89,71 & 80,78 & 1,49 & 6 & 0,187 \\
\hline G1GD vs. G5GD & 89,71 & 80,49 & 2,11 & 6 & 0,080 \\
\hline G1GD vs. G6GD & 89,71 & 79,94 & 1,78 & 6 & 0,125 \\
\hline
\end{tabular}

